\title{
THE ECONOMICS OF LIMITED LIABILITY: AN EMPIRICAL STUDY OF NEW YORK LAW FIRMS
}

\author{
Scott Baker* \\ Kimberly D. Krawiec**
}

Since the rapid rise in organizational forms for business associations, academics and practitioners have sought to explain the choice of form rationale. Each form contains its own set of default rules that inevitably get factored into this decision, including the extent to which each individual firm owner will be held personally liable for the collective debts and obligations of the firm.

The significance of the differences in these default rules continues to be debated. Many commentators have advanced theories, most notably those based on unlimited liability, profit-sharing, and illiquidity, asserting that the partnership form provides efficiency benefits that outweigh any costs. In this article, the authors test these theories empirically by examining the choice of organizational form by New York law firms. Although the evidence indicates a strong shift from the general partnership form to the limited liability partnership form, a significant number of New York law firms remain general partnerships.

The authors conclude that the prevailing theories based on unlimited liability, profit-sharing, and illiquidity are insufficient and posit that, in contrast to the beliefs of many commentators, the choice of form decision is quite complex. It depends on a variety of factors, including the behavior of other similarly situated firms that the decision makers consider competitors for prestige and clients. Nonetheless, it is apparent that unlimited liability is generally considered bur-

* Associate Professor of Law, University of North Carolina, email: sbaker@email.unc.edu.

** Professor of Law, University of North Carolina, email: krawiec@email.unc.edu. We thank workshop participants at Harvard, Georgetown, Fordham, Cincinnati, Wake Forest, Virginia, and Florida State University law schools and participants at the conference Uncorporation: A New Age? for helpful input on an earlier draft of this article. Gail Agrawal, Laura Beny, Bill Bratton, John Coates, John Conley, Allen Ferrell, Dan Fischel, Caroline Gentile, Mitu Gulati, Melissa Jacoby, Don Langevoort, Doug Lichtman, Tom Mroz, Mitt Regan, Larry Ribstein, Mike Seidman, Dan Tarullo, and Kathy Zeiler provided useful comments and/or contacts at New York law firms. Finally, we thank Briana Brake, Kim Garrabrant, Rachel Miles, Mike Pawlowski, and Kim Peterson for assistance in gathering the data. 
densome, and it is the authors' prediction that, at some point in time, nearly all the firms in their sample will choose to file as limited liability partnerships. The general partnership form, with its unlimited liability, will operate only as a penalty default that punishes parties who fail to sufficiently define their organization, forcing firm members to reveal relevant information to courts and interested third parties.

\section{INTRODUCTION}

The choice of organizational form for business and professional service firms has been of interest to lawyers and economists for years. The law offers a menu of choices, including general partnerships (GPs), limited partnerships (LPs), limited liability partnerships (LLPs), limited liability limited partnerships (LLLPs), limited liability companies (LLCs), and, of course, corporations. Each organizational form has its own set of default rules, governing everything from the distribution of profits to dissolution. Within each business form, parties can alter most of the default rules governing the arrangement.

One of the most important of these default rules is the extent to which individual firm owners will be held personally liable for the collective debts and obligations of the firm. GPs and corporations are considered polar opposites with respect to this default rule. The corporate default rule is one of limited liability, meaning that, absent special circumstances, corporate shareholders are personally liable for corporate debts only up to the amount of their original investment in the corporation. ${ }^{1}$ General partners, by contrast, can be held personally liable for all unpaid partnership debts. ${ }^{2}$

The significance of this difference in default rules, if any, has been hotly debated by legal academics for some time. ${ }^{3}$ In addition, both economists and legal scholars have debated the relative costs and benefits of limited liability, with some observers arguing that the owners' per-

1. The exceptions to the general rule of shareholder limited liability are that shareholders will be personally liable: (1) when the corporation is not properly formed; (2) for the amount of any unpaid capital contributions that they have committed to make; and (3) when the veil of limited liability is pierced. JeFFrey D. BAUMAN ET AL., CORPORATIONS LAW AND POLICY 318-63 (5th ed. 2003).

2. Unif. P'ship Act §§ 13-15 (1914), 6 U.L.A. (pt. I) (2001); Unif. P'ship Act §§ 304, 306 (1997), 6 U.L.A. (pt. I) (2001).

3. Compare Roger E. Meiners et al., Piercing the Veil of Limited Liability, 4 DEL. J. CoRP. L. 351, 364 (1979) (arguing that the difference in the limited liability default rule between corporations and GPs is insignificant because the default rule can be altered through a variety of private mechanisms), with, Frank H. Easterbrook \& Daniel R. Fischel, Limited Liability and the Corporation, 52 U. CHI. L. REV. 89, 93 (1985) (arguing that "the distinctive aspects of the publicly held corporationdelegation of management to a diverse group of agents and risk bearing by those who contribute capital-depend on an institution like limited liability"), and Henry Manne, Our Two Corporation Systems: Law and Economics, 53 VA. L. REV. 259 (1967) (arguing that the publicly held corporation could not exist without limited liability). 
sonal liability for the firm's debts provides efficiency benefits that outweigh any costs. ${ }^{4}$

In addition to the rule of full personal liability, many other partnership default rules appear-at least at first glance- unattractive. For example, the GP default rules include: the rule that profits and losses be split equally among the partners, the one partner/one vote rule, and the guarantee of a partner's right to seek a buyout. ${ }^{5}$

Despite these seemingly unattractive defaults, several theories have emerged regarding the desirability of the partnership form. These theories can be divided into three broad categories: (1) theories based on profit-sharing; (2) theories based on the illiquid nature of a partnership interest; and (3) theories based on the unlimited liability of the GP form. The first two categories of explanations apply to partnerships generally, whereas the third theory-unlimited liability-is a justification for the GP form, in particular.

In contrast to the theories posed by economists and legal academics that assert the benefits of unlimited liability, practicing lawyers cite the high costs of unlimited liability and argue that, given recent innovations in organizational forms, no valid reasons exist for the formation of business or professional enterprises in the GP form. ${ }^{6}$ In fact, some legal advisors go so far as to assert that any lawyer who chooses to organize clients as a GP is committing malpractice. If the practitioners are right, one must then question why the GP form exists at all.

In the last fifteen years, all fifty states have passed laws that permit the formation of an LLP. ${ }^{7}$ To become an LLP, a general partnership need only file a form with the secretary of state, pay a nominal fee, and

4. See infra text accompanying notes $23-25$.

5. Unif. P'ship Act $\S$ 401(b) (1997), 6 U.L.A. (pt. I) (2001) (default rule on profit and losses); Unif. P'ship Act \$ 401(f) (1997), 6 U.L.A. (pt. I) (2001) (default rule on management responsibilities); Unif. P'ship Act $\$ 701(a)$ (1997), 6 U.L.A. (pt. I) (2001) (default rule on partner buyouts). These default rules can be circumvented or ameliorated in several ways. First, and most obviously, the parties can opt for another organizational regime, such as the LLC or corporation. Second, the default rules other than limited liability can be altered through a detailed partnership agreement. Finally, the rule of unlimited liability can be ameliorated through contract and insurance.

6. See, e.g., Lee Berton \& Joann S. Lublin, Seeking Shelter: Partnership Structure Is Called in Question as Liability Risk Rises, WALL ST. J., June 10, 1992, at A1 (quoting Belverd Needles, former director of DePaul University's School of Accounting as stating, "With such risks, the partnership may go the way of the dodo...."); see also Jennifer J. Johnson, Limited Liability for Lawyers: General Partners Need Not Apply, 51 Bus. LAw. 85, 87 (1995) (urging law firms currently doing business in the GP form to switch to a limited liability entity); Tom Alleman, To LLP or Not to LLP: When Striking Out on Your Own, Know The Form of Business Your Practice Will Take, Legal InTELLIGENCER, Sept. 5, 2003, at 3 (2003) ("For most small groups, there really are only two choices - limited liability partnership or some form of corporation."); Sandy Lovell, Few Firms Form Limited-Liability Corporations, Inertia and Fear of Client Reaction Breed Reluctance, 163 N.J. L.J. 645 (2001) (stating that forming a limited liability entity instead of a GP should be "a no-brainer").

7. See Alan R. Bromberg \& LARry E. RibStein, Bromberg \& RibSTeIN ON Limited LiABILITY PARTNERSHIPS, THE REVISED UNIFORM PARTNERSHIP ACT, AND THE UNIFORM LIMITED PARTNERShIP ACT (2001), § 1.01(e), at 15 (2003). Some states, including New York, California, Nevada, and Oregon only offer LLP status to professional firms. Id. 
comply with a few other formalities. ${ }^{8}$ If the partners want, the old partnership agreement can continue to govern the newly formed LLP. The major difference between the GP and the LLP is that, in the LLP, the partners are liable only for debts stemming from their own conduct, or the conduct of someone under their supervision. ${ }^{9}$

The creation of the LLP form allows a natural experiment of the theories advanced regarding the costs and benefits of the partnership form. To test these theories, we collected data on the 147 law firms listed by Martindale-Hubble and the National Association for Law Placement (NALP) as having their primary offices in New York City and having more than twenty-five lawyers. ${ }^{10}$ Since 1994, all of these law firms have had the choice of whether to remain GPs or adopt LLP status. Furthermore, we supplemented the empirical analysis with extensive interviews of three sets of individuals knowledgeable about and active in the debate regarding the choice of organizational form among New York law firms: law firm partners, law firm consultants, and malpractice insurers.

If the profit-sharing or illiquidity theories of partnership fully explain the benefits of the partnership form, then all or nearly all of the firms in our sample should have opted for the LLP form, as it provides all of the same benefits of profit-sharing and lack of liquidity, without the costs of unlimited liability. In contrast, if the theories asserting unlimited liability as the primary benefit of the partnership form are true, then a majority of firms should remain GPs, or the firms should break down regarding choice of organizational form on some observable criteria.

Contrary to our expectations, a sizeable number of firms-about thirteen percent-remain GPs. Sixty-seven percent have become LLPs. ${ }^{11}$ This mix is puzzling. Overall, our analysis shows no significant variation based on number of lawyers, number of offices, rate of firm growth, level of profits, the level of collegiality, or the level of information asymmetry between the firm and its clients. Furthermore, on the surface, the difference between these firms is minimal. Each has a sophisticated practice, with sophisticated clients. They each provide roughly the same "product," namely, high-end legal services.

The movement of most firms to LLP status and the lack of a clear relationship between individual firm characteristics and choice of organizational form raise questions about the value of unlimited liability, at

8. See, e.g., N.Y. PARTNERSHIP LAW $\S 121-1500$ (McKinney 2004). In New York, a general partnership that renders professional services may become an LLP by filing a registration with the Secretary of State of New York, accompanied by a \$200 filing fee. Id. \$ 121-1500(a)-(c).

9. See BROMBERG \& RIBSTEIN, supra note $7, \S 1.02$, at 17 . States differ in the limitations on liability provided by LLP status. Some states limit liability for all claims, whether rooted in contract or tort. See id. § 1.01, at 2-17 (discussing the variations among state LLP statutes). Others states limit liability for selected types of tort claims. Id.

10. The sample also includes eight "foreign" firms whose main U.S. offices are in New York.

11. The remaining firms are PCs or LLCs. For reasons discussed in more detail in Part III, we dropped the PCs and LLCs from the analysis. 
least as applied to law firms. However, the fact that a sizeable number of firms remain GPs undermines the profit-sharing and illiquidity-based theories as the sole motivation for the partnership form as well. Because unlimited liability is the only meaningful distinction between the GP and LLP, unless many sophisticated law firms suffer from extreme inertia, it must be unlimited liability, rather than profit-sharing or illiquidity, that at least some firms perceive as valuable.

In the end, we argue that law firms today increasingly view the unlimited liability associated with the GP form as burdensome and predict that, at some point in time, nearly all the firms in our sample will file as LLPs. At the same time, however, the perceived benefits of unlimited liability are real to many law firm partners and the public assertions of many lawyers that the GP form provides no countervailing benefits to offset the costs of unlimited liability are patently inconsistent with the behavior of many large and prestigious New York law firms. We conclude, instead, that the choice of organizational form is a complicated matter, dependant on a variety of factors, including the behavior of other similarly situated firms that the decision makers consider competitors for prestige and clients.

This article proceeds as follows. Part II reviews six theories traditionally advanced as rationales for the partnership form: (1) insurance, (2) monitoring, (3) generating trust and collegiality, (4) quality signaling, (5) preventing grabbing and leaving, and (6) providing incentives to mentor.

Although there are reasons to approach many of the traditional theories of partnership form with skepticism, each yields a testable hypothesis that we examine in Part III. Subject to the caveats discussed in Part III, our data do not support any of the partnership theories introduced in Part II. To provide insight into the choice of organizational form among New York law firms, we discuss in Part IV our interviews with three sets of individuals knowledgeable about and active in that choice: law firm partners, law firm consultants, and law firm insurers. In particular, our interview data indicate that unlimited liability is increasingly viewed as a burden to be avoided, but also suggest that, for many law firm partners, the benefits of unlimited liability are real and are not necessarily outweighed by increasing liability fears. Part V concludes that the choice of organizational form is more complicated than either academic researchers or practicing lawyers have recognized.

\section{THEORIES OF PARTNERSHIP FORM}

In this part, we discuss six theories advanced by researchers to justify the partnership form. Each of these theories is dependent on one of three characteristics associated with partnerships: profit-sharing, a characteristic of both GPs and LLPs; illiquidity, a characteristic of both GPs 
and LLPs; and unlimited liability, a characteristic of the GP, but not the LLP.

As we elaborate throughout this section, there are reasons to doubt the explanatory power of many of the traditional theories. For example, contrary to the assumptions of many economists, profit-sharing is not a unique characteristic of the partnership form and can be easily accomplished through an LLC or corporation, albeit with greater transaction costs in the case of the corporation. In addition, illiquidity is a common characteristic of both LLCs and close corporations and, through the use of standard-form restrictions on resale, these investments can be made just as illiquid as the partnership interest. Nonetheless, we test each of these theories of partnership form in the following Part III of this article.

\section{A. Insurance}

The insurance theory of partnership form is based on the perceived efficiency benefits of profit-sharing and is frequently invoked to explain the tendency of professionals to organize as partnerships. The insurance theory starts by noting that professionals make a significant investment in human capital. ${ }^{12}$ Such investment is hard to diversify and, hence, risky. Furthermore, an insurance market for human capital does not exist because of moral hazard and adverse selection. Consider a lawyer who invests heavily to become a skilled bankruptcy attorney. The return on the lawyer's investment is linked to the demand for bankruptcy work. If, for instance, there is a prolonged economic boom, the return on the lawyer's investment is small. The lawyer cannot mitigate this risk through insurance, because any insurer-fearing moral hazard on the part of the attorney-would feel uncomfortable writing a policy that paid out when an attorney's business was slow.

The question becomes, then, how can the bankruptcy attorney insulate herself from risk. According to some economists, she teams up and forms a partnership with other attorneys. The partnership allows the attorney to share profits with attorneys in different areas. Through profitsharing, the attorneys diversify their individual investments in human capital. Moral hazard remains a problem, however, because one partner might shirk, knowing that she will still recoup income through the profitsharing arrangement. Nonetheless, economists argue that the partners in a professional firm are better able to monitor (and therefore control) moral hazard than outside insurers.

For the sake of analysis, we accept the premises of the insurance theory of partnership that profit-sharing is useful because it reduces the

12. For formal articulations of the insurance theory of partnership, see Martin Gaynor \& Paul Gertler, Moral Hazard and Risk Spreading in Partnerships, 26 RAND J. ECON. 591 (1995); Kevin Lang \& Peter-John Gordon, Partnerships as Insurance Devices: Theory and Evidence, 26 RAND. J. Econ. 614 (1995). 
risk of human capital investment and partners are better than outside insurers at controlling moral hazard. From these premises, however, the choice of partnership form does not inevitably follow. A corporation, LLC, or PC could all share profits in the same way as a partnership. Although such profit-sharing arguably entails higher transaction costs in the corporate form, it is not clear that those costs outweigh the benefits of limited liability provided by the corporate form.

Nonetheless, as discussed in Part III of this article, an examination of New York law firms after the passage of the LLP statute allows at least a partial test of the insurance theory of partnership. If the insurance theory fully explains the advantages associated with the partnership form, ${ }^{13}$ then all or nearly all of the firms in our sample should be LLPs, ${ }^{14}$ because the LLP provides all of the insurance benefits associated with partnerships without the associated costs of unlimited liability inherent in the GP form.

\section{B. Monitoring Fellow Partners}

The monitoring theory of partnership takes two different forms, one based on profit-sharing and the other based on unlimited liability.

\section{Profit-Sharing and Monitoring}

In an early article on this subject, Armen Alchian and Harold Demsetz proposed that employee ownership and profit-sharing are useful when it is hard to monitor each employee's input in the production process. ${ }^{15} \mathrm{By}$, in effect, making each employee a residual claimant on profits, the employee-owned firm with profit-sharing induces monitoring of each employee by every other employee. ${ }^{16}$ The inability to monitor an individual employee's input, Alchian and Demsetz claim, is the reason why many professional firms are employee-owned partnerships. ${ }^{17}$

13. As an empirical matter, the observed break-down among New York firms allows us only to reject the illiquidity and profit-sharing theories as the sole rationale behind the choice of organizational form among New York law firms. However, as discussed supra notes 10-11 and accompanying text, our interview data, combined with the fact that the partnership form does not provide unique profit-sharing or illiquidity benefits, cause us to doubt that the illiquidity or profit-sharing based theories of partnership are even a contributing factor, much less the sole factor, that explains the benefits of the partnership form.

14. Although, in theory, if the insurance explanation fully explains the choice of organizational form, all firms in our sample should be LLPs, we phrase the hypothesis as all or nearly all andwithout more-would not reject the insurance theory of partnership if we were to observe a few firms still clinging to the GP form. This is because, in reality, there is always a possibility that inertia, lack of attention, or transaction costs prevent a handful of firms from adopting the ideal organizational form.

15. Armen A. Alchian \& Harold Demsetz, Production, Information Costs, and Economic Organization, 62 AM. ECON. REV. 777 (1972).

16. Id. at $785-86$

17. Id. at 786. Henry Hansmann argues that Alchian and Demsetz overstate the monitoring problem associated with professional work. Hansmann points out that professional firms go to great lengths to figure out how much each partner adds to the final product by, for example, tracking bill- 
More recently, Eugene Kandel and Edward P. Lazear have argued that peer pressure can produce higher effort among a firm's members. ${ }^{18}$ Because firm members are more likely to apply pressure on other firm members to perform when they empathize with those whose income they affect-i.e., the firm's stakeholders-peer pressure is more likely to be an effective motivating device in firms in which profits are shared among similarly situated individuals. ${ }^{19}$ Accordingly, partnerships are more likely to produce higher peer pressure and induce higher effort levels than are firms that are not organized for profit-sharing.

As with the insurance theory of partnership, we accept the premise of the monitoring theory that profit-sharing is desirable for the sake of analysis. Yet the choice of partnership form does not inevitably follow from this premise. As widely discussed in the worker cooperative literature, the monitoring explanation is an argument in favor of employee ownership rather than investor ownership of firms. ${ }^{20}$ Nonetheless an employee-owned firm does not have to be a partnership. The close corporation and LLC are also typically employee-owned entities in which the residual claimants on profits are directly involved in management.

Nonetheless, we test the profit-sharing based monitoring theory of partnership in Part III of this article. If profit-sharing through the partnership form fully explains the benefits associated with partnership, then all or nearly all of the firms in our sample should have adopted LLP status, as it provides all of the profit-sharing benefits of the GP form without the associated costs of full personal liability. ${ }^{21}$

able hours. In addition, Hansmann notes that most profit-sharing agreements reflect the individual productivity of each partner. HENRY HANSMANN, THE OWNERSHIP OF ENTERPRISE 70-71 (1996); see also George Rutherglen \& Kevin A. Kordana, A Farewell To Tournaments? The Need for an Alternative Explanation of Law Firm Structure and Growth, 84 VA. L. REV. 1695, 1697-98 (1998) (making a similar argument). Others, however, have challenged Hansmann on this point, arguing that monitoring the work-product of professional service providers such as lawyers is not as easy as Hansmann suggests. See, e.g., David B. Wilkins \& G. Mitu Gulati, Reconceiving the Tournament of Lawyers: Tracking, Seeding, and Information Control in the Internal Labor Markets of Elite Law Firms, 84 VA. L. REV. 1581, 1598-99 (1998).

18. Eugene Kandel \& Edward P. Lazear, Peer Pressure and Partnerships, 100 J. PoL. ECON. 801, 805 (1992) (noting that, although peer pressure guarantees higher effort level, it does not guarantee higher utility, as peer pressure itself is a cost borne by the firm's members).

19. Id. at 816 .

20. See Gregory Dow, Governing The Firm: ECONOMIC THEORY AND Worker CONTROL (2003) (discussing evidence on the question of whether worker-run enterprises engage in better monitoring); Avner Ben-Ner, The Life Cycle of Worker-Owned Firms in Market Economies, $10 \mathrm{~J}$. ECON. BEHAV. \& ORG. 287, 293-94 (1988) (asserting that better monitoring will occur at worker-run firms); Henry Hansmann, When Does Worker Ownership Work? ESOPs, Law Firms, Codetermination, and Economic Democracy, 99 YALE L.J. 1749, 1762-63 (1990) (discussing, but rejecting, the argument that worker control and participation arise primarily to resolve the monitoring problem).

21. See infra note Part III.B.3.b.i (explaining this hypothesis in more detail). 


\section{2. $\quad$ Unlimited Liability and Monitoring}

Another version of the monitoring theory asserts that unlimited liability encourages monitoring of each partner by every other partner. ${ }^{22}$ In the event of another partner's misstep, a partner does not want to be on the hook for any award in excess of the partnership's assets and insurance coverage. Accordingly, under this version of the monitoring theory, unlimited liability induces each partner to pay close attention to the activities of her fellow partners. As a result, effort and care are maximized, resulting in a better product.

Because the ease and effectiveness of monitoring are likely to be a function of the number of offices (geographic dispersion), the number of lawyers (firm size), and the firm's rate of growth, the monitoring hypothesis suggests that the regression results will reveal a statistically significant effect of the number of lawyers variable (LAWYERS), the number of offices variable (OFFICES), and the rate of growth variable (GROWTH) on the choice of organizational form. ${ }^{23}$ In addition, because the unlimited liability version of the monitoring theory asserts that partners of LLPs monitor the quality of the firm's output less vigilantly than do partners of GPs, it suggests that LLPs provide an inferior legal product. If this is the case, and if clients possess some knowledge about the quality of legal services provided by law firms, then law firms that are LLPs must either: (1) charge less for the provision of legal services than would the same firm if it had remained a GP; or (2) charge the same amount, but lose clients to firms that price legal services in accordance with quality.

Accordingly, if the unlimited liability version of the monitoring theory is true, the empirical and interview data should reveal that either: (1) firms that opted for LLPs status were forced to reduce their billing rates, or (2) firms that opted for LLP status experienced less revenue growth (that is, firms that become an LLP experience significant, abnormal, de-

22. Larry E. Ribstein, Ethical Rules, Agency Costs, and Law Firm Structure, 84 VA. L. REV. 1707, 1728 (1998) (stating that "unlimited liability, by substituting for reputational and financial capital, arguably provides an important assurance to clients that law firms will discipline shirking and other selfinterested conduct of their members").

23. Kandel \& Lazear, supra note 18, at 812-13 (demonstrating that both the effectiveness of and the incentive to engage in monitoring decrease with increases in firm size and geographic dispersion). We did not predict whether this effect should be positive or negative, because we were unsure of the direction in which size, geographic dispersion, and rate of growth should impact the choice of whether to become an LLP. One might surmise that large firms, geographically dispersed firms, and quickly growing firms find it more difficult to monitor and, therefore, choose to remain GPs in order to induce each partner to monitor every other partner. In this case, we would predict a negative relationship between the variables LAWYERS, OFFICES, and GROWTH and the likelihood that a firm is an LLP. Alternatively, one might imagine that large firms, quickly growing firms, and geographically dispersed firms find it so difficult to monitor that remaining GPs in the hopes of inducing more monitoring is pointless. In such a case, the LLP liability shield should be more attractive and such firms should be more likely to form LLPs. Under this scenario, we would predict a positive relationship between the variables LAWYERS, OFFICES, and GROWTH and the probability that the firm is an LLP. 
creases in profits per partner (PROFITS) that the firm would not have experienced if the firm had remained a GP). In addition, if LLPs are actually producing an inferior legal product, then their risk of malpractice liability should be higher and, as a result, their insurance premiums should be higher than they would be if the firm had remained a GP. As such, the interview data should reveal that law firms that are LLPs pay higher liability insurance premiums than if they had opted to remain a GP.

\section{Generating Trust and Collegiality}

A third theory of partnership form involves bonding and the creation of trust among partners. A partner, the theory goes, signals trust in her fellow partners by agreeing to personal liability for their actions. This trust creates a more congenial work environment, enhancing the quality of the product.

At first glance, the trust theory of partnership-because of its reliance on the unique unlimited liability characteristic of the GP formseems a plausible explanation for the choice of GP form. However, as noted in the debate regarding the benefits of limited liability, the GP form is not the only mechanism for placing an owner's personal wealth at stake in a business or professional enterprise. ${ }^{24}$

Nonetheless, we test the collegiality hypothesis in Part III of this article. Because larger groups, more geographically dispersed groups, and quickly growing groups are typically considered less collegial than small, stable, closely-knit groups,${ }^{25}$ the collegiality hypothesis suggests that the regression results will reveal a statistically significant effect of LAWYERS, OFFICES, and GROWTH on the choice of organizational form.

In addition, law firms that have multi-tiered partnership structures (TIER) are considered less collegial than those firms in which partners are treated equally. ${ }^{26}$ As a result, one might expect that firms with a

24. For example, the partners could form a limited liability entity, but personally guarantee debts. They could also post personal bonds, or over-capitalize the corporation, rather than withdrawing funds in excess of that needed for working capital. See, e.g., Easterbrook \& Fischel, supra note 3 , at 103-04 (arguing that voluntary corporate creditors frequently require personal guarantees or use other mechanisms to alter the default rule of limited liability for shareholders); Henry Hansmann \& Reinier Kraakman, The Essential Role of Organizational Law, 110 YALE L.J. 387, 429-30 (2000); Amalia D. Kessler, Limited Liability In Context: Lessons from the French Origins of the American Limited Partnership, 32 J. LEGAL STUD. 511, 546 (2003).

25. See generally Robert Ellickson, Order Without Law: How Neighbors Settle DisPUTES (1991) (discussing the role of extra-legal, collective norms in small, closely-knit groups); Mancur Olson, The Logic of Collective ACTION (1971) (demonstrating that coordination and the resolution of collective action problems are more difficult for larger groups); Christopher R. Leslie, Trust, Distrust, and Antitrust, 82 TEX. L. REV. 515, 535-37 (2004) (discussing trust and cooperation).

26. See Elizabeth H. Gorman, Moving Away From "Up or Out": Determinants of Permanent Employment in Law Firms, 33 LAW \& SOC'Y REV. 637, 646 (1999) (noting that "[i]n a collegial organi- 
multi-tiered partnership structure value collegiality less, and hence are less likely to remain a GP in an effort to maintain firm collegiality. Therefore, the collegiality hypothesis suggests that the regression results will reveal a statistically significant positive effect of the TIER variable on the likelihood that a firm is an LLP.

Finally, some law firms publicize their collegial environment, whereas others do not. If the collegiality theory of partnership is true, we should observe a statistically significant negative effect of the COLLEGIAL variable on the probability that a law firm chooses to become an LLP. ${ }^{27}$

\section{Quality Signaling}

The signaling theory of partnership takes two different forms, depending on the source of the signal. In the initial formulation, firms signal quality by adopting unlimited liability. In the more recent articulation, profit-sharing serves as the signal. According to the quality signaling theory, the need for signaling arises whenever consumers are unable to assess the quality of a product. As a result, they are reluctant to buy the product without some quality assurance.

\section{Unlimited Liability and Signaling}

One version of the quality signaling theory asserts that unlimited liability encourages each partner to take more care in the provision of goods and services in order to avoid losing personal assets. In addition, as discussed in Part II.B.2, unlimited liability is thought to encourage monitoring of each partner by every other partner. Knowing these facts, consumers feel more comfortable about the quality of the product. In other words, unlimited liability is thought to provide a credible signal of quality.

There are reasons to approach the quality signaling theory with skepticism. Although unlimited liability might serve as a quality signal, it is not the only possible signal of quality. For example, a firm can also signal quality by maintaining a good reputation, established through repeated interactions with consumers. For unlimited liability signaling to work, one must demonstrate that unlimited liability is the cheapest credible signal of quality.

Despite this skepticism, we test the unlimited liability version of the quality signaling theory in Part III of this article. Because the quality

zation, ... all are formally equal in status"); $i d$. at 650-51 (finding that collegiality, as measured by firms' narrative descriptions, is negatively associated with the presence of a two-tier partnership structure); Peter D. Sherer, Leveraging Human Assets in Law Firms: Human Capital Structures and Organizational Capabilities, 48 InDUS. \& LAB. REL. REV. 671, 677 (1995) ("[T]iers may damage the sense of collegiality and mutual monitoring that exists when partners are coequals.").

27. See infra notes $77-86$ and accompanying text (describing this variable in more detail). 
signaling theory depends on information asymmetry between producers and consumers of products (in this case, legal services), we predict that firms whose clients possess less information regarding the quality of legal services they receive should have a greater need to engage in this type of quality signaling than firms whose clients are well-informed regarding the quality of legal services they purchase. Because more sophisticated clients are more likely to possess such information and because clients in the Fortune 250 are more likely to be sophisticated than clients that are not, we predicted a significant, positive effect of the Fortune 250 variable (FORTUNE) on the probability that the firm is an LLP. ${ }^{28}$

In addition, because research shows that more sophisticated clients and clients with a higher number of in-house counsel are more informed about the quality of legal services provided by law firms, ${ }^{29}$ this version of the signaling hypothesis suggests that the logit model results will reveal a statistically significant positive effect of both the average and the total number of in-house counsel (IN-HOUSE-AVG and IN-HOUSETOTAL) and the Fortune 250 variable (FORTUNE) on the probability that a firm is an LLP. ${ }^{30}$ Finally, if becoming an LLP really sends a negative signal to clients about the quality of legal services, then firms that become an LLP should either: (1) charge less for legal services than they otherwise could if the firm had remained a GP; or (2) see a significant, abnormal, negative change in profits-per-partner (PROFITS) that the firm would not have experienced if it had remained a GP.

\section{Profit-Sharing and Signaling}

Jonathan Levin and Steven Tadelis advance a different signaling theory of partnership, focusing on profit-sharing. ${ }^{31}$ They start with the notion that an employee-owned firm engaged in profit-sharing is less inclined than a corporation to hire new workers. ${ }^{32}$ In a profit-sharing partnership, each partner cares about profits per partner, not total profits. As a result, a new partner will not be welcomed into the firm unless her contribution to firm profits is greater than the profits produced by the average partner. In contrast, because a corporation cares about total

28. Cf. Abram Chayes \& Antonia H. Chayes, Corporate Counsel and the Elite Law Firm, 37 STAN. L. REV. 277, 290-93 (1985) (discussing the important role of in-house counsel in monitoring and selecting outside counsel, especially at the largest American corporations); John C. Coates IV, Explaining Variation in Takeover Defenses: Blame the Lawyers, 89 CAL. L. REV. 1301, 1310 n.40 (2001) ("Older, larger, and more profitable companies are more likely to have better and larger in-house legal staffs more capable of monitoring outside firms.").

29. Robert L. Nelson, Partners with Power: The Social Transformation of the LARGE LAW FIRM 59 (1988); see also Mark C. Suchman, Working Without a Net: The Sociology of Legal Ethics in Corporate Litigation, 67 FORDHAM L. REV. 837, 856 (1998).

30. See infra notes 50, 61-62 and accompanying text (describing these variables).

31. Jonathan Levin \& Steven Tadelis, Profit-Sharing and the Role of Professional Partnerships, at (Stanford Inst. for Econ. Policy, Research Paper No. 03-031, 2004), http://ssrn.com/abstract=500322 ("We take the defining feature of a partnership to be redistribution of profits among partners.").

32. Id. 
profits, it will bring in new workers if the marginal benefit of that worker is greater than their marginal cost to the firm. Because the partnership focuses on average profits rather than the marginal increase in profits, a profit-sharing partnership has an incentive to hire higher quality workers than the corporation. ${ }^{33}$

In markets where there are informational disparities, however, both the corporation and the partnership have an incentive to hire less able workers, hoping that the consumer will fail to notice the resulting loss in quality. Levin and Tadelis conclude that the incentive to "cheat" on worker quality is mitigated in a partnership because of the partnership's initial preference for higher quality workers. ${ }^{34}$ They argue that this explains why professional firms are more apt than other types of firms to organize as partnerships: the market for professional services (for example, law, medicine, or accounting) contains large informational disparities, making the choice of the partnership form more profitable. ${ }^{35}$

As previously discussed in Parts II.A and B of this article, the partnership form is unnecessary to attain the benefits of profit-sharing. As a theoretical matter, we thus find it unlikely that any partnership theory based on profit-sharing, including signaling theories, can account for the choice of organizational form among New York law firms. Nonetheless, we test the profit-sharing version of the quality signaling theory in Part III of this article. If Levin and Tadelis are correct that the partnership form signals profit-sharing to customers, and if this fact fully explains the benefits provided by the partnership form, then all or nearly all of the firms in our sample should be LLPs, as the LLP provides all of the profitsharing benefits of the partnership form without the accompanying costs of unlimited liability necessitated by the GP form. ${ }^{36}$

\section{E. Preventing "Grabbing and Leaving"}

According to the grab and leave theory of partnership, certain types of businesses-specifically, the practice of law-benefit from an up or out system of partnership. ${ }^{37}$ This is because, over time, attorneys develop client-specific assets in the form of knowledge and expertise in the han-

33. Levin and Tadelis demonstrate that this is not always an optimal result. If there is no asymmetric information in the market, the partnership operates inefficiently. It hires workers of too high a quality and provides too high a quality of product. Id. at 16 . Put another way, in the "fullinformation" market consumers prefer to pay less and receive a lower quality product than the profitsharing partnership produces.

34. Id. at 12

35. This is the essence of proposition 3 in their paper. Id. at 13.

36. See supra note 9 and accompanying text (describing this hypothesis in more detail).

37. See, e.g., Marc Galanter \& Thomas Palay, Tournament of Lawyers: The Transformation OF THE BIG LAW FIRM (1991); Ronald J. Gilson \& Robert H. Mnookin, Sharing Among the Human Capitalists: An Economic Inquiry into the Corporate Law Firm and How Partners Split Profits, 37 Stan. L. ReV. 313, 315 (1985); James B. Rebitzer \& Lowell J. Taylor, When Knowledge Is an Asset: Explaining the Organizational Structure of Large Law Firms (working paper) (on file with authors). 
dling of specific clients. This expertise gives senior lawyers significant power over their employers. By threatening to "grab" their clients and leave the firm, these lawyers can extract a higher share of the firm's profits.

To prevent senior lawyers from "grabbing" their clients and leaving the firm, law firms developed the up or out system of partnership in which associates are either fired before they get a chance to develop a relationship with clients or are promoted to residual claimants on the firm's assets. ${ }^{38}$ This system is more important in law firms than in conventional firms because law firms lack the ability to establish property rights in client-specific knowledge.

The partnership structure effectively eliminates the defection of partners, by maximizing profits per partner, rather than total profits. ${ }^{39}$ According to Rebitzer and Taylor, only under the partnership structure can senior attorneys be paid enough to prevent them from grabbing and leaving with the firm's clients because the partnership structure results in higher profits per partner, even though the corporation results in higher total profits. ${ }^{40}$

The Rebitzer and Taylor theory, however, is not a convincing explanation of the benefits of the partnership form. Rebitzer and Taylor assume that corporations are, by definition, entrepreneur-owned firms and that partnerships are, by definition, employee-owned firms. ${ }^{41} \mathrm{Be}-$ cause employee-owned firms are more profitable under certain circumstances that are important to professional firms, many economists believe that this fact explains the prevalence of the partnership structure among professional firms and the prevalence of the corporate structure among industrial firms. However, neither corporations nor LLCs are necessarily entrepreneur-owned firms. In fact, it is quite common in close corporations and small LLCs to see a complete overlap of ownership and management, as is the case in a partnership.

Nonetheless, we test the grab and leave hypothesis in Part III of this article. The LLP and GP are identical in the extent to which they foster profit-sharing and would thus equally prevent grabbing and leaving. Accordingly, if the grab and leave theory fully explains the advantages of partnership relative to other organizational forms, then all or nearly all of the firms in our sample should be LLPs because the LLP provides all

38. The firm is unable to write enforceable contracts that effectively prevent grabbing and leaving due to the ABA Model Rules, which prohibit contracts that limit a client's freedom to choose her lawyer. See Model Rules of Prof'L CONDuct R. 5.6 (2004); Robert W. Hillman, Organizational Choices of Professional Service Firms: An Empirical Study, 58 Bus. LAw. 1387, 1388-89 (2003); Rebitzer \& Taylor, supra note 37.

39. Rebitzer \& Taylor, supra note 37 , at 10.

40. Id. at 12

41. Id. 
of the benefits of profit-sharing without any of the GP's associated costs stemming from unlimited liability. ${ }^{42}$

\section{F. Incentives to Mentor}

One of the more creative justifications for the partnership form involves mentoring. ${ }^{43}$ The mentoring theory begins from the premise that much professional work requires the development of human capital and many professionals require mentoring in order to enhance their skills. The junior associate, for instance, needs a senior partner to teach her how to conduct a trial or close a deal. As the professional ages, however, she has an incentive to horde her knowledge and avoid mentoring new entrants to the profession. She would prefer to take her knowledge and leave the firm, keeping all of the benefits of her knowledge to herself. Partnerships, however, are relatively illiquid forms of investment, making exit difficult. To maintain a pool of skilled workers to promote, the senior professional engages in mentoring. This mentoring is profitable because it increases the return on the partner's illiquid investment in the partnership.

Mentoring is not a wholly satisfactory explanation for the existence of partnership and almost certainly fails to explain the choice of organizational form among New York law firms. Close corporations, LLCs, and LLPs also represent relatively illiquid investments. In fact, such investments can be made just as illiquid as a partnership interest through the use of fairly routine restrictions on the transfer of interests. In addition, although the partnership default rules create an illiquid investment, as an empirical matter most partnership agreements have buyout provisions ameliorating this effect. ${ }^{44}$

Nonetheless, we test the mentoring theory in Part III of this article. Because there is no liquidity difference between the GP and LLP (in fact, a firm that files for LLP status need not alter the underlying GP agreement, leaving any buyout provisions completely unaltered), if mentoring fully explains the advantage of the partnership relative to other organizational forms, then all or nearly all of the firms in our sample should be LLPs. This is because, like all of the partnership theories based on illiquidity or profit-sharing explanations, the LLP provides all of the purported benefits of the GP, without the accompanying costs of unlimited liability. ${ }^{45}$

42. See supra note 37 and accompanying text (explaining this hypothesis in more detail).

43. See Alan Morrison \& William J. Wilhelm, Jr., Partnership Firms, Reputation and Human Capital Oxford Fin. Research Center, Working Paper No. 2003-FE-02, 2003), http://ssrn.com/ abstract $=373440$.

44. See Larry E. Ribstein, Why Corporations?, 1 BERKELEY BUS. L.J. 183, 195 (2004).

45. See supra note 9 and accompanying text (explaining this hypothesis in more detail). 


\section{EMPIRICAL ANALYSIS}

\section{A. Data Collection}

To explore the choice and determinants of organizational form, we collected data on the choice of organizational form among New York law firms - that is, law firms listing New York City as their primary officewith more than twenty-five lawyers. ${ }^{46}$ We limited our study to New York City firms for a variety of reasons. ${ }^{47}$ By restricting our sample to firms in a particular region, we were able to minimize variations in the choice of organizational form based on geographic or cultural differences, differences in the state legal regime or ethics code, and differences in state and local tax codes. ${ }^{48}$

Under the supervision of the two authors, research assistants collected most of the data. The data, along with a detailed memo describing the collection process, are publicly available at http://www.law.unc.edu/ data/economicsoflimitedliability.

There are 147 firms in the sample. We used seven sources to build the dataset: (1) Martindale-Hubble, both print and web versions; (2) NALP, both print and web versions; (3) filings from the New York Secretary of State; (4) the list of profits per partner for the top 200 law firms published by the American Lawyer; (5) American Lawyer Media, Cor-

46. We did not study law firms with fewer than twenty-five attorneys. These small firms may differ from their larger counterparts in ways that significantly affect their choice of organizational form, rendering them poor subjects for our study. For example, very small firms could differ from large firms in terms of culture, practice area, and the impact of various laws (such as the New York City tax on LLPs). In addition, a small association of lawyers may be less a "firm" than a grouping of lawyers that share office space and resources, but lack a common goal, history, and culture. See Bruce M. Price, How Green Was My Valley? An Examination of Tournament Theory as a Governance Mechanism in Silicon Valley Law Firms, 37 LAw \& SOC'Y REV. 731, 742 (2003) (excluding law firms of fewer than ten lawyers from an empirical study of Silicon Valley firms for similar reasons).

47. Bob Hillman, who constructed a nationwide database of law firms, has done the other major empirical study examining the choice of organizational form by law firms. See Hillman, supra note 38, at 1397-1403. Although a welcome addition to the literature, Hillman does not use the data to test the economic theories concerning partnerships. Eric Talley and John Romley also conduct a major nationwide empirical study. John Romley \& Eric Talley, Uncorporated Professionals (CLEO Research Paper Series No. C0418, 2004). We discuss their results infra note 77.

48. For example, converting from a PC to an LLP has significant negative tax consequences. Johnson, supra note 6, at 85 n.19 ("While a PC may also convert to an LLC or an LLP, there are significant tax impediments to such a conversion in that it will be treated as a liquidation under I.R.C. $\S 336$ (1988).”). In addition, many firms in states whose PC statute (unlike New York's) provided an advantageous liability shield converted from GPs to PCs some time ago. As a result, these firms are effectively prohibited from filing as an LLP, even if they might desire to do so. Similarly, in some jurisdictions, local tax codes may affect the choice of organizational form. For example, both New York City and New York State tax PCs more heavily than partnerships. See Terrence A. Oved, New York State Limited Liability Partnerships, 67 N.Y. ST. B.J., Mar.-Apr. 1995, at 38, 39 (noting that "[g]eneral partnerships do not pay... state tax on their profit but rather a $4 \%$ unincorporated business tax to New York City" and "a law firm organized as a professional corporation must make an annual tax payment of up to $1.8 \%$ and approximately $9 \%$ of its net income, respectively, to New York State and New York City"). Presumably because of these tax considerations, as well as the fact that New York's PC statute is not a superior liability shield to the LLP, only two firms filed for PC status after the LLP statute was enacted. 
porate Counsel Division, Directory of In-House Law Departments at the Top 250 Companies (The Directory of In-House Departments), ${ }^{49}$ (6) individual law firm websites; and (7) telephone conversations with selected law firms to verify or clarify certain information. We then supplemented this empirical data with a series of interviews of individuals active in and knowledgeable about the choice of organizational form by New York law firms.

\section{Number of Lawyers (LAWYERS), Number of Offices (OFFICES), and Growth Rate (GROWTH)}

Martindale-Hubble and NALP provided firm names, number of lawyers (LAWYERS), number of offices (OFFICES), choice of organizational form (FORM), and was used to calculate each firm's growth rate (GROWTH). We verified the Martindale-Hubble and NALP information through the New York Secretary of State's office, by consulting firm websites and, in a few cases, by calling the firm's offices to verify information that remained unclear after consulting the website.

LAWYERS is the total number of attorneys at each firm in 2004. OFFICES is the total number of each firm's separate offices in 2004. LAWYERS and OFFICES were collected from the Martindale-Hubble website. $^{50}$ OFFICES was then cross-checked against each firm's website. $^{51}$

GROWTH is the yearly percentage change in each firm's total number of attorneys, averaged from 1994-2003.52 For reasons detailed below, GROWTH was calculated using two sources: the print versions of NALP and Martindale-Hubble. This calculation was done by dividing the firms into three categories: (1) firms that NALP listed in every year for the period 1994-2003; (2) firms that NALP did not list for any year

49. A searchable version of The Directory of In-House Departments is available at http:// solis. 365 media.com/alm/search.asp?cat $=987223$. The Directory of In-House Departments includes information collected and printed in the November issue of American Lawyer Media's Corporate Counsel magazine in the article entitled Who Represents America's Biggest Companies?, as well as additional biographical data that was independently compiled by American Lawyer Media's Corporate Counsel Division. We compiled a list of the number of each firm's Fortune 250 clients, if any, and the number of in-house counsel employed by those clients by searching the directory in May 2004.

50. The homepage for Martindale-Hubble is $\mathrm{http}: / / \mathrm{martindale.com} / \mathrm{xp} / \mathrm{Martindale} / \mathrm{home} . \mathrm{xml}$.

51. When the number of offices listed on the firm's website conflicted with the number of offices provided by Martindale-Hubble, we used the number of offices listed on the firm's website. Both the Martindale-Hubble search and the website cross-checks were conducted in March 2004.

52. Except as otherwise noted, we include within the attorney count for GROWTH all firm members with a J.D. degree, including partners, associates, counsel, and of counsel, but did not include retired partners. We include individuals regardless of whether the individual has been admitted to a bar or whether bar passage is still pending. Data on the number of lawyers are not available for all firms for every year between 1994 and 2003. In such cases, GROWTH is the average growth rate for the subset of years for which growth data are available. 
during the period 1994-2003; and (3) firms that NALP listed in some years during the period 1994-2002, but not in others. ${ }^{53}$

For a variety of reasons, NALP is both a more reliable and more user-friendly source for calculating law firm growth rates. ${ }^{54}$ Accordingly, we used NALP to calculate GROWTH whenever possible.

For the first category of firms (those listed in NALP every year for the period 1994-2003), we used NALP data for every year. ${ }^{55}$ For the second category of firms (those that NALP did not list for any year during the period 1994-2003), we used Martindale-Hubble data for every year. ${ }^{56}$

For the third category of firms (those listed in NALP for some years, but not for others), we compared the available NALP data to the Martindale-Hubble data for any missing NALP years and determined whether the Martindale-Hubble data followed the yearly trend in growth rates calculated from the NALP data. If consistent, we used the Martindale-Hubble data for the years the firm was not listed in NALP. If inconsistent, we disregarded the previously collected NALP data and recalculated the firm's growth rate using Martindale-Hubble data for every year.

\section{Organizational Form (FORM), Filing Date (DATE), Whether the Firm Is Domestic or Foreign (FOREIGN), and Designation of New York City as the Firm's Main Office}

We verified each firm's organizational form (and, for firms that were organized as LLPs, LLCs, or PCs, collected filing date information)

53. Due to inconsistencies and apparent errors in reporting by NALP and/or Martindale-Hubble during the time frame of our study, various firm-specific decisions were made about how certain information on GROWTH would be treated. These decisions are detailed in a memo available on our website at http://www.law.unc.edu/data/economicsoflimitedliability.

54. For example, NALP provides information on firm demographics that includes the number of lawyers (although, as discussed infra note 55, this number is sometimes a firmwide number and at other times an officewide number). In contrast, Martindale-Hubble lists lawyers within a firm by name and does not provide a total number, thus increasing the likelihood of error caused when individual names (in some cases, more than 1000) must be counted by hand. Furthermore, MartindaleHubble sometimes lists all of the firm's lawyers under the heading for the New York office. At other times, it lists only the New York lawyers under this heading. As a result, every office for every firm must be cross-checked against every other office for that firm to determine whether lawyers have been double-listed under both New York and a branch office.

55. NALP lists each firm's number of attorneys under "Firm Demographics." Sometimes this number represents each attorney employed by the firm. At other times, it represents only the number of attorneys in the New York office. When the "Firm Demographics" listed only the New York attorneys, attorneys from other offices were added in from the firm's "Narrative Description" or from the "Other Offices" category.

56. See supra note 54. To calculate GROWTH from Martindale-Hubble, we had to hand-count the attorneys that were listed by name in every office for each firm. On some occasions, MartindaleHubble did not list associates, but instead listed only partners, counsel, and of-counsel. In order to maintain a consistent counting method for each firm across time, if the firm did not list associates in any single year, we did not count associates - even if they were listed-in any other year. 
from filings with the New York Secretary of State's office. ${ }^{57}$ We considered a firm's main office to be located in New York City if the Martindale-Hubble website designated the New York City office as the firm's "main office." If Martindale-Hubble reported a firm as having multiple main offices, we concluded that the firm's main office was in New York City, so long as one of the main offices was located in New York City.

FOREIGN indicates those firms headquartered outside of the United States, but who report to Martindale-Hubble that their main United States office is located in New York City. All main office results were cross-checked against each individual firm website. If the individual website conflicted with the designation in Martindale-Hubble, we listed the main office as it appeared on the firm's website. ${ }^{58}$

\section{Profits Per Partner (PROFITS)}

The American Lawyer magazine provided the partner profit data. American Lawyer has two series of profit data. One series reports profits per partner on the 100 most profitable firms in the United States (the AmLaw 100). A second series, the AmLaw 200, provides profit data on the "second 100"-firms that rank between 101 and 200 in terms of profitability. ${ }^{59}$ Thirty-six firms in the sample are among the 200 most profitable law firms in the country.

\section{Average Number of In-House Counsel (IN-HOUSE-AVG), Total Number of In-House Counsel (IN-HOUSE-TOTAL), and Number of Clients in the Fortune 250 (FORTUNE)}

The number of a firm's clients in the Fortune 250 was used as a proxy for client sophistication and, thus, for the level of information asymmetry between lawyer and client. The theory behind the FORTUNE variable is that firms that have more clients in the Fortune 250 have clients who are more informed regarding the quality and pricing of legal services than do law firms with fewer numbers of clients in the Fortune 250. As a result, there is a lower level of information asymmetry

57. We gathered this information in March 2004, from a searchable website maintained by The New York Department of State. The website is located at http://appsext5.dos.state.ny.us/corp_public/ enter_search. In several cases, the choice of organizational form indicated by Martindale-Hubble or NALP varied from information provided by the law firm's website and the New York Department of State. In these cases, we used the information provided by the New York Department of State.

58. For example, Martindale-Hubble lists Milberg, Weiss as having its main office in New York. However, the firm's website indicates that its main office is in San Diego. Accordingly, we adopted the website's designation of the firm's main office and excluded Milberg, Weiss from our sample. This cross-check was conducted in March 2004

59. The American Lawyer publishes the AmLaw 100 in the July edition of the magazine and the AmLaw 200 in the August edition of the magazine. See, e.g., The AmLaw 100, 2004, THE Am. LAw., July 2004, at 91; The Amlaw 200, 2004, The Am. LAw., Aug. 2004, at 83. Data on the AmLaw 100 were available for the years 1993-2003. The American Lawyer only published data on the AmLaw 200 for the years 1999-2003. 
between the lawyer and client in these firms than in others and they, therefore, have less need to signal quality by being a GP.

In addition, both the average number of in-house counsel (INHOUSE-AVG) and the total number of in-house counsel (IN-HOUSETOTAL) were used as a proxy for the level of client-lawyer information asymmetry. ${ }^{60}$ Consistent with prior research on the role of in-house counsel in reducing this asymmetry, our theory was that firms with a higher number of both average and total in-house counsel should have lower levels of information asymmetry and, therefore, less need to signal quality by remaining a GP.

The Directory of In-House Departments provided client information and information on each client's number of in-house counsel. ${ }^{61}$ Of the 118 firms that are LLPs or GPs, only forty firms have clients in the Fortune 250.

\section{5. $\quad$ Starting Associate Salaries (SALARY), Multi-Tiered Partnership Structure (TIER), and Collegiality (COLLEGIAL)}

NALP provided starting associate salaries, whether the firm used a multi-tiered partnership structure, and whether the firm self-identified as collegial. TIER indicates whether or not the firm employs a multi-tier partnership structure. TIER was collected from the NALP On-Line Directory of Legal Employers for the fifty-four firms in our sample that are included in the on-line directory. ${ }^{62}$

COLLEGIAL indicates whether or not the firm self-identifies as collegial. Firms can identify themselves as collegial through the narrative description that they provide to NALP for publication. A research assistant labeled the sixty firms in our sample that were listed in the 20022003 NALP directory (print version) as congenial/collegial or not congenial/collegial. To determine which category the firm best fit in, we examined the narrative information included in their NALP entry. Descriptions of the firms that stressed "teamwork," a "congenial" or "collegial" environment, and "friendly," or "close-working relationships" were

60. See Ryon Lancaster \& Brian Uzzi, From Colleague to Employee: Determinants of Changing Career Governance Structures in Elite U.S. Law Firms (working draft, on file with authors) (using this same variable to test the level of information asymmetry in the market for legal services).

61. The searchable directory is available at $\mathrm{http}: / / \mathrm{solis} .365$ media.com $/ \mathrm{alm} / \mathrm{search}$. asp?cat= 987223. The variables were constructed by searching for each firm's name in the directory. If the firm has Fortune 250 clients, then the directory provides the client names, along with the number of inhouse-counsel employed by each client.

62. This information was collected from the NALP web directory in June 2004. The NALP web directory is located at http://www.nalpdirectory.com. There is an entry on each form entitled "Partnership Data." One item under this heading is "Two or more tiers?," to which firms respond "yes" or "no." 
coded as collegial. Firms that did not mention any of these characteristics in their narrative description were coded as uncollegial. ${ }^{63}$

One might expect that every firm would advertise its congeniality as a marketing tool, rendering firms' narrative statements a poor proxy for collegiality. In fact, however, there is great variation in the narrative descriptions and only forty-seven percent of the New York firms in our sample were coded as collegial. ${ }^{64}$ In addition, COLLEGIAL was negatively associated with TIER as one would expect if these two variables are acting as a proxy for the firm's level of collegiality.

SALARY measures each firm's starting associate salary as reported in the NALP On-Line Directory of Legal Employers. ${ }^{65}$ SALARY was calculated for the fifty-four firms in our sample for which such information was provided in the On-Line Directory.

\section{Raw Data}

The raw data for New York law firms are attached as Appendices A-D to this article. Appendix A lists LAWYERS, FORM, OFFICES, DATE, and GROWTH for all firms in the sample. Appendix B reports TIER, SALARY, and COLLEGIAL for the subset of firms for which such information was available. ${ }^{66}$ Appendix C lists IN-HOUSE-AVG, IN-HOUSE-TOTAL, and FORTUNE for the subset of firms for which such information is available. Appendix D contains the PROFITS data.

\section{B. Empirical Results}

\section{General Results}

Tables 1,2, and 3 report summary statistics for the data collected on New York law firms. As is evident, the large majority of firms (67\%) are LLPs, whereas only $13 \%$ are GPs. ${ }^{67}$ The average number of offices is higher for LLPs than for GPs, as is the average number of lawyers. As demonstrated in the logit model in Part II.B.3.b, however, neither of these variables is a statistically significant predictor of the choice of organizational form.

63. See Gorman, supra note 26, at 650 (using the NALP narrative descriptions to construct a dummy variable for whether or not the firm was collegial).

64. Similarly, in a national study of collegiality at law firms using this same coding method, only about twenty percent of the firms were coded as collegial and collegiality was negatively associated with a multi-tiered partnership structure. See id. at 650-51.

65. This information was collected from the NALP web directory in June 2004. All salaries are those reported for 2003, except in the case of two firms that provided only 2004 salary information. The firms are: Thacher, Proffit, \& Wood and Friedman, Kaplan, Siler, \& Adelman.

66. Note that information on each variable is not available for all firms in Appendix B. A blank space indicates that information on this variable was unavailable for the firm in question.

67. The remaining firms are PCs and LLCs. See infra note 69 (breaking down these numbers). 
TABLE 1

OVERALL STATISTICS

\begin{tabular}{|c|c|c|}
\hline Firm Type & Total Number & Percentage of Sample \\
\hline GP & 19 & $13 \%$ \\
\hline LLP & 99 & $67 \%$ \\
\hline PC & 27 & $18 \%$ \\
\hline LLC & 2 & $1 \%$ \\
\hline
\end{tabular}

TABLE 2

GP SUMMARY STATISTICS

\begin{tabular}{|c|c|}
\hline Avg. Number of Offices & 4.263158 \\
\hline Std. Dev. Number of Offices & 3.841905 \\
\hline Avg. Number of Lawyers & 181.1579 \\
\hline Std. Dev. Number of Lawyers & 214.7811 \\
\hline
\end{tabular}

TABLE 3

LLP SUMMARY STATISTICS

\begin{tabular}{|c|c|}
\hline Avg. Number of Offices & 5.232323 \\
\hline Std. Dev. Number of Offices & 6.54471 \\
\hline Avg. Number of Lawyers & 240.798 \\
\hline Std. Dev. Number of Lawyers & 446.6612 \\
\hline
\end{tabular}

\section{2. $\quad$ Filing Patterns}

In order to examine law firm filing patterns, we divided the firms in our sample into large firms, small firms, and elite firms. ${ }^{68}$ Information regarding the LLP filing dates of large firms, small firms, and elite firms is graphically depicted in Chart 1.

As the bar chart shows, LLP filings peaked in 1994-1995, the twoyear period after New York's LLP statute became effective, and were distributed roughly equally between large and small firms. Few elite firms filed during this time period.

LLP filings then tapered off, but began rising again between 2001 and 2003. Unlike the 1994-1995 filing period, large firms dominate the LLP filings during the 2001-2003 period. In particular, a large number of elite law firms filed during this period, roughly coinciding with two events: the Arthur Andersen trial and bankruptcy, and the large numbers of securities fraud suits accompanying the stock market downtown associated with the burst of the "dotcom" bubble.

68. "Large firms" are firms with more than fifty lawyers in 2004. "Small firms" are firms with between twenty-five and fifty lawyers in 2004 . "Elite firms" are defined as firms with more than $\$ 1$ million in profits per partner for 2002. 
CHART 1

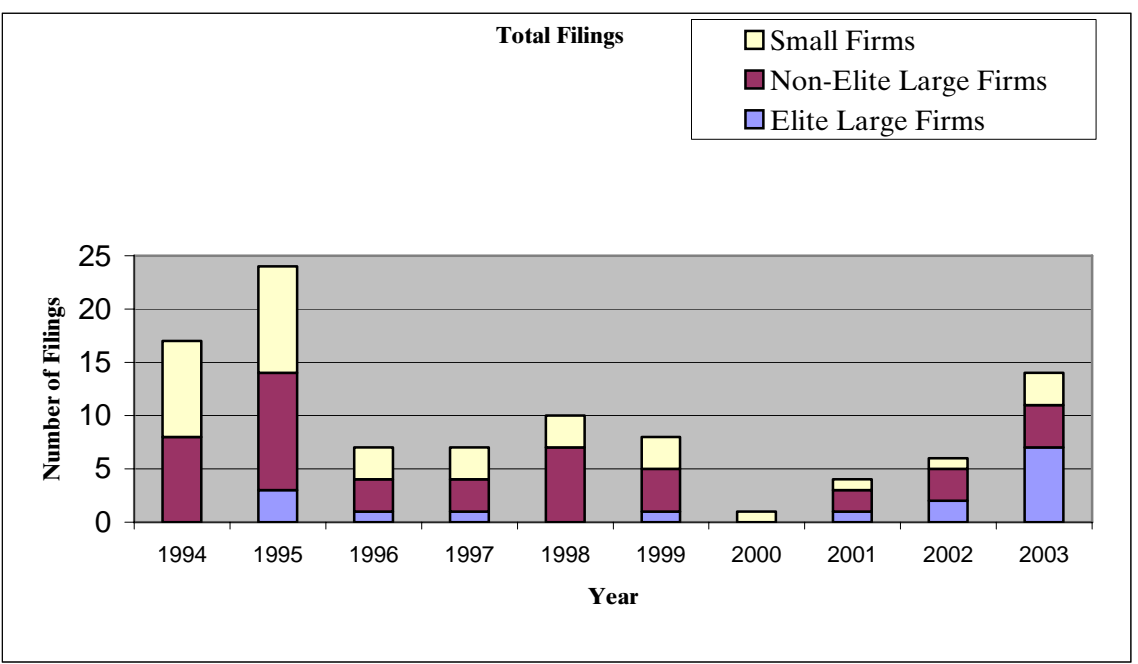

Given the large numbers of securities offerings in which these firms are involved, and the corresponding liability fears that may result, we theorized that many large and elite law firms may have consciously chosen this time frame in which to seek liability protection. This conjecture is supported by our interview data. Our follow-up interviews reveal that both rising liability fears and the Arthur Andersen bankruptcy were salient factors associated with many firms' decisions to opt for LLP status. ${ }^{69}$

LLP filing dates plotted against 2003 PROFITS are graphically depicted in Chart $2 .^{70}$ The chart shows a rough bunching of LLP filings that corresponds with PROFITS. As discussed in more detail in Part IV, we believe that this is attributable to a concern by firms with the negative signal that may accompany an LLP filing. However, as more firms that the decision-making firm considers to be a competitor convert to LLP status, the negative signal is muted. For this reason, firms tend to file with their cohort. The interview data supports this notion that firms account for the actions of competitor firms when making a decision regarding organizational form. ${ }^{71}$

Two apparent outliers in Chart 2 are noteworthy: the LLP filing of Milbank, Tweed on February 1, 1999, and the LLP filing of Skadden, Arps on May 25, 2001. Both of these firms filed early relative to firms with comparable profits-per-partner, and both filings were noted with interest by their cohort firms. The Milbank filing closely followed the con-

69. See infra notes 120-23 and accompanying text (discussing Arthur Andersen and rising liability fears as salient factors in law firms' choice of organizational form).

70. Because per partner profit data is reported in American Lawyer for only the 200 most profitable firms in the United States, only thirty-six of our original sample of 147 firms are included on this chart.

71. See infra notes 118-19 and accompanying text (discussing this phenomenon). 
viction and sentencing of Milbank partner John Gellene in the summer of 1998 to fifteen months in federal prison for filing false declarations in a bankruptcy proceeding. ${ }^{72}$ Although several partners at New York firms surmised during interviews that the Gellene incident may have made liability matters more salient at Milbank and prompted the firm's early filing, our interviews with Milbank suggest that this was not the case. ${ }^{73}$ The Skadden filing in 2001 gained the attention of many elite New York firms and, according to our interviews, caused many firms to begin reevaluating the decision of whether to become an LLP. ${ }^{74}$ Although many interviewees indicated that the firm eventually decided to wait until firms within their cohort other than Skadden were prepared to file before their own firm was willing to file, the event was clearly a salient trigger in many firms' decision-making processes. ${ }^{75}$

\section{CHART 2}

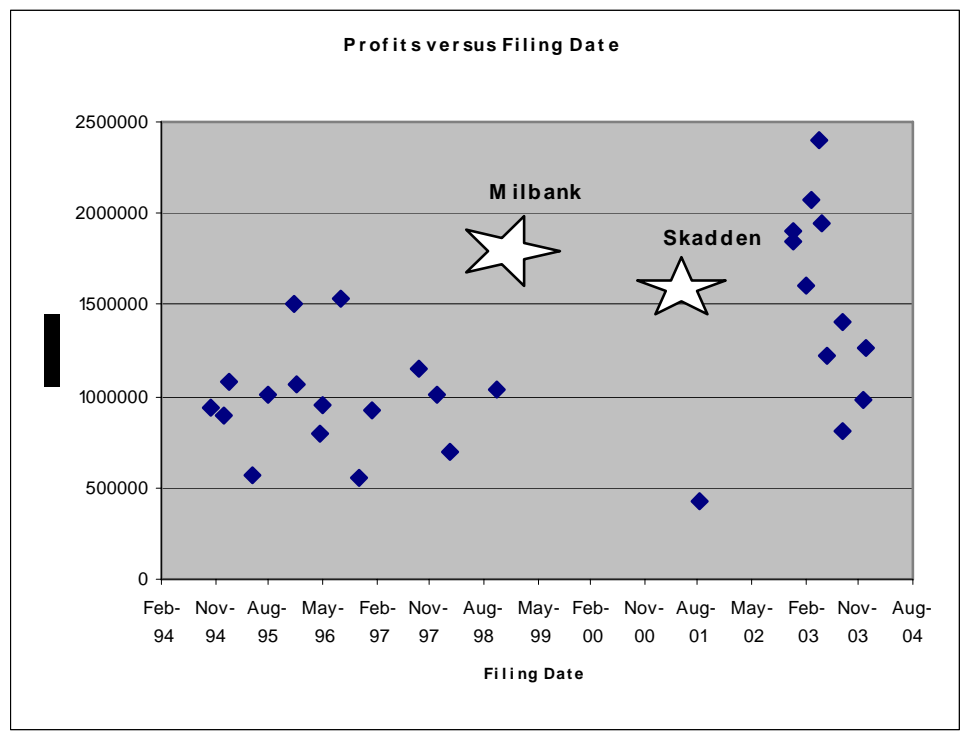

Another area in which law firms compete is starting associate salaries. ${ }^{76}$ Accordingly, we predicted that law firms might also look to the

72. See Milton Regan, Eat What You Kill: The Fall of a Wall Street Lawyer (2004); Alison Frankel, Trading One Striped Suit (with Cuffs) for Another, AM. LAW., Oct. 1998, at 10 (discussing the Gellene incident).

73. Confidential interview with partner of Milbank, Tweed, Hadley \& McCloy LLP in New York, N.Y. (June 16, 2004) (attributed with permission of interview subject) (interview notes on file with the authors).

74. Confidential interviews with law firm partners (interview notes on file with the authors).

75. Id.

76. See Bruce M. Price, A Butterfly Flaps Its Wings in Menlo Park: An Organizational Analysis of Increases in Associate Salaries (unpublished draft, on file with authors) (demonstrating that law firms compete on associate salaries, even when doing so appears to make little sense as an economic matter). 
behavior of firms with whom they compete on starting salaries in making decisions about organizational form, resulting in clusters when associate starting salaries are plotted against filing dates. LLP filing dates plotted against first year associate starting salaries are graphically depicted in Chart 3. Unfortunately, at this point in time, there is so little variation in starting associate salaries among the New York firms for which data is available that the chart reveals no useful information.

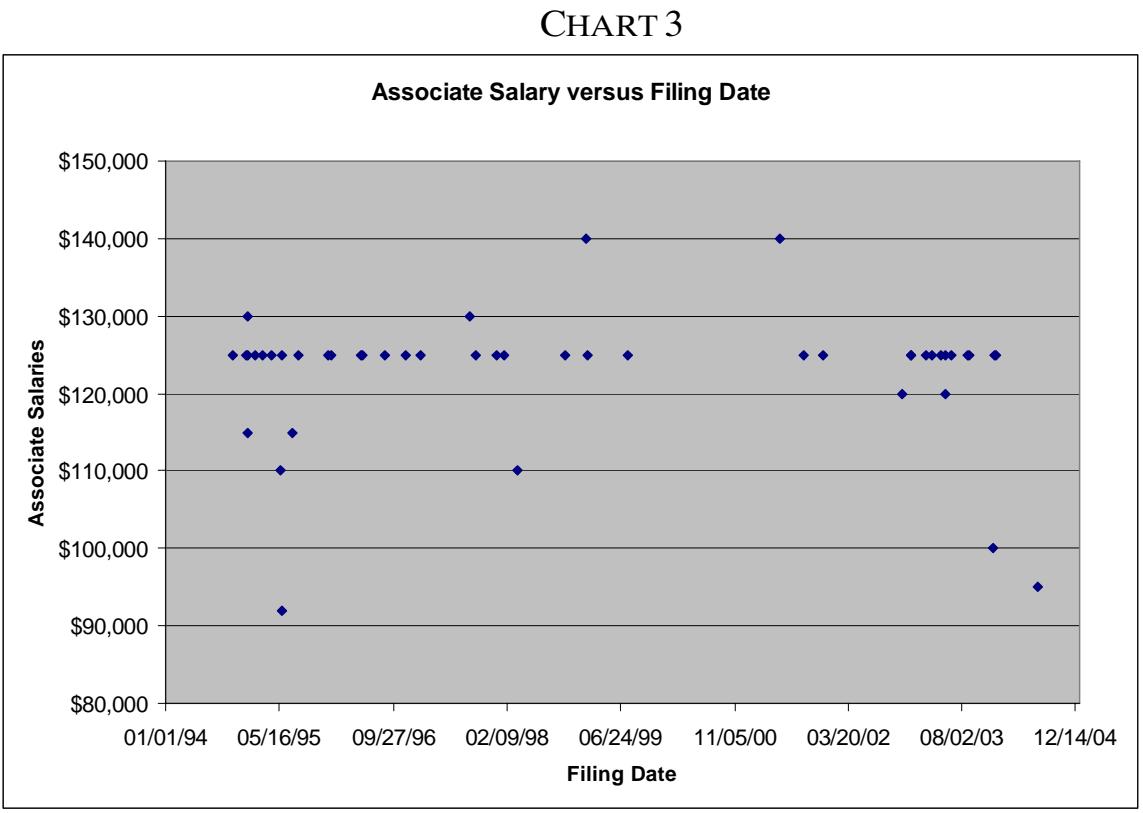

\section{Testing the Partnership Theories}

\section{a. Profit-Sharing and Illiquidity-Based Theories}

In Part II of this article, we discussed four theories of partnership that are based on the purported benefits of profit sharing through partnership: insurance, monitoring, quality signaling, and preventing grabbing and leaving. In addition, we discussed one partnership theorymentoring - that relies on the illiquidity benefits of the partnership form. As noted, there are reasons to approach each of these theories with suspicion because, assuming that profit-sharing and illiquidity are valuable attributes in at least some business and professional organizations, the partnership form is unnecessary to provide these benefits. Both profitsharing and illiquidity can be, and frequently are, replicated through a variety of organizational forms, including the LLC, PC, and corporation.

Nonetheless, each of these theories generates a testable hypothesis. If any of these partnership theories fully explains the benefits of the 
partnership form, then all or nearly all of the firms in our sample should be LLPs, because the LLP provides the same illiquidity and profitsharing features of the GP, without the accompanying costs of unlimited liability. Contrary to the predictions of the illiquidity and profit-sharing based hypotheses, a sizeable number of firms in our sample remain GPs.

Standing alone, however, our empirical data allow us only to reject the illiquidity and profit-sharing based theories of partnership as the sole motivation for the choice of organizational form among New York law firms. However, our theoretical objections to these theories, detailed throughout this article, cause us to doubt that they are even contributing factors in the choice of organizational form, much less decisive ones.

\section{b. Limited Liability, Monitoring, and Collegiality}

i. Results

As discussed in Part II of this article, several partnership theories rely on the purported benefits of unlimited liability. Under the monitoring theory, unlimited liability induces partners to more carefully scrutinize each other. This monitoring becomes more difficult with increased size, rate of growth, and geographic dispersion of the firm. In contrast, the collegiality theory of partnership asserts that the willingness to face personal liability for a partner's acts generates trust and collegiality within the firm. Larger groups, quickly growing groups, more geographically dispersed groups, and firms with multi-tiered partnership structures are considered less collegial than small, closely-knit groups, in which all members are treated equally. In addition, some law firms self-identify as collegial in their NALP narrative statement whereas others do not. Accordingly, the monitoring and collegiality partnership theories each yield a testable hypothesis: if either of these theories is a significant rationale for the choice of organizational form among New York law firms, then regression results should reveal a statistically significant effect of LAWYERS, OFFICES, and GROWTH, and in the case of the collegiality theory, TIER and COLLEGIAL, on the choice of organizational form.

In order to test this hypothesis, we estimated a logit model with the dependent discrete variable being whether the firm was an LLP or GP. The independent variables are LAWYERS, OFFICES, GROWTH, and whether the firm is domestic or foreign (FOREIGN). The model had 117 observations. Although there are a total of 118 GPs and LLPs in the data, GROWTH was unavailable for one firm.

As Table 4 reports, the coefficients on all variables are insignificant. $^{77}$ Note, however, that OFFICES and LAWYERS are correlated,

77. We also ran a probit model, which assumes a slightly different structure. See WiLliam H. GREENE, ECONOMETRIC ANALYSIS 814-15 (4th ed. 2000). As in the logit model, the coefficients on 
raising the possibility of a multicollinearity problem. Without using additional independent variables or collecting more data, we cannot correct for this problem. ${ }^{78}$ With this qualification in mind, the initial indications from the data are that neither the monitoring nor the collegiality hypotheses find much support.

\section{TABLE 4}

Logit estimates

Number of obs $=117$

Log pseudo-likelihood $=-49.7556$

Pseudo R2 $=0.0414$

\begin{tabular}{|l|l|l|l|l|l|}
\hline & Coef. & $\begin{array}{l}\text { Robust } \\
\text { Std. Er- } \\
\text { ror }\end{array}$ & $\mathrm{z}$ & $\mathrm{P}>|\mathrm{z}|$ & $\begin{array}{l}{[95 \% \text { Conf. Inter- }} \\
\text { val }]\end{array}$ \\
\hline LAWYERS & .0003985 & .0007504 & 0.53 & 0.595 & $\begin{array}{l}-.0010723 \\
.0018693\end{array}$ \\
\hline OFFICES & .0283613 & .0524437 & 0.54 & 0.589 & $\begin{array}{l}-.0744265 \\
.1311491\end{array}$ \\
\hline GROWTH & .0011623 & .01928 & 0.06 & 0.952 & $\begin{array}{l}-.0366258 \\
.0389503\end{array}$ \\
\hline FOREIGN & -1.748595 & .9146515 & -1.91 & 0.056 & $\begin{array}{l}-3.541279 \\
.0440886\end{array}$ \\
\hline CONST & 1.566562 & .3697773 & 4.24 & 0.000 & $\begin{array}{l}.8418118 \\
2.291312\end{array}$ \\
\hline
\end{tabular}

The logit results are based on a relatively small number of firms, an unavoidable problem for this population. Although we collected data on all New York City firms listed in Martindale-Hubble and NALP with more than twenty-five lawyers, rather than drawing a sample of such firms, this is, nonetheless, still a limited number of observations. ${ }^{79}$

As an additional check on the robustness of the significance results, we bootstrapped the sample, a process that involves resampling from the data. The computational technique randomly draws with replacement a

all variables were insignificant. In a provocative new working paper, Eric Talley and John Romley conduct a nationwide inquiry into law firm choice of form. Romley \& Talley, supra note 47 . They find that a firm's size-measured in terms of the number of lawyers in 1993-is a statistically significant predictor of the law firm's choice of organizational form as of 1999. Id. at 31-32 \& tbl.11.

78. Dropping one of the correlated variables is a common but incorrect fix for multicollinearity. See Peter Kennedy, A Guide To Econometrics 182 (4th ed. 1992). Because this incorrect correction is frequently used, however, we also ran two additional models. In the first model, we dropped LAWYERS as an independent variable, but kept OFFICES. In the second model, we dropped OFFICES, and kept LAWYERS. Neither OFFICES nor LAWYERS was significant when run without the presence of the other in the regression. In addition, we tested the joint significance of OFFICES and LAWYERS. We could not reject the hypothesis that the coefficients on both variables equal zero.

79. Some firms, especially smaller firms, may choose not to list in Martindale-Hubble or NALP, because such listing involves a fee. So, while we are confident that our dataset includes most New York law firms, the data set may not include all New York firms. This potential selection bias among smaller firms is one reason that we did not include in our sample firms with fewer than twenty-five lawyers. 
new sample from the data at hand. ${ }^{80}$ The logit model is then run on each of the bootstrapped samples. ${ }^{81}$

Because bootstrapping resamples from the same data, it is only appropriate when certain assumptions are met. Specifically,

We must be prepared to assume that the empirical distribution function represented by the sample is a good estimator of the population distribution function that generated the sample in the first place. That is, we must believe that a representative sample of all possible distinct values of the population is found in our data. ${ }^{82}$

We believe that our dataset meets this assumption because of the method of data collection. As previously noted, our dataset represents the entire population of New York City firms with more than twenty-five lawyers, as reported by Martindale-Hubble and NALP. ${ }^{83}$

Table 5 summarizes the bootstrapping results. The coefficients on GROWTH, LAWYER, and OFFICE are insignificant for all three methods for constructing bootstrap confidence intervals. ${ }^{84}$ The coefficient on FOREIGN was insignificant for two of the methods for constructing intervals and significant for one of the methods. ${ }^{85}$

TABLE 5

bootstrap statistics

Number of obs $=117$

Replications $=1000$

\begin{tabular}{|c|c|c|c|c|c|}
\hline Variable & Reps & Observed & Bias & Std. Err. & [95\% Conf. Interval] \\
\hline B_LAWYERS & 1000 & .0003985 & -.00004 & .0015948 & $\begin{array}{lll}-.002731 & .0035279 & (\mathrm{~N}) \\
-.0031016 & .0037558 & (\mathrm{P}) \\
-.0030128 & .004021 & (\mathrm{BC})\end{array}$ \\
\hline B_OFFICES & 1000 & .0283613 & .0253877 & .0859417 & $\begin{array}{lll}.1402856 & .1970082 & (\mathrm{~N}) \\
-.0809225 & .2596718 & (\mathrm{P}) \\
-.1091741 & .1871728 & (\mathrm{BC})\end{array}$ \\
\hline B_GROWTH & 1000 & .0011623 & .0054339 & .0309361 & $\begin{array}{lll}-.0595449 & .0618694 & (\mathrm{~N}) \\
-.0491735 & .0783014 & (\mathrm{P}) \\
-.0584999 & .0620802 & (\mathrm{BC})\end{array}$ \\
\hline B_FOREIGN & 947 & -1.74859 & -.22967 & 1.334121 & $\begin{array}{lll}-4.366775 & .8695839 & (\mathrm{~N}) \\
-4.961497 & -.0081233 & (\mathrm{P}) \\
-4.125079 & .086775 & (\mathrm{BC})\end{array}$ \\
\hline
\end{tabular}

80. See Christopher Z. MOONEy \& ROBERT D. DUVAl, BoOtstrapping: A NONPARAMETRIC APPROACH TO STATISTICAL INFERENCE 9-15 (1993) (describing how bootstrapping works generally).

81. Bootstrapping is useful in developing confidence intervals. Id. at 60 . However, the parameter estimates from bootstrapping are unreliable, a problem that does not concern us here, as we are concerned only with the significance of the results. Id.

82. Id. at 60-61 (emphasis added).

83. See supra note 79 (discussing the dataset).

84. See MoONEY \& DUVAL, supra note 80, at 33-42 (describing the different ways to construct bootstrap confidence intervals).

85. The replication for FOREIGN only occurred 947 times. This means that in fifty-three of the resamples, the sampling did not draw any foreign firms, making it impossible to run the logit on those resamples. 
TABLE 5-Continued

\begin{tabular}{|l|l|l|l|l|lll|}
\hline B_CONST & 1000 & 1.566562 & -.048501 & .4290887 & .7245433 & $2.408581(\mathrm{~N})$ \\
& & & & & .7236955 & $2.400121(\mathrm{P})$ \\
& & & & & .8607135 & $2.549127(\mathrm{BC})$ \\
\hline
\end{tabular}

Finally, as an additional test of the collegiality hypothesis, we estimated a logit model for the subset of fifty-three firms for which data on both COLLEGIAL and TIER was available. Table 6 reports the logit results from this subsample. As with the other models, the coefficients on all variables were statistically insignificant.

TABLE 6

Logit estimates

Number of obs $=53$

Log pseudo-likelihood $=-19.406266 \quad$ Pseudo R2 $=0.0619$

\begin{tabular}{|l|c|l|l|l|ll|}
\hline & Coef. & $\begin{array}{l}\text { Robust } \\
\text { Std. } \\
\text { Error }\end{array}$ & $\mathrm{z}$ & $\mathrm{P}>|\mathrm{z}|$ & {$[95 \%$ Conf. Interval $]$} \\
\hline LAWYERS & .0002044 & .0007751 & .26 & 0.792 & -.0013147 & .0017236 \\
\hline OFFICES & .0511103 & .0785404 & 0.65 & 0.515 & -.1028261 & .2050466 \\
\hline GROWTH & -.0692595 & .0474476 & -1.46 & 0.144 & -.1622552 & .0237361 \\
\hline FOREIGN & -1.390741 & 1.368034 & -1.02 & 0.309 & -4.07204 & 1.290557 \\
\hline COLLEGIAL & .2180422 & .8244907 & 0.26 & 0.791 & -1.39793 & 1.834014 \\
\hline TIER & -.002586 & 1.052599 & -0.00 & 0.998 & -2.065643 & 2.060471 \\
\hline CONST & 1.979628 & .7010438 & 2.82 & 0.005 & .6056078 & 3.353649 \\
\hline
\end{tabular}

However, one cannot make a strong inference from the results in Table 6. The sample size is too small, making heavy reliance on the results unjustifiable. ${ }^{86}$

\section{ii. Section Summary}

To summarize this subsection, given the results on the entire sample, the bootstrapping results, and the preliminary results on firms reporting TIER and COLLEGIAL information, the indications from the data are that neither the monitoring nor the collegiality hypotheses find much support in the data. Although the coefficient on FOREIGN was insignificant, except in one method for constructing intervals in the bootstrapping results, three out of eight foreign firms were GPs, a much higher proportion of GPs than in the total sample. Although we hesitate to read too much into this result because of the small number of foreign firms in the sample, our interview results provide some insight into why the filing patterns among foreign firms, especially U.K. firms, may differ from the filing patterns of domestic firms.

86. We also bootstrapped this smaller sample. The coefficients on all variables were insignificant when bootstrapped. However, we are not confident about these results because the smaller sample may not be representative of the population under study. See id. at 60-61 (discussing the limitations of the bootstrap technique). 
For most law firms based outside of the United States, the New York office represents a relatively small percentage of the total partnership. Accordingly, were the firm to seek liability protection, most would prefer another avenue, such as filing as a limited liability entity in their own country, to accomplish it. ${ }^{87}$ Although many jurisdictions have recently modernized their limited liability laws available to professional associations, making them more attractive, there are still impediments to limited liability in many jurisdictions ${ }^{88}$ Accordingly, although many large law firms based outside of the United States are currently considering the issue of becoming a limited liability entity, and many of our interview subjects predicted that all of the major international firms based outside of the United States would soon follow the lead of the domestic firms, these practical impediments have slowed the process among many foreign firms. ${ }^{89}$

\section{c. The Relationship Between Profits and Choice of Form}

Recall that the unlimited liability version of the monitoring theory suggests that, because LLPs provide an inferior legal product, they must either (1) charge less, or (2) suffer reduced revenues. As discussed below in Part IV, our interview data allow us to reject the first possibility. This subsection considers the second possibility, investigating the link between choice of organizational form and profits-per-partner.

As noted previously, we collected profit per partner data for the years 1993-2003 on the thirty-six firms in our sample that were listed among the 200 most profitable in the country. The goal of this section is to determine whether a switch in form from a GP to an LLP had any effect on firm profitability. This is a panel data set, in which we observe the same firms over a ten-year span. During this span, thirty-one firms changed from a GP to an LLP; five firms remained GPs.

To determine whether a change of form had any effect on profits, we ran a fixed effects model that accounts for unobservable firm-specific traits and secular trends, both of which - if unaccounted for-might af-

87. Confidential interview with senior partner at foreign law firm in London, England (July 12, 2004) (interview notes on file with the authors).

88. For example, U.K. law firms that choose to limit their liability must make their financial statements publicly available, a requirement that has caused many U.K. firms to forgo the benefit of the statute. Confidential interview with senior partner at foreign law firm in London, England (July 12,2004 ) (interview notes on file with the authors). In addition, law firms with a substantial German practice must contend with German tax laws that deem partnership goodwill recognized if the firm changes its organizational form. Although it is apparently possible to get a firm-specific ruling waiving the statute, the ease and speed with which this occurs varies by jurisdiction. Id.

89. One of the U.K.'s leading law firms, Allen \& Overy, recently became a U.K. LLP effective on May 1, 2004. Many predict that other major UK firms will soon follow suit. See Bob Sherwood, $A$ Question of Protection: Limited Liability, Fin. TIMES, Apr. 26, 2004, at 11. 
fect profitability. ${ }^{90}$ The independent variables include dummy variables for the filing date and the lags of the filing date.

The variable, FILING, equals one if the firm filed for LLP status in that year and zero otherwise. The variable, FILLAG1, equals one if the firm filed as an LLP in the previous year and zero otherwise. The remaining variables, FILAG2, FILAG3, FILAG4, FILAG5, FILAG6, FILAG7, FILAG8, are defined in a similar fashion. These lags of the filing date allowed us to examine whether the switch in form had a persistent and/or delayed impact on profits.

Tables 7 and 8 summarize the results. The dependent variable in Table 7 is the level of profits. The dependent variable in Table 8 is the $\log$ of profits. The log function compresses the profit data, reducing the impact of outliers on the results. ${ }^{91}$ In both tables, we suppress the estimates on the time dummy variables, which account for the secular trends. As Table 7 reports, many of the filing variables are statistically significant and negative. One must be careful, however, in interpreting the point estimates. Take, for instance, the estimate on FILAG6, which is 184,515.5. Roughly speaking, this means that, all else being equal, a firm that files for LLP status in 1997 will have \$184,515.50 less profits in 2003.

In Table 8 , none of the filing variables is statistically significant and the point estimates flip signs, starting negative and turning positive as the length of the lag increases. ${ }^{92}$ The results in Table 8 caution us against reading too much into the results from Table $7 . .^{93}$ Given the results in Table 7, however, we cannot completely dismiss the possibility that a switch in form from a GP to an LLP reduces profitability, at least in the first few years.

\section{TABLE 7}

Regression with robust standard errors Number of obs $=344$

$$
\mathrm{R} \text {-squared }=0.9147
$$

Adj R-squared $=0.8987$

(standard errors adjusted for clustering on firm)

firm absorbed (36 categories)

\begin{tabular}{|l|l|l|l|l|lc|}
\hline Robust profits & Coef. & Std. Err. & $\mathrm{t}$ & $\mathrm{P}>\mathrm{t}$ & {$[95 \%$ Conf. Interval] } \\
\hline FILING & -21258.85 & 44453.78 & -0.48 & 0.633 & -108753.1 & 66235.37 \\
\hline FILAG1 & -87008.55 & 66094.87 & -1.32 & 0.189 & -217096.9 & 43079.8 \\
\hline \multicolumn{4}{|c}{} & \multicolumn{4}{c|}{ (Continued on next page) } \\
\hline
\end{tabular}

90. For a nontechnical discussion of the fixed effects model, see JEFFREY M. WOOLDRIDGE, INTRODUCTORY ECONOMETRICS: A MODERN APPROACH 461-69 (2d ed. 2003).

91. See infra note 96 (discussing the effect of the log function).

92. When the dependant variable is the log of profits, the coefficient estimates represent the percentage change in profits. So, for example, in Table 8, the estimate on FILAG2 equals -.09. This means, all else equal, a switch in form from a GP to an LLP in 1999 leads to nine percent less profits in 2001.

93. The results from Table 7 do not seem to be the result of outliers. We reran the model with profit levels as the dependant variable, but dropped the firms that had the three highest profits per partner and the three lowest profits per partner in 2003. The same results occur: The filing date coefficients are all negative and many of the lag variables are statistically significant. 
TABLE 7-Continued

\begin{tabular}{|l|l|l|l|l|ll|}
\hline Robust profits & Coef. & Std. Err. & $\mathrm{t}$ & $\mathrm{P}>\mathrm{t}$ & \multicolumn{3}{|c|}{$95 \%$ Conf. Interval] } \\
\hline 1FILAG2 & -174411.4 & 84025.32 & -2.08 & 0.039 & -339790.6 & -9032.259 \\
\hline FILAG3 & -187735.9 & 101827.9 & -1.84 & 0.066 & -388154.2 & 12682.44 \\
\hline FILAG4 & -159628.4 & 94619.01 & -1.69 & 0.093 & -345858.1 & 26601.35 \\
\hline FILAG5 & -188473.5 & 81811.78 & -2.30 & 0.022 & -349495.9 & -27450.98 \\
\hline FILAG6 & -184515.5 & 80088.32 & -2.30 & 0.022 & -342145.8 & -26885.14 \\
\hline FILAG7 & -150712.8 & 88654.57 & -1.70 & 0.090 & -325203.3 & 23777.66 \\
\hline FILAG8 & -162935.3 & 85871.46 & -1.90 & 0.059 & -331948 & 6077.454 \\
\hline CONS & 602822.1 & 40466.9 & 14.90 & 0.000 & 523174.9 & 682469.3 \\
\hline
\end{tabular}

TABLE 8

Regression with robust standard errors Number of obs $=344$

$$
\text { R-squared }=0.9469
$$

Adj R-squared $=0.9370$

(standard errors adjusted for clustering on firm) firm | absorbed (36 categories)

\begin{tabular}{|l|l|l|l|l|ll|}
\hline In_profits & $\begin{array}{l}\text { Robust } \\
\text { Coef. }\end{array}$ & Std. Err. & $\mathrm{t}$ & $\mathrm{P}>|\mathrm{t}|$ & {$[95 \%$ Conf. Interval $]$} \\
\hline FILING & -.0093797 & .0432447 & -0.22 & 0.828 & -.0944943 & .0757348 \\
\hline FILAG1 & -.0534657 & .0582221 & -0.92 & 0.359 & -.1680588 & .0611273 \\
\hline FILAG2 & -.0919802 & .0692698 & -1.33 & 0.185 & -.2283174 & .044357 \\
\hline FILAG3 & -.038596 & .0662408 & -0.58 & 0.561 & -.1689716 & .0917795 \\
\hline FILAG4 & .04744 & .0734623 & 0.65 & 0.519 & -.0971489 & .192029 \\
\hline FILAG5 & .0593914 & .0647471 & 0.92 & 0.360 & -.0680443 & .1868272 \\
\hline FILAG6 & .0809359 & .0774825 & 1.04 & 0.297 & -.0715656 & .2334375 \\
\hline FILAG7 & .1255982 & .0885678 & 1.42 & 0.157 & -.0487215 & .299918 \\
\hline FILAG8 & .109464 & .0799982 & 1.37 & 0.172 & -.047989 & .2669169 \\
\hline CONST & 13.23817 & .0368891 & 358.86 & 0.000 & 13.16556 & 13.31077 \\
\hline
\end{tabular}

\section{d. Unlimited Liability and Signaling}

As discussed in Part II.D.1 of this article, unlimited liability is thought to send a positive signal to customers by indicating that, because each partner's personal assets are at stake in the event of her own or another partner's blunder, each partner will take more care in the provision of legal services and will more carefully monitor other firm members. Because the quality signaling theory depends on information asymmetry between the firm and its clients, the signaling theory suggests that firms whose clients possess less information regarding the quality of legal services they receive should have a greater need to engage in this type of quality signaling than firms whose clients are well informed regarding the quality of legal services.

To test this hypothesis, we predicted a positive, significant relationship between each of IN-HOUSE-AVG, IN-HOUSE-TOTAL, and FORTUNE on the probability that a firm is an LLP. Tables 9 and 10 report the results on signaling. In Table 9, FORM again serves as the discrete dependent variable. The independent variables include GROWTH, OFFICES, and FOREIGN, plus FORTUNE. The coeffi- 
cients on LAWYERS, OFFICES, and FORTUNE are all insignificant. ${ }^{94}$ However, the coefficient on FOREIGN was significant in this model. ${ }^{95}$

\section{TABLE 9}

Logit estimates

$$
\text { Number of obs }=117
$$

Log pseudo-likelihood $=-47.700453$

Pseudo R2 $=0.0810$

\begin{tabular}{|l|l|l|l|l|ll|}
\hline & Coef. & $\begin{array}{l}\text { Robust } \\
\text { Std. Error }\end{array}$ & $\mathrm{z}$ & $\mathrm{P}>|\mathrm{z}|$ & {$[95 \%$ Conf. Interval $]$} \\
\hline LAWYERS & .003625 & .0029158 & 1.24 & 0.214 & -.0020897 & .0093398 \\
\hline OFFICES & -.0196299 & .063816 & -0.31 & 0.758 & -.144707 & .1054471 \\
\hline GROWTH & -.0016844 & .0195909 & -0.09 & 0.931 & -.0400818 & .0367131 \\
\hline FOREIGN & -2.266825 & 1.073779 & -2.11 & 0.035 & -4.371393 & -.1622578 \\
\hline FORTUNE & -.2088203 & .1224337 & -1.71 & 0.088 & -.4487859 & .0311453 \\
\hline CONST & 1.638935 & .4037346 & 4.06 & 0.000 & .8476294 & 2.43024 \\
\hline
\end{tabular}

Table 10 summarizes the results from the last logit model. The sample for this model contains only thirty-nine observations and, hence, the results are suggestive at best. The sample includes only those firms who represent clients in the Fortune 250. In this model, we add as an independent variable the log of the average number of in house counsel (IN-HOUSE-AVG) and the total number of in-house counsel (INHOUSE-TOTAL). ${ }^{96}$ The coefficients on all variables are statistically insignificant. ${ }^{97}$

In contrast to the statistical tests of the other theories, the data here is weaker. As a result, our conclusion is more tentative. The proxies for information asymmetry are just that-proxies. ${ }^{98}$ That said, when com-

94. We also ran a model with whether the firm had any clients in the Fortune 250 as a dummy variable. In this model as well, all the coefficients were statistically insignificant.

95. Although we hesitate to read too much into this result because the data set includes so few foreign firms, the proportion of foreign firms that are GPs is much higher than in the total sample, and our interview results indicate that foreign firms face different issues concerning the choice of organizational form than do domestic firms. See supra notes 88-89 and accompanying text (discussing the foreign firms).

96. The log is used because the figures on the average number of in-house counsel are skewed. The log operator minimizes the impact of this dispersion. Consider an example: Shearman \& Sterling represents six companies among the Fortune 250 with an average number of in-house counsel of 438. Morrison \& Cohen represents one company with an in-house counsel office of seventeen people. Using just the average number of in-house counsel implies that the information asymmetry between Shearman and its clients is twenty-five times less than the information asymmetry between Morrison $\&$ Cohen and its clients. This result seems unreasonable, and the log operator minimizes this difference. See Steve Choi \& Mitu Gulati, Choosing the Next Supreme Court Justice: An Empirical Ranking of Judicial Performance, 78 S. CAL. L. REV. 23, 72 (2004) (noting that the "use of the log transformation ... helps reduce the skewness in the distribution due to the superstar effect (resulting in a more normal distribution ... )").

97. FOREIGN does not appear in this table because, for the firms in this small dataset, FOREIGN perfectly predicted the choice of form. As a result, the logit model could not run with FOREIGN.

98. In addition, if information asymmetry causes firms to remain a GP and information asymmetry causes clients to increase the number of in-house counsel, then there is a simultaneity problem. In this case, treating the number of in-house counsel as an exogenous variable will lead to incorrect results. See GreEnE, supra note 77, at 652-53. We thank Allen Ferrell for bringing this fact to our attention. 
bined with insights from our interview data, the data suggest that firms are not retaining unlimited liability to signal quality to the market.

TABLE 10

Logit estimates

Number of obs $=39$

Wald chi2 $(5)=4.58$

Prob $>$ chi $2=0.4694$

Log pseudo-likelihood $=-14.783085 \quad$ Pseudo R2 $=0.1171$

\begin{tabular}{|c|c|c|c|c|c|}
\hline FORM & Coef. & $\begin{array}{l}\text { Robust } \\
\text { Std. Error }\end{array}$ & $\mathrm{z}$ & $\mathrm{P}>\mathrm{Z}$ & [95\% Conf. Interval] \\
\hline LAWYERS & .000452 & .0028821 & 0.16 & 0.875 & $\begin{array}{ll}.0051969 & .0061009 \\
\end{array}$ \\
\hline OFFICES & .1687124 & .1009903 & 1.67 & 0.095 & $\begin{array}{ll}-.029225 & .3666499 \\
\end{array}$ \\
\hline GROWTH & -.1049959 & .0865421 & -1.21 & 0.225 & $-.2746154 \quad .0646235$ \\
\hline $\begin{array}{l}\text { INHOUSE } \\
\text { AVG }\end{array}$ & -.5037849 & .6437803 & -0.78 & 0.434 & $-1.765571 \quad .7580012$ \\
\hline $\begin{array}{l}\text { INHOUSE } \\
\text { TOTAL }\end{array}$ & -.0007108 & .0008888 & -0.80 & 0.424 & $\begin{array}{ll}.0024528 & .0010312\end{array}$ \\
\hline _CONS & 4.365533 & 3.190948 & 1.37 & 0.171 & $\begin{array}{ll}-1.888609 & 10.61968 \\
\end{array}$ \\
\hline
\end{tabular}

\section{Testing the Theories Revisited-A Duration Analysis}

\section{a. Motivation for the Duration Analysis}

The duration model is a time event study that measures the time that has elapsed before a certain event occurs. ${ }^{99}$ Unlike the logit model, which analyzes a firm's choice of form at a particular moment in time, the duration model permits an analysis of choice of form as it changes over time. In other words, whereas the logit model asks whether there are significant differences between firms that are GPs and firms that are LLPs, the duration model asks whether there are significant differences in the speed with which firms with certain characteristics became LLPs. Unlike the logit model, the duration model thus allows us to examine whether the length of time it takes a firm to switch from the GP to LLP form correlates with the variables that economists predict are important in determining the choice of form. Did, for example, larger firms or more geographically dispersed firms adopt LLP status more quickly than small firms with only one office? This question can only be answered by looking at the firms over time.

The duration model provides two other benefits as well. First, the logit models discussed above may suffer from a problem of endogeneity. The logit model assumes, for example, that the number of lawyers is exogenous. In other words, it assumes that the number of lawyers is not influenced by the choice of form.

99. For complete and more technical treatments of the duration model, see JEFFREY M. Wooldridge, ECONOMETRIC ANAlysis of Cross Section AND PANel Data 685-715 (2002); Nicholas M. Kiefer, Economic Duration Data and Hazard Functions, 26 J. ECON. LiTERATURE 646 (1988). 
As noted above, the hypothesis we would like to test is that the number of lawyers in the firm significantly impacts the probability that the firm will limit its liability. ${ }^{100}$ However, it is also possible that the firm's choice of form determines the number of lawyers. In other words, an LLP may have more lawyers precisely because it has limited its liability. If this is the case, then it is the choice of form that drives the number of lawyers, rather than the other way around as hypothesized. This same type of endogeneity problem is possible with the variables OFFICE, GROWTH, and FOREIGN as well, rendering the logit estimates potentially unreliable.

To address this problem, we gathered data on the number of offices and the number of lawyers from 1994 to 2003. Next, we used the fact that each firm filed for LLP status on a different date to control for endogeneity.

To see how this works, consider Skadden Arps Slate Meagher \& Flom LLP. Skadden filed for LLP status on May 25, 2001. The duration analysis asks whether the number of lawyers at Skadden in any one year influences the probability that Skadden files for LLP status in that same year, assuming that Skadden had not filed for LLP status up to that point in time. The number of lawyers at Skadden after the filing date thus plays no role in the analysis, as the duration analysis ends with the filing date. The temporal nature of the analysis mitigates the chance of endogeneity. In contrast to the logit model (which is based on a snapshot of firm characteristics), endogeneity will be a problem in the duration model only if the firm adds or subtracts lawyers in anticipation of the switch in form. ${ }^{101}$

The final benefit of the duration model relates to sample size. Although we collected data on every New York law firm listed in Martindale-Hubble as having twenty-five or more lawyers, the logit models are based on a small sample size. The duration analysis takes the same small sample and expands it by looking at each firm over a ten-year period. This increase in the sample size gives us more confidence in the results.

b. Description of Methodology

i. The Duration Model

The duration model originated in medical studies in which researchers desired to study the length of time a patient survives after a particular treatment. ${ }^{102}$ For this reason, the duration model is sometimes referred to as a survival model. In a duration model, the key variable is

100. For reasons discussed supra note 23, we did not predict whether this impact would be positive or negative.

101. Mario A. Cleves et al., An Introduction to Survival Analysis Using Stata 166 (2004) (noting that, in duration analysis, "researchers often ignore anticipation or delay effects").

102. WOOLDRIDGE, supra note 99, at 685. 
the hazard rate. The hazard rate is the probability that the event of interest occurs, given that the event has not occurred up to that point in time. ${ }^{103}$

To see this more clearly, consider an economic problem that has been subject to duration analysis: unemployment. ${ }^{104}$ In a duration analysis of unemployment, the event of interest is finding a job. The hazard rate for a particular week is the probability the person finds employment that week, given that the same individual has been unemployed for the previous weeks. One policy issue is how unemployment benefits affect the hazard rate. ${ }^{105}$ If unemployment benefits decrease the hazard rate, this means that more benefits increase the chance of continued unemployment.

In this same context, a researcher might be interested in whether certain characteristics of the unemployed person influence the hazard rate, for example, whether the person is male or female. These sorts of characteristics are called covariates. Some covariates change over time. Unsurprisingly, these covariates are called time-varying covariates. In the unemployment context, an example of a time-varying covariate is underlying economic conditions.

\section{ii. Application to the Choice of Organizational Form}

In our model, the event of interest is the switch from the GP form to the LLP form. Our covariates are the number of lawyers and the number of offices in any year and whether the firm is a foreign or domestic firm, as we are interested in whether these characteristics impact the probability that the firm switches form, given that it had not switched form before. Based on the economic theories discussed above in Part II, we would predict that a firm's number of lawyers and number of offices will impact the speed with which the firm switches form. That is, the hazard rate (the probability of switching to the LLP form at a specific moment, conditional on the firm not switching up to that point) will change with the number of lawyers and the number of offices. Both OFFICES and LAWYERS are time-varying covariates in the analysis. FOREIGN, by contrast, is a constant covariate.

\section{iii. Results}

The starting date of the study is 1994-the year that New York's LLP statute became effective. Although the model is based on 110 firms,

103. See Kiefer, supra note 99, at 649

104. For an early study of this sort, see Tony Lancaster, Econometric Methods for the Duration of Unemployment, 47 ECONOMETRICA 939 (1979).

105. See Gerard J. van den Berg, Search Behaviour: Transitions to Non-Participation and the Duration of Unemployment, 100 ECON. J. 842, 855-56 (1990) (discussing unemployment benefits as a policy lever). 
only 90 firms switched from the GP form to the LLP form during the course of the study. ${ }^{106}$

Each firm has multiple observations. For example, we observe the number of lawyers and the number of offices for Kelley Drye \& Warren LLP in 1994, 1995, and 1996. We discarded all observations after Kelly switched form in 1996, and, in effect, exited the study.

We used the Cox method for estimating the model. ${ }^{107}$ For ease of interpretation, the estimates on LAWYERS, OFFICES, and FOREIGN are reported as hazard ratios. Hazard ratios have a simple interpretation. If the hazard ratio equals two, this means that a one-unit increase in the covariate increases the hazard rate by $100 \% .{ }^{108}$ So, for example, if the number of lawyers increases by one and the estimated hazard ratio is two, this means that, at any point in time, a law firm with 200 lawyers has twice the conditional probability of adopting LLP status as a law firm with 199 lawyers. ${ }^{109}$ If the hazard ratio equals one, a one-unit increase in the covariate of interest has no impact on the hazard rate.

Table 11 reports the results. We cannot reject the hypothesis that LAWYERS and OFFICES have no effect on the probability of a switch in form from a GP to an LLP (i.e., that the hazard ratio for each of these variables is equal to one.) In other words, we cannot reject the possibility that, contrary to theory, the number of lawyers and the number of offices play no role in a law firm's decision to limit its liability. This finding provides another check and adds robustness to the logit model findings presented above.

\section{TABLE 11}

Cox regression - Breslow method for ties

No. of subjects $=111$

Number of obs $=585$

No. of failures $=90$

Log likelihood $=-371.20846$

\begin{tabular}{|l|l|l|l|ll|l|}
\hline & Haz. Ratio & Std. Error & $\mathrm{z}$ & $\mathrm{P}>|\mathrm{z}|$ & \multicolumn{2}{l|}{ [95\% Conf. Interval] } \\
\hline LAWYERS & .9997929 & .0007201 & -0.29 & 0.774 & .9983825 & 1.001205 \\
\hline OFFICES & 1.024761 & .0359544 & 0.70 & 0.486 & .95666 & 1.09771 \\
\hline FOREIGN & .6540692 & .340994 & -0.81 & 0.415 & .235427 & 1.817152 \\
\hline
\end{tabular}

106. The model is based on only 110 firms, not 118 , because complete data were unavailable for eight firms.

107. The Cox model assumes that the "covariates multiplicatively shift the baseline hazard function." See ClEVES ET AL., supra note 101, at 121. The baseline hazard function is the hazard function when all the covariates equal zero. Id. The Cox method is a common way to estimate a duration model. We also estimated the effects using various other models, which make assumptions about the distribution of the hazard function. These models include, for example, the exponential and Weibull models. Id. at 213-50. Neither LAWYERS nor OFFICES was significant in any formulation of the model.

108. For a more detailed discussion of hazard ratios, see $i d$. at 122-27.

109. We also did the same analysis but changed the units on lawyers. With the changed units, a one-unit increase meant an increase of ten lawyers at the firm. Under this modification, we could not reject the possibility that the hazard ratio equals one. 


\section{INTERVIEW DATA}

We sought clarification and confirmation of the implications of our empirical results through a series of interviews with individuals active in and knowledgeable about the choice of organizational form by New York law firms. Specifically, we interviewed: (1) partners at law firms in our sample who had been involved in their firm's decision regarding organizational form; (2) legal consultants, who advise law firms on a variety of matters, including the choice of organizational form; and (3) insurers, who base malpractice liability insurance rates on a variety of factors thought to correlate with the probability of a malpractice judgment and, thus, collect data from law firms regarding those factors. ${ }^{110}$

\section{A. Law Firm Partners}

\section{Methodology}

In order to shed light on the results of our empirical analysis, we interviewed partners at many of the law firms in our sample. We interviewed partners at many firms across a range of sizes and practice areas that had opted for LLP status. More importantly, we interviewed at least one partner at every law firm in our sample with more than fifty lawyers that had chosen to remain a GP. To add depth and understanding to our analysis, we also interviewed a limited number of in-house counsel and partners at law firms that are not in our sample, but that we felt were sufficiently similar to our sample of firms to provide useful information concerning issues relating to the choice of organizational form by firms in our sample. ${ }^{111}$ In total, we interviewed seventy-five partners at sixty firms.

Interviewees were encouraged to freely discuss the choice of organizational form at their firm, without prompting or leading from the interviewer. When necessary, interviewees were prompted to discuss particular issues of interest to the authors through a list of questions. The list of questions designed for GP partners is attached to this article as Appendix E. The list of questions designed for LLP partners is attached to this article as Appendix F.

110. All interview subjects were ensured confidentiality and are not identified by name or firm name in this article. For purposes of verifiability, redacted interview notes are available from the authors.

111. As an example, one large foreign firm whose main domestic office is in New York did not appear in our sample due to a quirk in the method by which the firm lists with Martindale-Hubble. We felt that partners at this firm faced issues regarding the choice of organizational form sufficiently similar to those faced by firms in our sample to provide useful information. 


\section{Findings}

Although the explanations offered for the choice to remain a GP vary across firms and law firm cultures are undoubtedly idiosyncratic, several general themes arose from our discussions with law firm partners. First, neither apathy nor lack of attention to the costs and benefits of LLP status seem to explain the choice of organizational form in any of the firms in our sample. Second, the most frequently cited issues that arose in connection with the LLP debate at most firms were: concerns over lost collegiality, concerns over the perceived negative signal to clients associated with limited liability, whether a sufficient number of the filing firm's peer firms had filed, the "Arthur Andersen effect," and the connection between limited liability and lock-step compensation. In addition, nearly every partner that we interviewed indicated a belief that the ultimate movement of law firms to limited liability forms was inevitable. This was true even among partners at firms that had decided to remain a GP, at least temporarily.

Third, intra-firm economics had caused a handful of firms to struggle with the move to a limited liability entity, although each of those firms was eventually able to overcome that struggle and file for LLP status. Finally, some law firm partners cited the size, decentralization, and specialization of modern law firms as relevant factors motivating the decision to become an LLP.

\section{a. Ruling Out Apathy and Lack of Sophistication}

It is worth noting at the outset that neither lack of sophistication, failure to appreciate the costs and benefits of limited liability, nor simple apathy can explain the lack of movement into LLPs by those New York law firms that remain a GP. As is evident from the many large and successful firms listed in Appendix A as a GP, partners at the GP firms are quite sophisticated. Our interview data reveal that, in these firms, the partners have debated (and rejected) LLP status. The existence of the debate reveals that: (1) partners know about LLP status, and (2) the LLP is not the preferred choice for every partner. At least some partners perceive costs as well as benefits to the LLP form.

This is not to imply that the conversion to a limited liability entity entails no transaction costs for law firms. Simply garnering agreement from, in some cases, hundreds of busy and opinionated law firm partners doubtless can be difficult. However, in almost every case the reason for this difficulty stems from the fact that many law firm partners perceive real costs to the conversion to an LLP form, as discussed throughout this Part IV. 
In addition, some firms did attribute their slow movement to the LLP form to the fact that limiting liability "simply was not a priority" for the firm. ${ }^{112}$ However, at every firm we spoke to, this view changed substantially after the Arthur Andersen bankruptcy, as discussed in more detail in Part IV.A.2.e.

b. Collegiality

Every partner we interviewed identified fears regarding a loss in firm collegiality as an issue that arose in their firms' debates over whether to become an LLP. ${ }^{113}$ When pressed to describe exactly what was meant by a loss of collegiality, it became clear that "collegiality" takes on several different meanings.

For some partners, particularly older partners, a loss of collegiality resembled a form of nostalgia. These partners often lamented the increasing commercialization of law practice and yearned for the days when all partners knew and trusted each other and all clients knew and trusted their legal counsel.

At other firms, concerns over lost collegiality took on a decidedly economic cast. A commonly asserted fear was that partners would hesitate to advise fellow partners or pitch in on matters if doing so would create additional liability risk. A handful of partners at firms that had become LLPs believed that this fear had been well-founded at their firm and that certain partners now avoided helping out on other partners' projects, out of a desire to limit their personal exposure. ${ }^{114}$ Most partners, however, indicated that becoming an LLP had not impacted in any way the relations among partners. As stated by one law firm partner, "Partners who were uncollegial before [the firm became an LLP] are still uncollegial and partners who were collegial before are still just as collegial [after the firm became an LLP]."

\section{c. Signaling}

Our interviews with law firm partners revealed that, at nearly every firm, partners feared the negative signal that any limitation on personal liability might send to their clients and competitors. This fact was particularly true when very few of the firm's competitor firms had opted to limit their liability. As stated by one law firm partner, "At the time we

112. Confidential interview with law firm partner in New York, N.Y. (July 13, 2004) (interview notes on file with authors).

113. Confidential interviews with law firm partners (interview notes on file with authors); see also Anthony Lin, After Enron, Firms Rethink Partnership, 227 N.Y. L.J. 1, 1 (2002) (quoting an unnamed partner at a major New York law firm as stating that his firm deadlocked over the decision of whether to become an LLP because of the "tremendous fear that the partnership would lose its collegiality").

114. Confidential interviews with law firm partners (interview notes on file with authors).

115. Confidential interview with law firm partner in New York, N.Y. (July 12, 2004) (interview notes on file with authors). 
first debated becoming an LLP, none of the firms that we consider similar to us had limited their liability. We didn't want to be path breakers on this." 116

At the same time, as more firms within a given cohort opt for LLP status, the perceived negative signal associated with limited liability diminishes, and the arguments in favor of limited liability are more persuasive. As stated by one partner, "We're currently reconsidering the issue and my prediction is that we'll switch [to an LLP] at some point in the near future. Now that most of the other firms like us have switched, the arguments against it seem weaker."117

Interestingly, it is not at all clear that this fear is well-founded. Every LLP partner that we spoke to believed that the firm's relations with clients had not been altered by the decision to become an LLP.

\section{d. The Importance of Cohorts}

Our interview data reveal that law firms are extraordinarily conservative and are reluctant to take actions that may distinguish them in a negative manner from their competitor firms. This fact is especially true of the large, elite law firms that we interviewed. For those firms who were slow to file for LLP status (as noted, this is true of the majority of elite firms), one of the most commonly cited rationales for the firm's hesitation in filing was the fact that the firm did not want to file until a sufficient number of peer firms had also decided to file. ${ }^{118}$ Similarly, in addition to the Arthur Andersen effect, the most commonly cited motivation behind the eventual decision to file was the fact that a sufficient number of peer firms had finally determined to file. Our interview data also reveal that law firm partners were in regular communication with peer firms about the decision to file and, in some cases, coordinated the timing of their filings. ${ }^{119}$

\section{e. The Arthur Andersen Effect}

In our interviews with partners at firms that had recently chosen to limit their liability or were currently considering whether to do so, one factor was mentioned repeatedly as being relevant to the firm's decision: the demise of Arthur Andersen. ${ }^{120}$ This fact was especially true at large,

116. Confidential interview with law firm partner in New York, N.Y. (Mar. 17, 2004) (interview notes on file with authors).

117. Confidential interview with law firm partner in New York, N.Y. (June 2, 2004) (interview notes on file with authors).

118. Confidential interviews with law firm partners (interview notes on file with authors).

119. Id.

120. Id.; see also Lin, supra note 113, at 1 (noting that "[i]n light of the potentially crippling liability faced by Arthur Andersen, Vinson \& Elkins and Kirkland \& Ellis for their roles in the collapse of Enron Corp., major law firms are considering again whether to form themselves into limited liability partnerships"). 
elite law firms, many of whom only opted for LLP status after 2001. Apparently, for many of these firms, the threat of a liability judgment that exceeded the firm's malpractice insurance seemed relatively remote. ${ }^{121}$ Given the perceived losses associated with limited liability, many firms simply felt that the benefits of LLP status were insufficient to overcome the costs. ${ }^{122}$

For many firms, however, this perception changed with the trial and subsequent bankruptcy of Arthur Andersen. Suddenly, the possibility of a liability judgment that would not only exhaust the firm's liability insurance, but its partners' personal assets as well, seemed very real. Apparently, the fact that a firm as large and reputable as Arthur Andersen could simply disintegrate was a sobering experience for many law firm partners, and one that changed their outlook on limited liability. In fact, several partners asserted their belief that their firms never would have switched to an LLP had the Enron and Arthur Andersen debacles not occurred. ${ }^{123}$

\section{f. Ruling Out the Monitoring Theory}

Many, if not most, of the law firm partners with whom we spoke were familiar with the theory that placing each partner's personal liability at stake for the blunders of every partner induces more careful monitoring among partners. However, law firm partners with whom we spoke tended to scoff at this theory of partnership form. First, most partners cited the size, decentralization, and specialization of the modern law firm as a factor that prevented the effectiveness of such attempts to monitor. ${ }^{124}$ In addition, many partners were offended by the notion that partners fail to attempt such monitoring to the best of their ability absent the threat of full personal liability. ${ }^{125}$ As noted by most partners, the fear of a liability judgment so large that it wipes out the partnership's assets and insurance is not the factor that motivates careful legal work and monitoring of fellow partners and associates. Instead, it is concern with maintaining the firm's reputation and maximizing the firm's billable rates that motivates monitoring of partners by other partners. ${ }^{126}$

121. Confidential interviews with law firm partners (interview notes on file with authors); see also Lin, supra note 113 (quoting Ward Bower, a principal at the law firm consultancy Altman Weil, as saying that, prior to Enron, many law firms assumed that malpractice was an insurable risk, but that “[y]ou can't insure against 10-figure liability").

122. Confidential interviews with law firm partners (interview notes on file with authors).

123. Confidential interviews with law firm partners (interview notes on file with authors).

124. Confidential interviews with law firm partners (interview notes on file with authors); see also infra notes 131-33 and accompanying text (discussing size, decentralization, and specialization as impacting the choice of organizational form).

125. Confidential interviews with law firm partners (interview notes on file with authors).

126. Id. 


\section{g. The Partnership Penalty}

Despite the ongoing debate within many law firms regarding the choice of organizational form, the interview data reveal a feeling among law firm partners that those partners pushing to remain a GP may some day lose the intra-firm debate. At that time, the remaining GP firmslike most of their competitors-will opt for a limited liability form of some sort.

These statements, combined with the other interview data discussed in this Part IV, cause us to conclude in Part V.A of this article that, if the GP form continues to exist, it will not be as an organizational form voluntarily chosen by firm participants after weighing the costs and benefits. Instead, we predict that the only function of the GP form in the coming years will be as a penalty default rule that forces parties contemplating the formation of a business or professional enterprise to reveal relevant information to courts and interested third parties. At the same time, however, the fact that many law firm partners have aggressively pushed to remain a GP indicates that, at least for many law firm partners, the benefits of unlimited liability are real, a phenomenon explored in subparts $b-d$ of this section.

\section{h. The Lock-Step Connection}

The decision to switch from a GP to an LLP seemed particularly difficult at firms that still practiced some version of lock-step compensation. As noted both by partners at lock-step firms and by those that are not, the concept of differentiated personal liability is inconsistent with the foundational principal at a lock-step firm that all of the partners "sink or swim together." 127 In addition, because partners at a lock-step firm can only succeed if every other partner succeeds, a willingness to pitch in and help out partners on any project on which help is needed is especially valued. ${ }^{128}$

\section{i. Intra-Firm Economics}

Our interviews revealed that intra-firm economics had caused a handful of the law firms in our sample to struggle with the move to a limited liability vehicle, although in every case the firm was eventually able to overcome those issues and adopt the LLP form. According to some partners we interviewed, problems with renegotiating the division of profits within the firm before moving to a limited liability entity caused negotiations over the move to LLP status to stall. ${ }^{129}$

127. Confidential interviews with law firm partners (interview notes on file with authors)

128. Confidential interviews with law firm partners (interview notes on file with authors); see also supra notes 113-15 and accompanying text (discussing firm collegiality).

129. Confidential interviews with law firm partners (interview notes on file with authors). 
Although LLP law permits partners to use their old GP agreement without modification to govern their relationship once they become an LLP, at least some firms feel that modification is necessary. This is because the GP form requires partners to share all profits and all liability risks, despite the fact that some partners are in high-risk, high-return practice areas. Presumably, GP agreements are premised on the notion that such high-risk, high-return partners are willing to give up some portion of those returns, in exchange for the opportunity to share the risk of personal liability with all firm partners.

Once a firm adopts limited liability status, however, partners are no longer sharing the risk of personal liability for the acts of fellow partners. As such, some high-risk, high-return partners expect to receive a greater share of the division of firm profits if the firm becomes an LLP. Debates over whether and how much more some partners would receive under an LLP form and how much other partners would, in turn, be forced to give up caused some law firms to struggle with the move to LLP form, in some cases for as long as a year or two. ${ }^{130}$

\section{j. Size, Specialization, and Decentralization}

Although neither LAWYERS nor OFFICES were significant predictors of the choice of organizational form in our logit regression, ${ }^{131}$ law firm partners frequently cite the increasing size, decentralization, and specialization of the modern law firm as a factor impacting the choice to limit the partners' personal liability. ${ }^{132}$ To many partners, the notion that a trust and estate partner in Texas could or would more carefully monitor a bankruptcy partner in New York simply because of personal liability fears is absurd, given the realities of modern law firm life. ${ }^{133}$

\section{k. Summary}

As noted by law firm partners, no single factor is a determinant of the choice of organizational form. ${ }^{134}$ Instead, as stated by many partners, a "confluence" of events has dictated the decision. Those events include the number of similarly situated firms that have chosen to become LLPs,

130. Confidential interviews with law firm partners (interview notes on file with authors); see also Lin, supra note 113, at 1 (quoting Kenneth J. Laverriere, a Sherman \& Sterling partner involved in the organizational form decision, as stating that Sherman's negotiations over the move to LLP status took several months or longer, in part because of concerns over the division of profits under the LLP structure when some partners were in high-risk, high-return practice areas).

131. See supra notes $77-78$ and accompanying text.

132. Confidential interviews with law firm partners (interview notes on file with authors).

133. Confidential interviews with law firm partners (interview notes on file with authors); see also Richard C. Reuben, Added Protection, 80 A.B.A. J., 54, 56 (1994) (quoting Robert R. Keatinge, Chair of the ABA Business Law Section Partnership Committee's Subcommittee on Limited Liability Companies, as stating " $[\mathrm{w}]$ hen you think about it, there is nothing I as a tax lawyer can do that will protect against someone from another department within the firm screwing up a water law issue").

134. Confidential interviews with law firm partners (interview notes on file with authors). 
rising liability fears associated with Arthur Andersen, larger transaction sizes, more frequent malpractice awards, the failure of malpractice insurance to keep pace with these risks, and the intricacies of internal firm economics and culture. ${ }^{135}$

\section{B. Law Firm Consultants}

Law firm consultants work for consultancy firms that advise law firms on a variety of matters relating to law firm structure, operation, and profitability, including the choice of organizational form. Our interviews with law firm consultants reinforced the information gathered through interviews with law firm partners.

\section{Law Firm Insurers}

Insurance companies insure business and professional enterprises, including law firms, against a variety of risks, including the risk of liability arising from legal advice rendered to clients. In determining what rates to charge law firms for such insurance, insurance companies consider a variety of factors that are thought to correlate with an increased risk of such liability.

If the theories proposed by economists and legal scholars that assert that unlimited liability results in the provision of higher-quality legal services are true, then insurance companies should charge GPs lower premiums than LLPs, in order to reflect the decreased risk of liability among GP firms. ${ }^{136}$ In other words, if unlimited liability really causes partners to better monitor each other, then that reduced liability risk should be reflected in lower insurance rates.

Our interviews with law firm insurers reveal that insurance companies do not consider organizational form in setting liability insurance premiums. ${ }^{137}$ This is supported by our interviews with law firm partners. Although not every partner we interviewed was familiar with the firm's insurance rates, those who were indicated that the decision to become an LLP had been made after consultation with the firm's insurance com-

135. Id.

136. This is in contrast to theories such as signaling, which predict higher profitability but not a lower liability risk, and profit-sharing, which predicts higher per partner profitability, but not a better product.

137. Confidential interviews with insurers (interview notes on file with authors); see also Jett Hanna, Legal Malpractice Insurance and Limited Liability Entities: An Analysis of Malpractice Risk and Underwriting Responses, 39 S. TEX. L. REV. 641, 645 (1998) (stating that "[o]nly if the insurer provides coverage for prior affiliations of the attorney constituents of a limited liability entity will there conceivably be a reduced incident of loss as a result of limited liability status"); Robert W. Hillman, The Impact of Partnership Law on the Legal Profession, 67 FoRDHAM L. REV. 393, 409 (1998) (noting that "LLP status does not reduce the liability of the partnership itself, which means the need for insurance underwriters to insist on implementation of monitoring mechanisms is largely unaffected by conversion of a firm from a general partnership into an LLP"). 
pany and had not altered liability insurance premiums. ${ }^{138}$ Accordingly, insurance companies apparently do not believe that unlimited liability causes law firms to render higher quality legal services. Unless insurance companies have erred in their actuarial calculations or have failed to consider the possible connection between organizational form and liability risk, this fact undermines the economic theories asserting that unlimited liability results in a better legal product.

\section{CONCLUSION: EXPLAINING THE NEW YORK LAW FIRM MARKET}

In today's litigious age, legal practitioners understandably are concerned with the costs associated with liability, including liability for legal malpractice. According to many sources, malpractice actions against law firms are increasingly common and judgments are becoming larger. ${ }^{139}$ In addition, malpractice insurance is more expensive, covers less, and by all accounts has not kept pace with the increased liability risks associated with larger transaction sizes and volatile markets. ${ }^{140}$ This is particularly true in high-risk legal fields, such as banking, securities, and other heavily regulated industries. ${ }^{141}$ As a result, it is not uncommon today to see law firm bankruptcies or law firm partners who incur personal liability as a result of malpractice judgments or other law firm debts. ${ }^{142}$

An analysis of the empirical and interview data collected for this article, however, indicates that, at least with respect to New York law firms, the costs and benefits of limited liability are more complicated than either the academics or legal practitioners would like to believe. The rapid movement of firms into the LLP structure and the failure of

138. Confidential interviews with law firm partners (interview notes on file with authors).

139. ABA Standing Committee on Lawyers' Professional Liability, The Profile of LEGAL MALPRACTICE ClAIMS: 1996-1999 (2001) (finding that insurers expect more frequent and severe lawsuits against attorneys following economic downturns); ROLAND E. MALLEN \& JEFFERY M. SMITH, LEGAL MALPRACTICE $§ 1.6$ (5th ed. 2000) (noting that the rise in malpractice suits is proportionally larger than the increase in the number of practicing attorneys); Carol R. Goforth, Limiting the Liability of General Partners in LLPs: An Analysis of Statutory Alternatives, 75 OR. L. REV. 1139, 1142 (1996); Johnson, supra note 6, at 85, 87; Manuel R. Ramos, Legal Malpractice: The Profession's Dirty Little Secret, 47 VAND. L. REV. 1657, 1674-80 and App. B \& D at 1741-42, 1749-50 (1994) (demonstrating that malpractice claims have sharply increased).

140. InSt. OF MGMT. \& Admin., MANAGing Risk: What LAW Firms Must Do to CONTROL LiABILITY INSURANCE COSTS (2003), available at 2003 WL 2068161 (stating that firms, especially larger firms, are likely to see substantial rises in liability insurance rates); Earl Ainsworth, Malpractice Insurance: A High Priced Headache for Lawyers, N.J. LAw., Mar. 10, 2003, at A2; Rita Henley Jensen, For Third Straight Year Malpractice Rates Rise Again, NAT'L. L.J., Apr. 12, 1993, at 2-3; Johnson, supra note 6, at 88; Susan Saab Fortney, Legal Malpractice Insurance: Surviving the Perfect Storm, 28 J. LEGAL PROF. 41, 41-42 (2003-2004) (citing various factors that "have contributed to fewer insurers writing legal malpractice insurance, limited coverage offered by those insurers who remain in the market, and dramatic premium increases for those policies that are available"); see also Confidential interviews with law firm partners (interview notes on file with authors); Confidential interviews with law firm insurers (interview notes on file with authors).

141. Johnson, supra note 6 , at 88 .

142. Coates, supra note 28, at 1352 tbl.3 (discussing law firm dissolutions); Johnson, supra note 6, at $88-89$. 
the empirical tests in Part III of this article to return the results predicted by existing partnership theories cast doubt on arguments that the unlimited liability of the GP form provides the unqualified benefits asserted by many researchers. At the same time, the fact that a substantial number of large and sophisticated law firms have opted to remain a GP despite the availability of a quick, inexpensive, and easy alternative undermines the arguments of legal practitioners who suggest that the GP form provides no benefits to those considering the formation of a business or professional enterprise.

\section{A. The Future of GPs: A Penalty Partnership Theory}

Our empirical results indicate that most New York law firms have, in fact, abandoned the GP regime and our follow-up interviews with law firm partners whose firms are represented in our study indicate that the rest may at some point in time follow suit. The asserted reasons for each firm's choice of organizational form are telling and indicate that, for many partners, the perceived benefits of unlimited liability are real. At the same time, however, the interviews indicate that this view is changing, and that most of those interviewed believe that full movement into the LLP form is inevitable. If this is true, then the New York law firm market has not yet reached equilibrium.

Consistent with these views, we predict that, with the advent of the LLP form, if the GP form is to continue to exist in the future, it will not be as an organizational form voluntarily chosen after carefully weighing the costs and benefits. Instead, we predict that, as is the case with the New York law firms in our sample, parties in business and professional relationships will abandon the GP form altogether, and it will continue to exist primarily as a penalty default regime that forces the revelation of information to the state and interested third parties. Accordingly, we add a new theory of partnership to those already advanced by lawyers and economists: a penalty default theory of partnership.

The penalty default theory of partnership arises from the fact that the GP is the ultimate default regime for businesses operated by more than one person. If two or more parties run a business for profit and do nothing else, the GP default rules apply. ${ }^{143}$ The case law is full of situations where parties entered into a business and unintentionally ended up a partnership. ${ }^{144}$

143. See White Consol. Indus., Inc. v. Waterhouse, 158 F.R.D. 429, 434 n.7 (D. Minn. 1994) ("[W] hether a legally binding partnership has been formed is a question of fact which can be inferred from the partners' actions. We are aware of no requirement that, in order to verify its formation, a partnership agreement must be filed with the State."); Unif. P'ship Act $§ 6$ (1914), 6 U.L.A. (pt. I) (2001) (defining "partnership"); Unif. P’ship Act $\$ \$ 101(4), 202$ (1997), 6 U.L.A. (pt. I) (2001) (defining "partnership").

144. See Reddington v. Thomas, 262 S.E.2d 841, 843 (N.C. Ct. App. 1980); Bass v. Bass, 814 S.W.2d 38, 44 (Tenn. 1991); Howard Gault \& Son v. First Nat'l Bank of Hereford, 541 S.W.2d 235, 237 
We propose that the GP default rules may make sense-and may, in fact, be socially desirable-because they penalize parties who fail to formalize their arrangements, either by affirmatively choosing an organizational form that requires notification to the state, or through elaborate contractual drafting. In the terms familiar to contract law scholars, the entire general partnership regime may operate as an information-forcing default rule.

The state may desire such information-forcing from business and professional service firms for a variety of reasons. First, by forcing parties to file as LLPs, LLCs, or corporations, the state encourages the parties to acknowledge they are a business association. This recognition, then, pushes parties to explicitly resolve (or at least think about) many important issues - such as, for example, the division of profits-through careful negotiation and drafting. And this, in turn, reduces the information gathering burden on courts and creditors. ${ }^{145}$ Second, state notification of the existence of a for-profit firm enables the state to take certain actions with respect to that firm. For example, the state can more easily tax and regulate for-profit firms when it has been alerted to their existence. ${ }^{146}$

\section{B. Innovation and Diffusion: Status, Networks, and Signaling}

In addition, if the New York law firm market has not reached equilibrium, this leads to two questions: (1) why has full movement into the LLP form been so slow, and (2) why have some firms moved relatively quickly, while others have taken their time? Our interview data reveal that law firms will go to great lengths (in this case, risking full personal liability) in order to avoid being perceived in a negative light relative to firms that they consider competitors for prestige and clients. This finding is consistent with prior research on the importance of signaling and status when the quality of output is difficult for consumers to judge, ${ }^{147}$ and with research on herding behavior among law firms and other professionals. ${ }^{148}$ This insight is also consistent with prior research on network effects and

(Tex. Civ. App. 1976). On the formation of partnerships, see generally ALAN R. BROMBERG \& LARRY E. RIBSTEIN, BROMBERG AND RIBSTEIN ON PARTNERSHIP § 2.05 (2004).

145. For an article making a similar argument, see Larry E. Ribstein, Limited Liability Unlimited, 24 DEL. J. CORP. L. 407, 448-49 (1999).

146. See Ribstein, supra note 44 , at 223

147. Candace Jones, Signaling Expertise: How Signals Shape Careers in Creative Industries, in CAREER CREATIVITY: EXPlorations IN THE REMAKING OF WORK 209, 210 (Maury A. Peiperl et al. eds., 2002) (discussing the importance of signaling in the movie industry); Joel M. Podolny, A StatusBased Model of Market Competition, 98(4) AM. J. Soc. 829, 830-35 (1993) (discussing the importance of status as a signal of quality); Price, supra note 76, at 25 (stating that law firms decided to match Gunderson's salary increases because to fail to do so would signal that they were not a top tier firm).

148. See Ronald S. Burt, Social Contagion and Innovation: Cohesion Versus Structural Equivalence, 92 AM. J. Soc. 1287, 1326 (1987) (demonstrating that whether or not an individual adopts an innovation is a function of whether or not equivalent peers have done so); Price, supra note 76, at 5 (noting that professional organizations, especially law firms, tend to copy each other). 
innovation, as (at least for the elite firms) it is only after a sufficient number of peer firms have become an LLP that the benefits of limited liability are judged to outweigh the perceived costs. ${ }^{149}$

This finding also provides insight into two aspects of change and innovation that have interested lawyers and social scientists for some time, but which have received minimal empirical study: (1) how new standards are adopted by particular market actors, and (2) how those changes then diffuse throughout the market. ${ }^{150}$ Our data indicate that elite firms adopted the new LLP form far more slowly than did their less elite New York counterparts. Only after an exogenous shock - the Enron and Arthur Andersen debacles, along with other corporate scandals-prompted some "higher bracket" firms to file as LLPs did the elite firms feel comfortable making this move. In addition, our interview data reveal the mechanisms by which this diffusion occurred. Not only did firms observe and copy the organizational form of their peer group, they explicitly coordinated their actions so as to minimize any potential negative signal associated with differentiating themselves from their cohort in terms of organizational form. ${ }^{151}$

In short, markets in equilibrium are frequently studied by social scientists. The adoption of the New York LLP statute, however, provides a rare opportunity to study a market in flux. In 1994, the New York state legislature provided law firms with a viable alternative to the organizational form that most firms had been using for many years, in some cases, for centuries. An analysis of how the market responded to this change provides valuable insights into the mechanisms by which change occurs and spreads across a market.

149. See Stephen Choi \& Mitu Gulati, Innovation in Boilerplate Contracts: An Empirical Examination of Sovereign Bonds, 53 EMORY L.J. 929, 930-38 (2004) (recognizing that contracting parties often agree to suboptimal terms due to the equilibrium established by network externalities and discussing the methods by which standardized terms can change); Marcel Kahan \& Michael Klausner, Standardization and Innovation in Corporate Contracting (Or "The Economics of Boilerplate"), 83 VA. L. REV. 713 (1997) (describing the "learning externalities" and "network externalities" that arise with the common use of a contract term); Michael Klausner, Corporations, Corporate Law, and Networks of Contracts, 81 VA. L. REV. 757, 761 (1995) (suggesting that "when the use of a contract term becomes widespread, its value may rise"); Robert B. Ahdieh, Cueing Transition in Sovereign Debt Contracts: Network Effects, Coordination Games, and Focal Points in the Choice of Mandate Versus Contract, at 19-22 (Emory Pub. Law Research Paper No. 03-23, 2004) (describing the network benefits that can arise from corporate contracting). But see Larry E. Ribstein \& Bruce H. Kobayashi, Choice of Form and Network Externalities, 43 WM. \& MARY L. REV. 79, 128 (2001) (finding that network externalities -in the form of an established body of law-have only a minimal impact on the choice of organizational form); Michael J. Whincop, An Empirical Analysis of the Standardisation of Corporate Charter Terms: Opting Out of the Duty of Care, 23 INT'L. REv. L. \& ECON. 285, 285-86 (2003) (finding similar evidence with respect to the evolution of Australian charter provisions).

150. See W. Scott Frame \& Lawrence J. White, Empirical Studies of Financial Innovation: Lots of Talk, Little Action?, 42(1) J. ECON. LiTERATURE 116, 121 (2004) (lamenting the lack of empirical research on the impact of network effects on innovation).

151. Confidential interviews with law firm partners (interview notes on file with authors); see also Joseph Farrell \& Garth Saloner, Coordination Through Committees and Markets, 19 RAND J. ECON. 235,235 (1988) (studying the function of standardization committees in achieving coordination). 


\section{APPENDIX A}

\begin{tabular}{|c|c|c|c|c|c|}
\hline FIRM & FORM & DATE & LAWYERS & OFFICES & GROWTH \\
\hline $\begin{array}{l}\text { Aaronson Rappaport } \\
\text { Feinstein \& Deutsch, } \\
\text { LLP }\end{array}$ & LLP & $01 / 03 / 95$ & 58 & 2 & 6.5 \\
\hline $\begin{array}{l}\text { Abelman Frayne \& } \\
\text { Schwab }\end{array}$ & GP & & 29 & 1 & 4.9 \\
\hline Afridi \& Angell LLC & $\mathrm{LC}$ & $07 / 01 / 02$ & 30 & 6 & \\
\hline $\begin{array}{l}\text { Amster, Rothstein, \& } \\
\text { Ebenstein }\end{array}$ & LLP & $05 / 19 / 03$ & 43 & 1 & 3.4 \\
\hline $\begin{array}{l}\text { Anderson Kill \& Olick, } \\
\text { PC }\end{array}$ & $\mathrm{PC}$ & $05 / 04 / 73$ & 121 & 6 & \\
\hline $\begin{array}{l}\text { Barnes, Richardson \& } \\
\text { Colburn }\end{array}$ & GP & & 27 & 3 & -0.1 \\
\hline $\begin{array}{l}\text { Barry, McTiernan \& } \\
\text { Moore }\end{array}$ & GP & & 30 & 3 & 3.3 \\
\hline $\begin{array}{l}\text { Bernstein Litowitz Ber- } \\
\text { ger \& Grossmann LLP }\end{array}$ & LLP & $09 / 28 / 95$ & 34 & 4 & 13.8 \\
\hline Bivona \& Cohen, P.C. & $\mathrm{PC}$ & $01 / 10 / 79$ & 37 & 5 & \\
\hline $\begin{array}{l}\text { Borah, Goldstein, Alt- } \\
\text { schuler, Schwartz \& } \\
\text { Nahins, P.C. }\end{array}$ & $\mathrm{PC}$ & $11 / 14 / 79$ & 45 & 1 & \\
\hline $\begin{array}{l}\text { Brauner Baron } \\
\text { Rosenzweig \& Klein, } \\
\text { L.L.P. }\end{array}$ & LLP & $12 / 23 / 94$ & 28 & 1 & -0.6 \\
\hline $\begin{array}{l}\text { Brown Raysman Mill- } \\
\text { stein Felder \& Steiner } \\
\text { LLP }\end{array}$ & LLP & $05 / 24 / 95$ & 220 & 5 & 19.2 \\
\hline $\begin{array}{l}\text { Cadwalader Wicker- } \\
\text { sham \& Taft LLP }\end{array}$ & LLP & $02 / 26 / 03$ & 411 & 5 & 6.2 \\
\hline $\begin{array}{l}\text { Cahill Gordon \& Rein- } \\
\text { del LLP }\end{array}$ & LLP & $04 / 29 / 03$ & 225 & 3 & 1.9 \\
\hline $\begin{array}{l}\text { Carter Ledyard \& Mil- } \\
\text { burn LLP }\end{array}$ & LLP & $11 / 14 / 02$ & 118 & 3 & 4.5 \\
\hline $\begin{array}{l}\text { Chadbourne \& Parke } \\
\text { LLP }\end{array}$ & LLP & $08 / 08 / 95$ & 428 & 7 & 4.2 \\
\hline $\begin{array}{l}\text { Cleary Gottlieb Steen \& } \\
\text { Hamilton }\end{array}$ & GP & & 798 & 12 & 5.7 \\
\hline Clifford Chance US LLP & LLP & $01 / 28 / 98$ & 3500 & 32 & 19.9 \\
\hline $\begin{array}{l}\text { Cohen, Weiss and Simon } \\
\text { LLP } \\
\end{array}$ & LLP & $12 / 02 / 99$ & 31 & 1 & 0.8 \\
\hline Condon \& Forsyth LLP & LLP & $05 / 07 / 98$ & 51 & 3 & 3.8 \\
\hline $\begin{array}{l}\text { Conway, Farrell, Curtin } \\
\text { \& Kelly, P.C. }\end{array}$ & $\mathrm{PC}$ & $01 / 05 / 71$ & 38 & 3 & \\
\hline Cooper \& Dunham LLP & LLP & $12 / 28 / 94$ & 38 & 1 & 3.2 \\
\hline Coudert Brothers LLP & LLP & $09 / 05 / 01$ & 630 & 25 & 7.9 \\
\hline $\begin{array}{l}\text { Cowan, Liebowitz \& } \\
\text { Latman, P.C. }\end{array}$ & PC & $12 / 01 / 72$ & 50 & 1 & \\
\hline $\begin{array}{l}\text { Cravath Swaine \& } \\
\text { Moore LLP }\end{array}$ & LLP & $03 / 25 / 03$ & 499 & 3 & 5.6 \\
\hline $\begin{array}{l}\text { Curtis Mallet-Prevost } \\
\text { Colt \& Mosle LLP } \\
\end{array}$ & LLP & $07 / 28 / 99$ & 156 & 12 & 3.4 \\
\hline D'Amato \& Lynch & GP & & 84 & 2 & 0.6 \\
\hline $\begin{array}{l}\text { Darby \& Darby Profes- } \\
\text { sional Corporation }\end{array}$ & $\mathrm{PC}$ & $12 / 27 / 73$ & 73 & 2 & \\
\hline $\begin{array}{l}\text { Davidoff, Malito and } \\
\text { Hutcher, LLP }\end{array}$ & LLP & $12 / 22 / 94$ & 42 & 4 & 5.6 \\
\hline \begin{tabular}{|l|} 
Davidson, Davidson \& \\
Kappel, LLC \\
\end{tabular} & LLC & $04 / 01 / 98$ & 26 & 1 & \\
\hline Davis \& Gilbert, LLP & LLP & $03 / 10 / 98$ & 84 & 1 & 9.0 \\
\hline Davis Polk \& Wardwell & GP & & 624 & 9 & 5.6 \\
\hline $\begin{array}{l}\text { Debevoise \& Plimpton } \\
\text { LLP }\end{array}$ & LLP & $12 / 30 / 03$ & 514 & 8 & 6.3 \\
\hline Dewey Ballantine LLP & LLP & $09 / 26 / 97$ & 550 & 13 & 5.5 \\
\hline
\end{tabular}


APPENDIX A-Continued

\begin{tabular}{|c|c|c|c|c|c|}
\hline Dreier LLP & LLP & $10 / 17 / 97$ & 28 & 1 & 75.5 \\
\hline $\begin{array}{l}\text { Eaton \& Van Winkle } \\
\text { LLP }\end{array}$ & LLP & $09 / 04 / 02$ & 27 & 2 & 6.1 \\
\hline \begin{tabular}{|l|} 
Emmet Marvin \& Mar- \\
tin LLP \\
\end{tabular} & LLP & $12 / 30 / 94$ & 62 & 3 & 1.5 \\
\hline $\begin{array}{l}\text { Epstein Becker \& Green } \\
\text { PC } \\
\end{array}$ & $\mathrm{PC}$ & $06 / 23 / 80$ & 355 & 12 & \\
\hline $\begin{array}{l}\text { Esanu Katsky Korins \& } \\
\text { Siger, LLP }\end{array}$ & LLP & $07 / 18 / 97$ & 33 & 1 & 4.5 \\
\hline $\begin{array}{l}\text { Fischbein Badillo Wag- } \\
\text { ner Harding }\end{array}$ & GP & & 79 & 3 & 3.9 \\
\hline Fish \& Neave & GP & & 173 & 3 & 4.4 \\
\hline $\begin{array}{l}\text { Fitzpatrick Cella Harper } \\
\& \text { Scinto }\end{array}$ & GP & & 142 & 3 & 7.1 \\
\hline \begin{tabular}{|l|} 
Flemming, Zulack \& \\
Williamson, LLP \\
\end{tabular} & LLP & $11 / 23 / 94$ & 28 & 2 & 2.4 \\
\hline $\begin{array}{l}\text { Ford Marrin Esposito } \\
\text { Witmeyer \& Gleser, } \\
\text { L.L.P. }\end{array}$ & LLP & $03 / 02 / 95$ & 27 & 2 & 2.2 \\
\hline $\begin{array}{l}\text { Fragomen, Del Rey, } \\
\text { Bernsen \& Loewy, LLP }\end{array}$ & LLP & $06 / 29 / 04$ & 141 & 17 & 19.7 \\
\hline $\begin{array}{l}\text { Frankfurt Kurnit Klein } \\
\& \text { Selz, PC }\end{array}$ & $\mathrm{PC}$ & $09 / 24 / 80$ & 41 & 1 & \\
\hline \begin{tabular}{|l|} 
Fried Frank Harris \\
Shriver \& Jacobson LLP \\
\end{tabular} & LLP & $12 / 23 / 03$ & 550 & 5 & 4.0 \\
\hline $\begin{array}{l}\text { Friedman Kaplan Seiler } \\
\text { \& Adelman LLP }\end{array}$ & LLP & $04 / 13 / 95$ & 47 & 2 & 11.1 \\
\hline $\begin{array}{l}\text { Frommer Lawrence \& } \\
\text { Haug LLP } \\
\end{array}$ & LLP & $09 / 02 / 97$ & 52 & 2 & 19.3 \\
\hline $\begin{array}{l}\text { Fross Zelnick Lehrman } \\
\text { \& Zissu, P.C. } \\
\end{array}$ & $\mathrm{PC}$ & $04 / 02 / 82$ & 49 & 1 & \\
\hline $\begin{array}{l}\text { Gianni Origoni Grippo } \\
\text { \& Partners }\end{array}$ & GP & & 270 & 7 & 9.4 \\
\hline \begin{tabular}{|l|} 
Gibney, Anthony \& \\
Flaherty, LLP \\
\end{tabular} & LLP & $11 / 30 / 94$ & 34 & 4 & -1.5 \\
\hline $\begin{array}{l}\text { Goldberg Weprin \& } \\
\text { Ustin LLP } \\
\end{array}$ & LLP & $11 / 21 / 96$ & 27 & 1 & 7.3 \\
\hline Goldfarb \& Fleece & GP & & 26 & 1 & 4.9 \\
\hline $\begin{array}{l}\text { Golenbock Eiseman } \\
\text { Assor Bell \& Peskoe } \\
\text { LLP }\end{array}$ & LLP & $08 / 29 / 03$ & 35 & 1 & 9.5 \\
\hline $\begin{array}{l}\text { Goodkind Labaton } \\
\text { Rudoff \& Sucharow } \\
\text { LLP }\end{array}$ & LLP & $10 / 26 / 94$ & 46 & 2 & 3.5 \\
\hline Gordon \& Silber, P.C. & $\mathrm{PC}$ & $07 / 03 / 79$ & 29 & 2 & \\
\hline Graubard Miller & GP & & 28 & 1 & -3.4 \\
\hline $\begin{array}{l}\text { Grubman Indursky } \\
\text { Schindler \& Goldstein, } \\
\text { P.C. }\end{array}$ & $\mathrm{PC}$ & $10 / 01 / 74$ & 30 & 1 & \\
\hline $\begin{array}{l}\text { Grunfeld, Desiderio, } \\
\text { Lebowitz, Silverman \& } \\
\text { Klestadt LLP }\end{array}$ & LLP & $03 / 16 / 95$ & 32 & 4 & 4.1 \\
\hline Hahn \& Hessen LLP & LLP & $05 / 23 / 95$ & 48 & 2 & -0.6 \\
\hline $\begin{array}{l}\text { Hawkins Delafield \& } \\
\text { Wood LLP }\end{array}$ & LLP & $12 / 18 / 03$ & 111 & 7 & 1.1 \\
\hline Healy \& Baillie, LLP & LLP & $08 / 22 / 96$ & 27 & 3 & 4.3 \\
\hline $\begin{array}{l}\text { Heidell Pittoni Murphy } \\
\text { \& Bach LLP } \\
\end{array}$ & LLP & $12 / 15 / 98$ & 64 & 2 & 4.1 \\
\hline Herrick Feinstein LLP & LLP & $12 / 27 / 94$ & 124 & 3 & 13.7 \\
\hline Herzfeld \& Rubin PC & $\mathrm{PC}$ & $09 / 29 / 71$ & 100 & 6 & \\
\hline \begin{tabular}{|l|} 
Hughes Hubbard \& \\
Reed LLP \\
\end{tabular} & LLP & $05 / 14 / 96$ & 303 & 7 & 2.9 \\
\hline $\begin{array}{l}\text { Jacobowitz, Garfinkel \& } \\
\text { Lesman }\end{array}$ & GP & & 32 & 1 & 9.3 \\
\hline
\end{tabular}




\section{APPENDIX A-Continued}

\begin{tabular}{|c|c|c|c|c|c|}
\hline $\begin{array}{l}\text { Jones Hirsch Connors \& } \\
\text { Bull P.C. }\end{array}$ & $\mathrm{PC}$ & $01 / 29 / 97$ & 50 & 5 & \\
\hline Kane Kessler, P.C. & $\mathrm{PC}$ & $02 / 01 / 71$ & 32 & 2 & \\
\hline $\begin{array}{l}\text { Kasowitz Benson Torres } \\
\text { \& Friedman LLP }\end{array}$ & LLP & $03 / 14 / 95$ & 150 & 5 & 17.0 \\
\hline $\begin{array}{l}\text { Kaufman Borgeest \& } \\
\text { Ryan LLP } \\
\end{array}$ & LLP & $03 / 14 / 03$ & 67 & 5 & 29.2 \\
\hline Kaye Scholer LLP & LLP & $12 / 29 / 95$ & 400 & 9 & 4.1 \\
\hline $\begin{array}{l}\text { Kelley Drye \& Warren } \\
\text { LLP }\end{array}$ & LLP & $05 / 09 / 96$ & 305 & 8 & 0.2 \\
\hline Kenyon \& Kenyon & GP & & 198 & 3 & 11.4 \\
\hline $\begin{array}{l}\text { Kleinberg, Kaplan, } \\
\text { Wolff \& Cohen, P.C. } \\
\end{array}$ & $\mathrm{PC}$ & $10 / 27 / 75$ & 26 & 2 & \\
\hline $\begin{array}{l}\text { Kopff, Nardelli \& Dopf } \\
\text { LLP }\end{array}$ & LLP & $07 / 24 / 96$ & 28 & 1 & -3.1 \\
\hline $\begin{array}{l}\text { Kramer Levin Naftalis } \\
\text { \& Frankel LLP } \\
\end{array}$ & LLP & $10 / 23 / 98$ & 260 & 2 & 9.0 \\
\hline $\begin{array}{l}\text { Kronish Lieb Weiner \& } \\
\text { Hellman LLP } \\
\end{array}$ & LLP & $03 / 01 / 95$ & 101 & 1 & 4.8 \\
\hline $\begin{array}{l}\text { Kurzman Eisenberg } \\
\text { Corbin Lever \& Good- } \\
\text { man, LLP }\end{array}$ & LLP & $02 / 14 / 95$ & 27 & 2 & 13.6 \\
\hline Ladas \& Parry & LLP & $11 / 21 / 03$ & 50 & 5 & 1.3 \\
\hline $\begin{array}{l}\text { Landman Corsi Ballaine } \\
\text { \& Ford P.C. } \\
\end{array}$ & $\mathrm{PC}$ & $09 / 18 / 95$ & 46 & 3 & \\
\hline $\begin{array}{l}\text { LeBoeuf Lamb Greene } \\
\text { \& Macrae LLP } \\
\end{array}$ & LLP & $10 / 24 / 94$ & 650 & 22 & 1.7 \\
\hline $\begin{array}{l}\text { Lester Schwab Katz \& } \\
\text { Dwyer LLP }\end{array}$ & LLP & $06 / 16 / 99$ & 65 & 2 & -3.7 \\
\hline London Fischer LLP & LLP & $05 / 11 / 99$ & 50 & 2 & 30.1 \\
\hline $\begin{array}{l}\text { Martin Clearwater \& } \\
\text { Bell LLP } \\
\end{array}$ & LLP & $10 / 17 / 02$ & 70 & 3 & 4.3 \\
\hline $\begin{array}{l}\text { McAloon \& Friedman, } \\
\text { P.C. }\end{array}$ & $\mathrm{PC}$ & $10 / 07 / 77$ & 37 & 1 & \\
\hline $\begin{array}{l}\text { McLaughlin \& Stern, } \\
\text { LLP }\end{array}$ & LLP & $11 / 15 / 94$ & 47 & 2 & 10.0 \\
\hline Mendes \& Mount LLP & LLP & $12 / 11 / 95$ & 160 & 3 & 0.1 \\
\hline $\begin{array}{l}\text { Milbank Tweed Hadley } \\
\& \text { McCloy LLP } \\
\end{array}$ & LLP & $02 / 01 / 99$ & 496 & 9 & 4.4 \\
\hline $\begin{array}{l}\text { Morgan \& Finnegan } \\
\text { LLP }\end{array}$ & LLP & $12 / 19 / 94$ & 98 & 2 & 1.6 \\
\hline $\begin{array}{l}\text { Morris Duffy Alonso \& } \\
\text { Faley }\end{array}$ & LLP & $09 / 06 / 95$ & 80 & 1 & \\
\hline $\begin{array}{l}\text { Morrison Cohen Singer } \\
\text { \& Weinstein LLP }\end{array}$ & LLP & $12 / 23 / 94$ & 83 & 1 & 7.7 \\
\hline $\begin{array}{l}\text { Morvillo, Abramowitz, } \\
\text { Grand, Iason \& Silber- } \\
\text { berg, P.C. }\end{array}$ & $\mathrm{PC}$ & $09 / 06 / 79$ & 38 & 1 & \\
\hline Moses \& Singer LLP & LLP & $05 / 24 / 95$ & 65 & 2 & 3.8 \\
\hline $\begin{array}{l}\text { Mound Cotton Wollan } \\
\& \text { Greengrass }\end{array}$ & GP & & 73 & 5 & 3.2 \\
\hline $\begin{array}{l}\text { Newman Fitch Altheim } \\
\text { Myers, P.C. }\end{array}$ & $\mathrm{PC}$ & $06 / 25 / 75$ & 41 & 2 & \\
\hline $\begin{array}{l}\text { Nicoletti Hornig Camp- } \\
\text { ise Sweeney \& Paige }\end{array}$ & GP & & 28 & 2 & 28.9 \\
\hline $\begin{array}{l}\text { Ohrenstein \& Brown } \\
\text { LLP }\end{array}$ & LLP & $04 / 27 / 95$ & 56 & 3 & 8.7 \\
\hline $\begin{array}{l}\text { Olshan Grundman } \\
\text { Frome Rosenzweig \& } \\
\text { Wolosky LLP }\end{array}$ & LLP & $07 / 10 / 95$ & 54 & 2 & 6.8 \\
\hline $\begin{array}{l}\text { Ostrolenk, Faber, Gerb } \\
\& \text { Soffen, LLP }\end{array}$ & LLP & $06 / 08 / 95$ & 28 & 2 & 1.4 \\
\hline $\begin{array}{l}\text { Otterbourg Steindler } \\
\text { Houston \& Rosen PC }\end{array}$ & $\mathrm{PC}$ & $06 / 09 / 70$ & 58 & 1 & \\
\hline \multicolumn{6}{|c|}{ (Continued on next page) } \\
\hline
\end{tabular}




\section{APPENDIX A-Continued}

\begin{tabular}{|c|c|c|c|c|c|}
\hline $\begin{array}{l}\text { Patterson, Belknap, } \\
\text { Webb \& Tyler LLP }\end{array}$ & LLP & $12 / 30 / 94$ & 181 & 1 & 4.2 \\
\hline $\begin{array}{l}\text { Paul Weiss Rifkind } \\
\text { Wharton \& Garrison } \\
\text { LLP }\end{array}$ & LLP & $12 / 23 / 02$ & 500 & 7 & 4.4 \\
\hline Pavia \& Harcourt LLP & LLP & $07 / 30 / 01$ & 34 & 1 & -4.4 \\
\hline Phillips Nizer LLP & LLP & $05 / 11 / 95$ & 78 & 3 & -2.7 \\
\hline Proskauer Rose LLP & LLP & $01 / 26 / 95$ & 600 & 7 & 4.1 \\
\hline $\begin{array}{l}\text { Pryor Cashman } \\
\text { Sherman \& Flynn LLP }\end{array}$ & LLP & $03 / 27 / 98$ & 125 & 1 & 4.3 \\
\hline $\begin{array}{l}\text { Putney, Twombly, Hall } \\
\& \text { Hirson LLP }\end{array}$ & LLP & $12 / 04 / 98$ & 29 & 4 & 2.8 \\
\hline Quirk and Bakalor, P.C. & $\mathrm{PC}$ & $09 / 14 / 71$ & 29 & 2 & \\
\hline $\begin{array}{l}\text { Richards Spears Kibbe } \\
\text { \& Orbe LLP }\end{array}$ & LLP & $12 / 31 / 02$ & 55 & 2 & 14.4 \\
\hline Roberts \& Holland LLP & LLP & $11 / 09 / 94$ & 40 & 2 & -0.4 \\
\hline $\begin{array}{l}\text { Robinson Brog Lein- } \\
\text { wand Greene Genovese } \\
\text { \& Gluck P.C. }\end{array}$ & $\mathrm{PC}$ & $02 / 14 / 72$ & 50 & 1 & \\
\hline Rosenberg \& Estis, P.C. & $\mathrm{PC}$ & $06 / 02 / 76$ & 36 & 1 & \\
\hline $\begin{array}{l}\text { Sabin, Bermant \& } \\
\text { Gould LLP }\end{array}$ & LLP & $12 / 20 / 95$ & 36 & 1 & 5.4 \\
\hline Salans & GP & & 400 & 14 & 21.2 \\
\hline \begin{tabular}{|l|} 
Satterlee Stephens \\
Burke \& Burke LLP \\
\end{tabular} & LLP & $12 / 30 / 94$ & 58 & 2 & -0.5 \\
\hline $\begin{array}{l}\text { Schulte Roth \& Zabel } \\
\text { LLP }\end{array}$ & LLP & $08 / 23 / 96$ & 300 & 2 & 7.2 \\
\hline Seward \& Kissel LLP & LLP & $01 / 26 / 99$ & 115 & 2 & 3.6 \\
\hline $\begin{array}{l}\text { Shearman \& Sterling } \\
\text { LLP }\end{array}$ & LLP & $06 / 16 / 03$ & 697 & 18 & 7.7 \\
\hline $\begin{array}{l}\text { Simpson Thacher \& } \\
\text { Bartlett LLP } \\
\end{array}$ & LLP & $05 / 23 / 03$ & 602 & 6 & 6.7 \\
\hline \begin{tabular}{|l} 
Skadden Arps Slate \\
Meagher \& Flom LLP
\end{tabular} & LLP & $05 / 25 / 01$ & 1750 & 21 & 5.9 \\
\hline $\begin{array}{l}\text { Smith Mazure Director } \\
\text { Wilkins Young Yager- } \\
\text { man \& Tarallo, P.C. }\end{array}$ & $\mathrm{PC}$ & $12 / 09 / 88$ & 32 & 1 & \\
\hline $\begin{array}{l}\text { Snow Becker Krauss } \\
\text { P.C. }\end{array}$ & $\mathrm{PC}$ & $02 / 21 / 80$ & 26 & 1 & \\
\hline $\begin{array}{l}\text { Sokolow, Dunaud, Mer- } \\
\text { cadier \& Carreras LLP }\end{array}$ & LLP & $02 / 03 / 98$ & 38 & 4 & 44.3 \\
\hline \begin{tabular}{|l|} 
Stroock \& Stroock \& \\
Lavan LLP \\
\end{tabular} & LLP & $01 / 24 / 97$ & 345 & 3 & 0.2 \\
\hline $\begin{array}{l}\text { Sullivan \& Cromwell } \\
\text { LLP }\end{array}$ & LLP & $12 / 20 / 02$ & 661 & 12 & 10.6 \\
\hline $\begin{array}{l}\text { Sullivan Papain Block } \\
\text { McGrath \& Cannavo } \\
\text { P.C. }\end{array}$ & $\mathrm{PC}$ & $09 / 23 / 74$ & 35 & 3 & \\
\hline $\begin{array}{l}\text { Tannenbaum Helpern } \\
\text { Syracuse \& Hirschtritt } \\
\text { LLP }\end{array}$ & LLP & $06 / 13 / 95$ & 46 & 2 & 9.1 \\
\hline \begin{tabular}{|l|} 
Thacher Proffitt \& \\
Wood LLP \\
\end{tabular} & LLP & $09 / 02 / 03$ & 191 & 5 & 6.7 \\
\hline $\begin{array}{l}\text { Thelen Reid \& Priest } \\
\text { LLP }\end{array}$ & LLP & $11 / 19 / 96$ & 408 & 6 & 4.3 \\
\hline Torys, LLP & LLP & $11 / 30 / 01$ & 280 & 2 & 4.0 \\
\hline Wachtel \& Masyr, LLP & LLP & $12 / 13 / 94$ & 34 & 1 & 1.0 \\
\hline $\begin{array}{l}\text { Wachtell Lipton Rosen } \\
\text { \& Katz }\end{array}$ & GP & & 181 & 1 & 7.0 \\
\hline $\begin{array}{l}\text { Warshaw Burstein } \\
\text { Cohen Schlesinger \& } \\
\text { Kuh, LLP }\end{array}$ & LLP & $03 / 02 / 95$ & 34 & 1 & -0.3 \\
\hline $\begin{array}{l}\text { Watson Farley \& Wil- } \\
\text { liams }\end{array}$ & GP & & 220 & 7 & -1.8 \\
\hline
\end{tabular}




\section{APPENDIX A-Continued}

\begin{tabular}{|l|l|l|l|l|l|}
\hline $\begin{array}{l}\text { Weil Gotshal \& Manges } \\
\text { LLP }\end{array}$ & LLP & $12 / 18 / 95$ & 1000 & 17 & 5.5 \\
\hline Weitz \& Luxenberg, PC & PC & $02 / 01 / 91$ & 45 & 4 & \\
\hline White \& Case LLP & LLP & $12 / 29 / 97$ & 1700 & 37 & 8.1 \\
\hline $\begin{array}{l}\text { White, Fleischner \& } \\
\text { Fino }\end{array}$ & LLP & $11 / 09 / 00$ & 30 & 3 & 2.7 \\
\hline $\begin{array}{l}\text { Willkie Farr \& Galla- } \\
\text { gher LLP }\end{array}$ & LLP & $08 / 29 / 03$ & 507 & 8 & 4.5 \\
\hline $\begin{array}{l}\text { Wilson, Elser, Mosko- } \\
\text { witz, Edelman \& Dicker } \\
\text { LLP }\end{array}$ & LLP & $02 / 26 / 98$ & 225 & 19 & 3.8 \\
\hline $\begin{array}{l}\text { Windels Marx Lane \& } \\
\text { Mittendorf LLP }\end{array}$ & LLP & $12 / 22 / 99$ & 100 & 5 & 9.1 \\
\hline $\begin{array}{l}\text { Wolf Haldenstein Adler } \\
\text { Freeman \& Herz LLP }\end{array}$ & LLP & $11 / 16 / 94$ & 55 & 5 & 3.7 \\
\hline $\begin{array}{l}\text { Wollmuth Maher \& } \\
\text { Deutsch LLP }\end{array}$ & LLP & $03 / 31 / 98$ & 26 & 2 & 40.1 \\
\hline $\begin{array}{l}\text { Wormser, Kiely, Galef } \\
\text { \& Jacobs LLP }\end{array}$ & LLP & $02 / 05 / 97$ & 36 & 2 & -0.1 \\
\hline $\begin{array}{l}\text { Zeichner Ellman \& } \\
\text { Krause LLP }\end{array}$ & LLP & $04 / 26 / 99$ & 27 & 3 & -0.6 \\
\hline
\end{tabular}

\section{APPENDIX B}

\begin{tabular}{|c|c|c|c|}
\hline FIRM & SALARY & TIER & COLLEGIAL \\
\hline Amster, Rothstein, \& Ebenstein & 120,000 & no & $\mathrm{N}$ \\
\hline Anderson Kill \& Olick, PC & 115,000 & yes & $\mathrm{C}$ \\
\hline Brown Raysman Millstein Felder \& Steiner LLP & 125,000 & yes & $\mathrm{N}$ \\
\hline Cadwalader Wickersham \& Taft LLP & 125,000 & no & $\mathrm{C}$ \\
\hline Cahill Gordon \& Reindel LLP & 125,000 & no & $\mathrm{N}$ \\
\hline Carter Ledyard \& Milburn LLP & 120,000 & no & $\mathrm{C}$ \\
\hline Chadbourne \& Parke LLP & 125,000 & no & $\mathrm{N}$ \\
\hline Cleary Gottlieb Steen \& Hamilton & 125,000 & no & $\mathrm{C}$ \\
\hline Clifford Chance US LLP & 125,000 & yes & $\mathrm{C}$ \\
\hline Cooper \& Dunham LLP & 115,000 & yes & $\mathrm{N}$ \\
\hline Coudert Brothers LLP & 125,000 & yes & $\mathrm{N}$ \\
\hline Cravath Swaine \& Moore LLP & 125,000 & no & $\mathrm{N}$ \\
\hline Curtis Mallet-Prevost Colt \& Mosle LLP & 125,000 & yes & $\mathrm{N}$ \\
\hline Darby \& Darby Professional Corporation & 125,000 & no & $\mathrm{N}$ \\
\hline Davis Polk \& Wardwell & 125,000 & no & $\mathrm{C}$ \\
\hline Debevoise \& Plimpton LLP & 125,000 & no & $\mathrm{C}$ \\
\hline Dewey Ballantine LLP & 125,000 & no & $\mathrm{C}$ \\
\hline Epstein Becker \& Green PC & & & $\mathrm{N}$ \\
\hline Fish \& Neave & 125,000 & no & $\mathrm{N}$ \\
\hline Fitzpatrick Cella Harper \& Scinto & 125,000 & no & $\mathrm{N}$ \\
\hline Fragomen, Del Rey, Bernsen \& Loewy, LLP & 95,000 & yes & $\mathrm{C}$ \\
\hline Fried Frank Harris Shriver \& Jacobson LLP & 125,000 & no & $\mathrm{C}$ \\
\hline Friedman Kaplan Seiler \& Adelman LLP & 125,000 & no & $\mathrm{C}$ \\
\hline Frommer Lawrence \& Haug LLP & 130,000 & no & $\mathrm{N}$ \\
\hline Hahn \& Hessen LLP & 110,000 & no & $\mathrm{C}$ \\
\hline Hawkins Delafield \& Wood LLP & 100,000 & yes & $\mathrm{C}$ \\
\hline Herrick Feinstein LLP & 130,000 & yes & $\mathrm{N}$ \\
\hline Hughes Hubbard \& Reed LLP & 125,000 & no & $\mathrm{N}$ \\
\hline Kasowitz Benson Torres \& Friedman LLP & & no & $\mathrm{C}$ \\
\hline Kaye Scholer LLP & 125,000 & no & $\mathrm{N}$ \\
\hline Kelley Drye \& Warren LLP & 125,000 & no & $\mathrm{C}$ \\
\hline Kenyon \& Kenyon & 125,000 & yes & $\mathrm{N}$ \\
\hline Kramer Levin Naftalis \& Frankel LLP & 125,000 & no & $\mathrm{C}$ \\
\hline Kronish Lieb Weiner \& Hellman LLP & 125,000 & no & $\mathrm{C}$ \\
\hline LeBoeuf Lamb Greene \& Macrae LLP & 125,000 & no & $\mathrm{N}$ \\
\hline Milbank Tweed Hadley \& McCloy LLP & 125,000 & & $\mathrm{~N}$ \\
\hline Morgan \& Finnegan LLP & 125,000 & no & $\mathrm{N}$ \\
\hline
\end{tabular}




\section{APPENDIX B-Continued}

\begin{tabular}{|c|c|c|c|}
\hline Morrison Cohen Singer \& Weinstein LLP & & & $\mathrm{N}$ \\
\hline Moses \& Singer LLP & 92,000 & no & \\
\hline $\begin{array}{l}\text { Olshan Grundman Frome Rosenzweig \& Wolosky } \\
\text { LLP }\end{array}$ & 115,000 & no & $\mathrm{C}$ \\
\hline Otterbourg Steindler Houston \& Rosen PC & 115,000 & no & $\mathrm{N}$ \\
\hline Patterson, Belknap, Webb \& Tyler LLP & 125,000 & no & $\mathrm{C}$ \\
\hline Paul Weiss Rifkind Wharton \& Garrison LLP & 125,000 & no & $\mathrm{N}$ \\
\hline Proskauer Rose LLP & 125,000 & no & $\mathrm{N}$ \\
\hline Pryor Cashman Sherman \& Flynn LLP & 110,000 & no & $\mathrm{N}$ \\
\hline Salans & 112,500 & yes & $\mathrm{N}$ \\
\hline Schulte Roth \& Zabel LLP & 125,000 & no & $\mathrm{N}$ \\
\hline Seward \& Kissel LLP & 140,000 & no & $\mathrm{N}$ \\
\hline Shearman \& Sterling LLP & 125,000 & no & $\mathrm{N}$ \\
\hline Simpson Thacher \& Bartlett LLP & 125,000 & no & $\mathrm{C}$ \\
\hline Skadden Arps Slate Meagher \& Flom LLP & 140,000 & no & $\mathrm{N}$ \\
\hline Stroock \& Stroock \& Lavan LLP & 125,000 & no & $\mathrm{N}$ \\
\hline Sullivan \& Cromwell LLP & 125,000 & no & $\mathrm{N}$ \\
\hline Thacher Proffitt \& Wood LLP & 125,000 & no & $\mathrm{C}$ \\
\hline Thelen Reid \& Priest LLP & 125,000 & yes & $\mathrm{C}$ \\
\hline Torys, LLP & 125,000 & no & $\mathrm{C}$ \\
\hline Wachtell Lipton Rosen \& Katz & 140,000 & no & $\mathrm{C}$ \\
\hline Weil Gotshal \& Manges LLP & 125,000 & no & $\mathrm{C}$ \\
\hline White \& Case LLP & 125,000 & yes & $\mathrm{N}$ \\
\hline Willkie Farr \& Gallagher LLP & 125,000 & no & $\mathrm{C}$ \\
\hline Windels Marx Lane \& Mittendorf LLP & & & $\mathrm{N}$ \\
\hline
\end{tabular}

\section{APPENDIX C}

\begin{tabular}{|c|c|c|c|}
\hline FIRM & FORTUNE & IN-HOUSE TOTAL & $\begin{array}{l}\text { IN-HOUSE } \\
\text { AVERAGE }\end{array}$ \\
\hline Amster, Rothstein, \& Ebenstein & 1 & 34 & 34 \\
\hline Anderson Kill \& Olick, PC & 1 & 120 & 120 \\
\hline $\begin{array}{l}\text { Brown Raysman Millstein Felder \& Steiner } \\
\text { LLP }\end{array}$ & 1 & 50 & 50 \\
\hline Cadwalader Wickersham \& Taft LLP & 5 & 745 & 149 \\
\hline Cahill Gordon \& Reindel LLP & 2 & 396 & 198 \\
\hline Chadbourne \& Parke LLP & 1 & 76 & 76 \\
\hline Cleary Gottlieb Steen \& Hamilton & 6 & 1512 & 252 \\
\hline Clifford Chance US LLP & 9 & 1884 & 209.3333333 \\
\hline Cowan, Liebowitz \& Latman, P.C. & 3 & 457 & 152.3333333 \\
\hline Cravath Swaine \& Moore LLP & 9 & 1886 & 209.5555556 \\
\hline Davis \& Gilbert, LLP & 1 & 27 & 27 \\
\hline Davis Polk \& Wardwell & 16 & 1677 & 104.8125 \\
\hline Debevoise \& Plimpton LLP & 7 & 843 & 120.4285714 \\
\hline Dewey Ballantine LLP & 2 & 208 & 104 \\
\hline Epstein Becker \& Green PC & 5 & 713 & 142.6 \\
\hline Fish \& Neave & 6 & 1383 & 230.5 \\
\hline Fitzpatrick Cella Harper \& Scinto & 3 & 337 & 112.3333333 \\
\hline $\begin{array}{l}\text { Fragomen, Del Rey, Bernsen \& Loewy, } \\
\text { LLP }\end{array}$ & 1 & 154 & 154 \\
\hline Fried Frank Harris Shriver \& Jacobson LLP & 6 & 761 & 126.8333333 \\
\hline Friedman Kaplan Seiler \& Adelman LLP & 1 & 73 & 73 \\
\hline Hughes Hubbard \& Reed LLP & 3 & 357 & 119 \\
\hline Kasowitz Benson Torres \& Friedman LLP & 1 & 11 & 11 \\
\hline Kaye Scholer LLP & 3 & 417 & 139 \\
\hline Kelley Drye \& Warren LLP & 1 & 89 & 89 \\
\hline Kenyon \& Kenyon & 1 & 246 & 246 \\
\hline Kramer Levin Naftalis \& Frankel LLP & 2 & 1050 & 525 \\
\hline Ladas \& Parry & 6 & 1598 & 266.3333333 \\
\hline LeBoeuf Lamb Greene \& Macrae LLP & 7 & 1616 & 230.8571429 \\
\hline Milbank Tweed Hadley \& McCloy LLP & 2 & 1050 & 525 \\
\hline Morgan \& Finnegan LLP & 1 & 174 & 174 \\
\hline
\end{tabular}




\section{APPENDIX C-Continued}

\begin{tabular}{|l|c|c|c|}
\hline Morrison Cohen Singer \& Weinstein LLP & 1 & 17 & 17 \\
\hline Patterson, Belknap, Webb \& Tyler LLP & 2 & 320 & 160 \\
\hline Paul Weiss Rifkind Wharton \& Garrison LLP & 7 & 2143 & 306.1428571 \\
\hline Proskauer Rose LLP & 7 & 2084 & 297.7142857 \\
\hline Shearman \& Sterling LLP & 6 & 2632 & 438.6666667 \\
\hline Simpson Thacher \& Bartlett LLP & 14 & 2047 & 146.2142857 \\
\hline Skadden Arps Slate Meagher \& Flom LLP & 32 & 4337 & 135.53125 \\
\hline Stroock \& Stroock \& Lavan LLP & 4 & 331 & 82.75 \\
\hline Sullivan \& Cromwell LLP & 7 & 1606 & 229.4285714 \\
\hline Thelen Reid \& Priest LLP & 6 & 172 & 28.66666667 \\
\hline Wachtell Lipton Rosen \& Katz & 13 & 1562 & 120.1538462 \\
\hline Weil Gotshal \& Manges LLP & 7 & 2380 & 340 \\
\hline White \& Case LLP & 3 & 335 & 111.6666667 \\
\hline
\end{tabular}

\section{APPENDIX D}

\begin{tabular}{|c|c|c|}
\hline FIRM & YEAR & PROFITS \\
\hline Brown Raysman Millstein Felder \& Steiner LLP & 1993 & \\
\hline Brown Raysman Millstein Felder \& Steiner LLP & 1994 & \\
\hline Brown Raysman Millstein Felder \& Steiner LLP & 1995 & \\
\hline Brown Raysman Millstein Felder \& Steiner LLP & 1996 & \\
\hline Brown Raysman Millstein Felder \& Steiner LLP & 1997 & \\
\hline Brown Raysman Millstein Felder \& Steiner LLP & 1998 & \\
\hline Brown Raysman Millstein Felder \& Steiner LLP & 1999 & \\
\hline Brown Raysman Millstein Felder \& Steiner LLP & 2000 & \\
\hline Brown Raysman Millstein Felder \& Steiner LLP & 2001 & \\
\hline Brown Raysman Millstein Felder \& Steiner LLP & 2002 & 530000 \\
\hline Brown Raysman Millstein Felder \& Steiner LLP & 2003 & 565000 \\
\hline Cadwalader Wickersham \& Taft LLP & 1993 & 505000 \\
\hline Cadwalader Wickersham \& Taft LLP & 1994 & 425000 \\
\hline Cadwalader Wickersham \& Taft LLP & 1995 & 565000 \\
\hline Cadwalader Wickersham \& Taft LLP & 1996 & 645000 \\
\hline Cadwalader Wickersham \& Taft LLP & 1997 & 785000 \\
\hline Cadwalader Wickersham \& Taft LLP & 1998 & 820000 \\
\hline Cadwalader Wickersham \& Taft LLP & 1999 & 935000 \\
\hline Cadwalader Wickersham \& Taft LLP & 2000 & 1040000 \\
\hline Cadwalader Wickersham \& Taft LLP & 2001 & 1105000 \\
\hline Cadwalader Wickersham \& Taft LLP & 2002 & 1250000 \\
\hline Cadwalader Wickersham \& Taft LLP & 2003 & 1610000 \\
\hline Cahill Gordon \& Reindel LLP & 1993 & 1210000 \\
\hline Cahill Gordon \& Reindel LLP & 1994 & 1200000 \\
\hline Cahill Gordon \& Reindel LLP & 1995 & 1250000 \\
\hline Cahill Gordon \& Reindel LLP & 1996 & 1400000 \\
\hline Cahill Gordon \& Reindel LLP & 1997 & 1445000 \\
\hline Cahill Gordon \& Reindel LLP & 1998 & 1600000 \\
\hline Cahill Gordon \& Reindel LLP & 1999 & 1710000 \\
\hline Cahill Gordon \& Reindel LLP & 2000 & 1610000 \\
\hline Cahill Gordon \& Reindel LLP & 2001 & 1805000 \\
\hline Cahill Gordon \& Reindel LLP & 2002 & 1845000 \\
\hline Cahill Gordon \& Reindel LLP & 2003 & 2405000 \\
\hline Chadbourne \& Parke LLP & 1993 & 525000 \\
\hline Chadbourne \& Parke LLP & 1994 & 515000 \\
\hline Chadbourne \& Parke LLP & 1995 & 545000 \\
\hline Chadbourne \& Parke LLP & 1996 & 610000 \\
\hline Chadbourne \& Parke LLP & 1997 & 535000 \\
\hline Chadbourne \& Parke LLP & 1998 & 615000 \\
\hline Chadbourne \& Parke LLP & 1999 & 815000 \\
\hline Chadbourne \& Parke LLP & 2000 & 940000 \\
\hline Chadbourne \& Parke LLP & 2001 & 980000 \\
\hline Chadbourne \& Parke LLP & 2002 & 1000000 \\
\hline Chadbourne \& Parke LLP & 2003 & 1010000 \\
\hline
\end{tabular}




\section{APPENDIX D-Continued}

\begin{tabular}{|c|c|c|}
\hline Cleary Gottlieb Steen \& Hamilton & 1993 & 890000 \\
\hline Cleary Gottlieb Steen \& Hamilton & 1994 & 885000 \\
\hline Cleary Gottlieb Steen \& Hamilton & 1995 & 910000 \\
\hline Cleary Gottlieb Steen \& Hamilton & 1996 & 975000 \\
\hline Cleary Gottlieb Steen \& Hamilton & 1997 & 1060000 \\
\hline Cleary Gottlieb Steen \& Hamilton & 1998 & 1075000 \\
\hline Cleary Gottlieb Steen \& Hamilton & 1999 & 1225000 \\
\hline Cleary Gottlieb Steen \& Hamilton & 2000 & 1250000 \\
\hline Cleary Gottlieb Steen \& Hamilton & 2001 & 1325000 \\
\hline Cleary Gottlieb Steen \& Hamilton & 2002 & 1445000 \\
\hline Cleary Gottlieb Steen \& Hamilton & 2003 & 1445000 \\
\hline Coudert Brothers LLP & 1993 & 260000 \\
\hline Coudert Brothers LLP & 1994 & 370000 \\
\hline Coudert Brothers LLP & 1995 & 310000 \\
\hline Coudert Brothers LLP & 1996 & 315000 \\
\hline Coudert Brothers LLP & 1997 & 380000 \\
\hline Coudert Brothers LLP & 1998 & 395000 \\
\hline Coudert Brothers LLP & 1999 & 425000 \\
\hline Coudert Brothers LLP & 2000 & 390000 \\
\hline Coudert Brothers LLP & 2001 & 455000 \\
\hline Coudert Brothers LLP & 2002 & 475000 \\
\hline Coudert Brothers LLP & 2003 & 420000 \\
\hline Cravath Swaine \& Moore LLP & 1993 & 1410000 \\
\hline Cravath Swaine \& Moore LLP & 1994 & 1225000 \\
\hline Cravath Swaine \& Moore LLP & 1995 & 1340000 \\
\hline Cravath Swaine \& Moore LLP & 1996 & 1515000 \\
\hline Cravath Swaine \& Moore LLP & 1997 & 1790000 \\
\hline Cravath Swaine \& Moore LLP & 1998 & 2050000 \\
\hline Cravath Swaine \& Moore LLP & 1999 & 2110000 \\
\hline Cravath Swaine \& Moore LLP & 2000 & 2245000 \\
\hline Cravath Swaine \& Moore LLP & 2001 & 2135000 \\
\hline Cravath Swaine \& Moore LLP & 2002 & 1960000 \\
\hline Cravath Swaine \& Moore LLP & 2003 & 2080000 \\
\hline Curtis Mallet-Prevost Colt \& Mosle LLP & 1993 & \\
\hline Curtis Mallet-Prevost Colt \& Mosle LLP & 1994 & \\
\hline Curtis Mallet-Prevost Colt \& Mosle LLP & 1995 & \\
\hline Curtis Mallet-Prevost Colt \& Mosle LLP & 1996 & \\
\hline Curtis Mallet-Prevost Colt \& Mosle LLP & 1997 & \\
\hline Curtis Mallet-Prevost Colt \& Mosle LLP & 1998 & 615000 \\
\hline Curtis Mallet-Prevost Colt \& Mosle LLP & 1999 & 655000 \\
\hline Curtis Mallet-Prevost Colt \& Mosle LLP & 2000 & 700000 \\
\hline Curtis Mallet-Prevost Colt \& Mosle LLP & 2001 & \\
\hline Curtis Mallet-Prevost Colt \& Mosle LLP & 2002 & \\
\hline Curtis Mallet-Prevost Colt \& Mosle LLP & 2003 & \\
\hline Davis Polk \& Wardwell & 1993 & 1020000 \\
\hline Davis Polk \& Wardwell & 1994 & 940000 \\
\hline Davis Polk \& Wardwell & 1995 & 975000 \\
\hline \begin{tabular}{|l|} 
Davis Polk \& Wardwell \\
\end{tabular} & 1996 & 1125000 \\
\hline Davis Polk \& Wardwell & 1997 & 1295000 \\
\hline Davis Polk \& Wardwell & 1998 & 1530000 \\
\hline Davis Polk \& Wardwell & 1999 & 1610000 \\
\hline Davis Polk \& Wardwell & 2000 & 1740000 \\
\hline Davis Polk \& Wardwell & 2001 & 1775000 \\
\hline Davis Polk \& Wardwell & 2002 & 1775000 \\
\hline Davis Polk \& Wardwell & 2003 & 1925000 \\
\hline Debevoise \& Plimpton LLP & 1993 & 685000 \\
\hline Debevoise \& Plimpton LLP & 1994 & 805000 \\
\hline Debevoise \& Plimpton LLP & 1995 & 890000 \\
\hline Debevoise \& Plimpton LLP & 1996 & 1020000 \\
\hline Debevoise \& Plimpton LLP & 1997 & 1105000 \\
\hline Debevoise \& Plimpton LLP & 1998 & 1200000 \\
\hline Debevoise \& Plimpton LLP & 1999 & 1225000 \\
\hline
\end{tabular}




\section{APPENDIX D-Continued}

\begin{tabular}{|c|c|c|}
\hline Debevoise \& Plimpton LLP & 2000 & 1225000 \\
\hline Debevoise \& Plimpton LLP & 2001 & 1105000 \\
\hline Debevoise \& Plimpton LLP & 2002 & 1085000 \\
\hline Debevoise \& Plimpton LLP & 2003 & 1260000 \\
\hline Dewey Ballantine LLP & 1993 & 510000 \\
\hline Dewey Ballantine LLP & 1994 & 515000 \\
\hline Dewey Ballantine LLP & 1995 & 530000 \\
\hline Dewey Ballantine LLP & 1996 & 650000 \\
\hline Dewey Ballantine LLP & 1997 & 780000 \\
\hline Dewey Ballantine LLP & 1998 & 860000 \\
\hline Dewey Ballantine LLP & 1999 & 950000 \\
\hline Dewey Ballantine LLP & 2000 & 1035000 \\
\hline Dewey Ballantine LLP & 2001 & 1075000 \\
\hline Dewey Ballantine LLP & 2002 & 1125000 \\
\hline Dewey Ballantine LLP & 2003 & 1150000 \\
\hline Fish \& Neave & 1993 & \\
\hline Fish \& Neave & 1994 & \\
\hline Fish \& Neave & 1995 & \\
\hline Fish \& Neave & 1996 & \\
\hline Fish \& Neave & 1997 & \\
\hline Fish \& Neave & 1998 & 740000 \\
\hline Fish \& Neave & 1999 & 700000 \\
\hline Fish \& Neave & 2000 & 675000 \\
\hline Fish \& Neave & 2001 & 725000 \\
\hline Fish \& Neave & 2002 & 800000 \\
\hline Fish \& Neave & 2003 & 730000 \\
\hline Fried Frank Harris Shriver \& Jacobson LLP & 1993 & 400000 \\
\hline Fried Frank Harris Shriver \& Jacobson LLP & 1994 & 400000 \\
\hline Fried Frank Harris Shriver \& Jacobson LLP & 1995 & 495000 \\
\hline Fried Frank Harris Shriver \& Jacobson LLP & 1996 & 615000 \\
\hline Fried Frank Harris Shriver \& Jacobson LLP & 1997 & 580000 \\
\hline Fried Frank Harris Shriver \& Jacobson LLP & 1998 & 760000 \\
\hline Fried Frank Harris Shriver \& Jacobson LLP & 1999 & 855000 \\
\hline Fried Frank Harris Shriver \& Jacobson LLP & 2000 & 1045000 \\
\hline Fried Frank Harris Shriver \& Jacobson LLP & 2001 & 875000 \\
\hline Fried Frank Harris Shriver \& Jacobson LLP & 2002 & 930000 \\
\hline Fried Frank Harris Shriver \& Jacobson LLP & 2003 & 980000 \\
\hline Hughes Hubbard \& Reed LLP & 1993 & 300000 \\
\hline Hughes Hubbard \& Reed LLP & 1994 & 325000 \\
\hline Hughes Hubbard \& Reed LLP & 1995 & 335000 \\
\hline Hughes Hubbard \& Reed LLP & 1996 & 350000 \\
\hline Hughes Hubbard \& Reed LLP & 1997 & 400000 \\
\hline Hughes Hubbard \& Reed LLP & 1998 & 420000 \\
\hline Hughes Hubbard \& Reed LLP & 1999 & 450000 \\
\hline Hughes Hubbard \& Reed LLP & 2000 & 520000 \\
\hline Hughes Hubbard \& Reed LLP & 2001 & 640,000 \\
\hline Hughes Hubbard \& Reed LLP & 2002 & 820000 \\
\hline Hughes Hubbard \& Reed LLP & 2003 & 950000 \\
\hline Kaye Scholer LLP & 1993 & 535000 \\
\hline Kaye Scholer LLP & 1994 & 490000 \\
\hline Kaye Scholer LLP & 1995 & 475000 \\
\hline Kaye Scholer LLP & 1996 & 445000 \\
\hline Kaye Scholer LLP & 1997 & 525000 \\
\hline Kaye Scholer LLP & 1998 & 620000 \\
\hline Kaye Scholer LLP & 1999 & 690000 \\
\hline Kaye Scholer LLP & 2000 & 795000 \\
\hline Kaye Scholer LLP & 2001 & 890000 \\
\hline Kaye Scholer LLP & 2002 & 980000 \\
\hline Kaye Scholer LLP & 2003 & 1070000 \\
\hline Kelley Drye \& Warren LLP & 1993 & 255000 \\
\hline Kelley Drye \& Warren LLP & 1994 & 200000 \\
\hline Kelley Drye \& Warren LLP & 1995 & 275000 \\
\hline
\end{tabular}




\section{APPENDIX D-Continued}

\begin{tabular}{|c|c|c|}
\hline Kelley Drye \& Warren LLP & 1996 & 400000 \\
\hline Kelley Drye \& Warren LLP & 1997 & 430000 \\
\hline Kelley Drye \& Warren LLP & 1998 & 515000 \\
\hline Kelley Drye \& Warren LLP & 1999 & 575000 \\
\hline Kelley Drye \& Warren LLP & 2000 & 840000 \\
\hline Kelley Drye \& Warren LLP & 2001 & 625000 \\
\hline Kelley Drye \& Warren LLP & 2002 & 810000 \\
\hline Kelley Drye \& Warren LLP & 2003 & 790000 \\
\hline Kenyon \& Kenyon & 1993 & \\
\hline Kenyon \& Kenyon & 1994 & \\
\hline Kenyon \& Kenyon & 1995 & \\
\hline Kenyon \& Kenyon & 1996 & \\
\hline Kenyon \& Kenyon & 1997 & \\
\hline Kenyon \& Kenyon & 1998 & 550000 \\
\hline Kenyon \& Kenyon & 1999 & 500000 \\
\hline Kenyon \& Kenyon & 2000 & 565000 \\
\hline Kenyon \& Kenyon & 2001 & 615,000 \\
\hline Kenyon \& Kenyon & 2002 & 770000 \\
\hline Kenyon \& Kenyon & 2003 & 685000 \\
\hline Kramer Levin Naftalis \& Frankel LLP & 1993 & \\
\hline Kramer Levin Naftalis \& Frankel LLP & 1994 & \\
\hline Kramer Levin Naftalis \& Frankel LLP & 1995 & \\
\hline Kramer Levin Naftalis \& Frankel LLP & 1996 & \\
\hline Kramer Levin Naftalis \& Frankel LLP & 1997 & \\
\hline Kramer Levin Naftalis \& Frankel LLP & 1998 & 685000 \\
\hline Kramer Levin Naftalis \& Frankel LLP & 1999 & 710000 \\
\hline Kramer Levin Naftalis \& Frankel LLP & 2000 & 750000 \\
\hline Kramer Levin Naftalis \& Frankel LLP & 2001 & 795000 \\
\hline Kramer Levin Naftalis \& Frankel LLP & 2002 & 935000 \\
\hline Kramer Levin Naftalis \& Frankel LLP & 2003 & 1040000 \\
\hline LeBoeuf Lamb Greene \& Mac Rae LLP & 1993 & 340000 \\
\hline LeBoeuf Lamb Greene \& Mac Rae LLP & 1994 & 365000 \\
\hline LeBoeuf Lamb Greene \& Mac Rae LLP & 1995 & 360000 \\
\hline LeBoeuf Lamb Greene \& Mac Rae LLP & 1996 & 400000 \\
\hline LeBoeuf Lamb Greene \& Mac Rae LLP & 1997 & 450000 \\
\hline LeBoeuf Lamb Greene \& Mac Rae LLP & 1998 & 550000 \\
\hline LeBoeuf Lamb Greene \& Mac Rae LLP & 1999 & 620000 \\
\hline LeBoeuf Lamb Greene \& Mac Rae LLP & 2000 & 645000 \\
\hline LeBoeuf Lamb Greene \& Mac Rae LLP & 2001 & 705000 \\
\hline LeBoeuf Lamb Greene \& Mac Rae LLP & 2002 & 855000 \\
\hline LeBoeuf Lamb Greene \& Mac Rae LLP & 2003 & 935000 \\
\hline Milbank Tweed Hadley \& McCloy LLP & 1993 & 540000 \\
\hline Milbank Tweed Hadley \& McCloy LLP & 1994 & 575000 \\
\hline Milbank Tweed Hadley \& McCloy LLP & 1995 & 590000 \\
\hline Milbank Tweed Hadley \& McCloy LLP & 1996 & 735000 \\
\hline Milbank Tweed Hadley \& McCloy LLP & 1997 & 860000 \\
\hline Milbank Tweed Hadley \& McCloy LLP & 1998 & 1105000 \\
\hline Milbank Tweed Hadley \& McCloy LLP & 1999 & 1275000 \\
\hline Milbank Tweed Hadley \& McCloy LLP & 2000 & 1450000 \\
\hline Milbank Tweed Hadley \& McCloy LLP & 2001 & 1600000 \\
\hline Milbank Tweed Hadley \& McCloy LLP & 2002 & 1785000 \\
\hline Milbank Tweed Hadley \& McCloy LLP & 2003 & 1820000 \\
\hline Patterson, Belknap, Webb \& Tyler LLP & 1993 & \\
\hline Patterson, Belknap, Webb \& Tyler LLP & 1994 & \\
\hline Patterson, Belknap, Webb \& Tyler LLP & 1995 & \\
\hline Patterson, Belknap, Webb \& Tyler LLP & 1996 & \\
\hline Patterson, Belknap, Webb \& Tyler LLP & 1997 & \\
\hline Patterson, Belknap, Webb \& Tyler LLP & 1998 & 470000 \\
\hline Patterson, Belknap, Webb \& Tyler LLP & 1999 & 550000 \\
\hline Patterson, Belknap, Webb \& Tyler LLP & 2000 & 620000 \\
\hline Patterson, Belknap, Webb \& Tyler LLP & 2001 & 600000 \\
\hline Patterson, Belknap, Webb \& Tyler LLP & 2002 & 730000 \\
\hline
\end{tabular}




\section{APPENDIX D-Continued}

Patterson, Belknap, Webb \& Tyler LLP Paul Weiss Rifkind Wharton \& Garrison LLP

Paul Weiss Rifkind Wharton \& Garrison LLP

Paul Weiss Rifkind Wharton \& Garrison LLP

Paul Weiss Rifkind Wharton \& Garrison LLP

Paul Weiss Rifkind Wharton \& Garrison LLP

Paul Weiss Rifkind Wharton \& Garrison LLP

Paul Weiss Rifkind Wharton \& Garrison LLP

Paul Weiss Rifkind Wharton \& Garrison LLP

Paul Weiss Rifkind Wharton \& Garrison LLP

Paul Weiss Rifkind Wharton \& Garrison LLP

Paul Weiss Rifkind Wharton \& Garrison LLP

Proskauer Rose LLP

Proskauer Rose LLP

Proskauer Rose LLP

Proskauer Rose LLP

Proskauer Rose LLP

Proskauer Rose LLP

Proskauer Rose LLP

Proskauer Rose LLP

Proskauer Rose LLP

Proskauer Rose LLP

Proskauer Rose LLP

Schulte Roth \& Zabel LLP

Schulte Roth \& Zabel LLP

Schulte Roth \& Zabel LLP

Schulte Roth \& Zabel LLP

Schulte Roth \& Zabel LLP

Schulte Roth \& Zabel LLP

Schulte Roth \& Zabel LLP

Schulte Roth \& Zabel LLP

Schulte Roth \& Zabel LLP

Schulte Roth \& Zabel LLP

Schulte Roth \& Zabel LLP

Shearman \& Sterling LLP

Shearman \& Sterling LLP

Shearman \& Sterling LLP

Shearman \& Sterling LLP

Shearman \& Sterling LLP

Shearman \& Sterling LLP

Shearman \& Sterling LLP

Shearman \& Sterling LLP

Shearman \& Sterling LLP

Shearman \& Sterling LLP

Shearman \& Sterling LLP

Simpson Thacher \& Bartlett LLP

Simpson Thacher \& Bartlett LLP

Simpson Thacher \& Bartlett LLP

Simpson Thacher \& Bartlett LLP

Simpson Thacher \& Bartlett LLP

Simpson Thacher \& Bartlett LLP

Simpson Thacher \& Bartlett LLP

Simpson Thacher \& Bartlett LLP

Simpson Thacher \& Bartlett LLP

Simpson Thacher \& Bartlett LLP

Simpson Thacher \& Bartlett LLP

Skadden Arps Slate Meagher \& Flom LLP

Skadden Arps Slate Meagher \& Flom LLP

Skadden Arps Slate Meagher \& Flom LLP

Skadden Arps Slate Meagher \& Flom LLP

Skadden Arps Slate Meagher \& Flom LLP

Skadden Arps Slate Meagher \& Flom LLP

\begin{tabular}{|c|c|}
\hline 2003 & 900000 \\
\hline 1993 & 610000 \\
\hline 1994 & 655000 \\
\hline 1995 & 675000 \\
\hline 1996 & 745000 \\
\hline 1997 & 865000 \\
\hline 1998 & 825000 \\
\hline 1999 & 1050000 \\
\hline 2000 & 1210000 \\
\hline 2001 & 1680000 \\
\hline 2002 & 1740000 \\
\hline 2003 & 1840000 \\
\hline 1993 & 400000 \\
\hline 1994 & 420000 \\
\hline 1995 & 480000 \\
\hline 1996 & 510000 \\
\hline 1997 & 600000 \\
\hline 1998 & 660000 \\
\hline 1999 & 740000 \\
\hline 2000 & 915000 \\
\hline 2001 & 965000 \\
\hline 2002 & 1025000 \\
\hline 2003 & 1080000 \\
\hline \multicolumn{2}{|l|}{1993} \\
\hline \multicolumn{2}{|l|}{1994} \\
\hline \multicolumn{2}{|l|}{1995} \\
\hline 1996 & 610000 \\
\hline 1997 & 670000 \\
\hline 1998 & 725000 \\
\hline 1999 & 825000 \\
\hline 2000 & 875000 \\
\hline 2001 & 950000 \\
\hline 2002 & 1090000 \\
\hline 2003 & 1540000 \\
\hline 1993 & 590000 \\
\hline 1994 & 625000 \\
\hline 1995 & 595000 \\
\hline 1996 & 815000 \\
\hline 1997 & 920000 \\
\hline 1998 & 1045000 \\
\hline 1999 & 1135000 \\
\hline 2000 & 1350000 \\
\hline 2001 & 950000 \\
\hline 2002 & 1275000 \\
\hline 2003 & 1215000 \\
\hline 1993 & 925000 \\
\hline 1994 & 930000 \\
\hline 1995 & 1110000 \\
\hline 1996 & 1155000 \\
\hline 1997 & 1285000 \\
\hline 1998 & 1495000 \\
\hline 1999 & 1655000 \\
\hline 2000 & 1740000 \\
\hline 2001 & 1690000 \\
\hline 2002 & 1845000 \\
\hline 2003 & 1940000 \\
\hline 1993 & 690000 \\
\hline 1994 & 820000 \\
\hline 1995 & 885000 \\
\hline 1996 & 990000 \\
\hline 1997 & 1290000 \\
\hline 1998 & 1380000 \\
\hline
\end{tabular}




\section{APPENDIX D-Continued}

\begin{tabular}{|c|c|c|}
\hline Skadden Arps Slate Meagher \& Flom LLP & 1999 & 1600000 \\
\hline Skadden Arps Slate Meagher \& Flom LLP & 2000 & 1600000 \\
\hline Skadden Arps Slate Meagher \& Flom LLP & 2001 & 1565000 \\
\hline Skadden Arps Slate Meagher \& Flom LLP & 2002 & 1605000 \\
\hline Skadden Arps Slate Meagher \& Flom LLP & 2003 & 1600000 \\
\hline Stroock \& Stroock \& Lavan LLP & 1993 & 490000 \\
\hline Stroock \& Stroock \& Lavan LLP & 1994 & 495000 \\
\hline Stroock \& Stroock \& Lavan LLP & 1995 & 485000 \\
\hline Stroock \& Stroock \& Lavan LLP & 1996 & 500000 \\
\hline Stroock \& Stroock \& Lavan LLP & 1997 & 560000 \\
\hline Stroock \& Stroock \& Lavan LLP & 1998 & 595000 \\
\hline Stroock \& Stroock \& Lavan LLP & 1999 & 630000 \\
\hline Stroock \& Stroock \& Lavan LLP & 2000 & 685000 \\
\hline Stroock \& Stroock \& Lavan LLP & 2001 & 785000 \\
\hline Stroock \& Stroock \& Lavan LLP & 2002 & 800000 \\
\hline Stroock \& Stroock \& Lavan LLP & 2003 & 920000 \\
\hline Sullivan \& Cromwell LLP & 1993 & 1275000 \\
\hline Sullivan \& Cromwell LLP & 1994 & 1185000 \\
\hline Sullivan \& Cromwell LLP & 1995 & 1310000 \\
\hline Sullivan \& Cromwell LLP & 1996 & 1330000 \\
\hline Sullivan \& Cromwell LLP & 1997 & 1450000 \\
\hline Sullivan \& Cromwell LLP & 1998 & 1645000 \\
\hline Sullivan \& Cromwell LLP & 1999 & 1790000 \\
\hline Sullivan \& Cromwell LLP & 2000 & 1715000 \\
\hline Sullivan \& Cromwell LLP & 2001 & 1670000 \\
\hline Sullivan \& Cromwell LLP & 2002 & 1720000 \\
\hline Sullivan \& Cromwell LLP & 2003 & 1900000 \\
\hline Thacher Proffitt \& Wood LLP & 1993 & \\
\hline Thacher Proffitt \& Wood LLP & 1994 & \\
\hline Thacher Proffitt \& Wood LLP & 1995 & \\
\hline Thacher Proffitt \& Wood LLP & 1996 & \\
\hline Thacher Proffitt \& Wood LLP & 1997 & \\
\hline Thacher Proffitt \& Wood LLP & 1998 & 415000 \\
\hline Thacher Proffitt \& Wood LLP & 1999 & 480000 \\
\hline Thacher Proffitt \& Wood LLP & 2000 & 480000 \\
\hline Thacher Proffitt \& Wood LLP & 2001 & 475000 \\
\hline Thacher Proffitt \& Wood LLP & 2002 & 640000 \\
\hline Thacher Proffitt \& Wood LLP & 2003 & 810000 \\
\hline Thelen Reid \& Priest LLP & 1993 & \\
\hline Thelen Reid \& Priest LLP & 1994 & \\
\hline Thelen Reid \& Priest LLP & 1995 & \\
\hline Thelen Reid \& Priest LLP & 1996 & \\
\hline Thelen Reid \& Priest LLP & 1997 & \\
\hline Thelen Reid \& Priest LLP & 1998 & 405000 \\
\hline Thelen Reid \& Priest LLP & 1999 & 465000 \\
\hline Thelen Reid \& Priest LLP & 2000 & 500000 \\
\hline Thelen Reid \& Priest LLP & 2001 & 560000 \\
\hline Thelen Reid \& Priest LLP & 2002 & 510000 \\
\hline Thelen Reid \& Priest LLP & 2003 & 555000 \\
\hline Wachtell Lipton Rosen \& Katz & 1993 & 1350000 \\
\hline Wachtell Lipton Rosen \& Katz & 1994 & 1400000 \\
\hline Wachtell Lipton Rosen \& Katz & 1995 & 1595000 \\
\hline Wachtell Lipton Rosen \& Katz & 1996 & 1390000 \\
\hline Wachtell Lipton Rosen \& Katz & 1997 & 2200000 \\
\hline Wachtell Lipton Rosen \& Katz & 1998 & 3105000 \\
\hline Wachtell Lipton Rosen \& Katz & 1999 & 3385000 \\
\hline Wachtell Lipton Rosen \& Katz & 2000 & 3285000 \\
\hline Wachtell Lipton Rosen \& Katz & 2001 & 3165000 \\
\hline Wachtell Lipton Rosen \& Katz & 2002 & 2920000 \\
\hline Wachtell Lipton Rosen \& Katz & 2003 & 2585000 \\
\hline Weil Gotshal \& Manges LLP & 1993 & 745000 \\
\hline Weil Gotshal \& Manges LLP & 1994 & 700000 \\
\hline
\end{tabular}




\section{APPENDIX D-Continued}

\begin{tabular}{|c|c|c|}
\hline Weil Gotshal \& Manges LLP & 1995 & 705000 \\
\hline Weil Gotshal \& Manges LLP & 1996 & 735000 \\
\hline Weil Gotshal \& Manges LLP & 1997 & 805000 \\
\hline Weil Gotshal \& Manges LLP & 1998 & 890000 \\
\hline Weil Gotshal \& Manges LLP & 1999 & 980000 \\
\hline Weil Gotshal \& Manges LLP & 2000 & 1025000 \\
\hline Weil Gotshal \& Manges LLP & 2001 & 1130000 \\
\hline Weil Gotshal \& Manges LLP & 2002 & 1300000 \\
\hline Weil Gotshal \& Manges LLP & 2003 & 1505000 \\
\hline White \& Case LLP & 1993 & 530000 \\
\hline White \& Case LLP & 1994 & 555000 \\
\hline White \& Case LLP & 1995 & 565000 \\
\hline White \& Case LLP & 1996 & 565000 \\
\hline White \& Case LLP & 1997 & 625000 \\
\hline White \& Case LLP & 1998 & 665000 \\
\hline White \& Case LLP & 1999 & 725000 \\
\hline White \& Case LLP & 2000 & 775000 \\
\hline White \& Case LLP & 2001 & 865000 \\
\hline White \& Case LLP & 2002 & 935000 \\
\hline White \& Case LLP & 2003 & 1010000 \\
\hline Willkie Farr \& Gallagher LLP & 1993 & 720000 \\
\hline Willkie Farr \& Gallagher LLP & 1994 & 740000 \\
\hline Willkie Farr \& Gallagher LLP & 1995 & 760000 \\
\hline Willkie Farr \& Gallagher LLP & 1996 & 915000 \\
\hline Willkie Farr \& Gallagher LLP & 1997 & 900000 \\
\hline Willkie Farr \& Gallagher LLP & 1998 & 955000 \\
\hline Willkie Farr \& Gallagher LLP & 1999 & 1100000 \\
\hline Willkie Farr \& Gallagher LLP & 2000 & 1015000 \\
\hline Willkie Farr \& Gallagher LLP & 2001 & 1170000 \\
\hline Willkie Farr \& Gallagher LLP & 2002 & 1295000 \\
\hline Willkie Farr \& Gallagher LLP & 2003 & 1410000 \\
\hline Wilson, Elser, Moskowitz, Edelman \& Dicker LLP & 1993 & 405000 \\
\hline Wilson, Elser, Moskowitz, Edelman \& Dicker LLP & 1994 & 275000 \\
\hline Wilson, Elser, Moskowitz, Edelman \& Dicker LLP & 1995 & 320000 \\
\hline Wilson, Elser, Moskowitz, Edelman \& Dicker LLP & 1996 & 330000 \\
\hline Wilson, Elser, Moskowitz, Edelman \& Dicker LLP & 1997 & 305000 \\
\hline Wilson, Elser, Moskowitz, Edelman \& Dicker LLP & 1998 & 290000 \\
\hline Wilson, Elser, Moskowitz, Edelman \& Dicker LLP & 1999 & 270000 \\
\hline Wilson, Elser, Moskowitz, Edelman \& Dicker LLP & 2000 & 270000 \\
\hline Wilson, Elser, Moskowitz, Edelman \& Dicker LLP & 2001 & 370000 \\
\hline Wilson, Elser, Moskowitz, Edelman \& Dicker LLP & 2002 & 605000 \\
\hline Wilson, Elser, Moskowitz, Edelman \& Dicker LLP & 2003 & 690000 \\
\hline
\end{tabular}

\section{APPENDIX E QUESTIONS FOR GP PARTNERS}

1. Has your firm discussed becoming an LLP?

2. What were the reasons asserted in favor of remaining a GP?

3. What were the reasons (other than limited liability) asserted in favor of LLP?

4. Was there an age division?

a. I.e., did older partners favor the status quo more than younger ones?

5. Do you think that you'll eventually move to become an LLP?

6. Was there any talk of redoing the partnership agreement to reflect higher profits for high-risk/high-return partners if you moved to LLP? 

ture?

7. Does your firm have a lock-step partner compensation struc-

\section{APPENDIX F QUESTIONS FOR LLP PARTNERS}

1. Your firm didn't take advantage of the LLP statute right away. In fact it took you years to make the LLP filing. What took so long?

OR

Unlike many New York firms, your firm opted to become an LLP fairly quickly after the statute became effective. Why was the choice so easy for you? Why do you think other firms struggled with the decision and your firm did not?

2. What were the primary arguments made against the LLP filing?

a. Monitoring?

b. Collegiality?

c. Signaling?

d. Intra-firm economics?

e. Were there age differences in these arguments? i.e. did older partners favor the traditional GP structure more than younger partners did?

3. What were the factors that caused the arguments in favor of LLP to finally win out?

4. Has your firm had any regrets about the choice to become an LLP?

a. Has it altered your practice or relations with clients in any way?

b. Has it altered relations among the partners in any way?

c. Has it altered relations with your insurance company in any way?

5. IF APPLICABLE-I notice that you filed at the same time as [similar firms]. Was that a conscious decision? Did their decision to file affect your decision in any way?

6. Does your firm have a lock-step partnership structure? 
